392850

\title{
Publications on Maglev Technologies
}

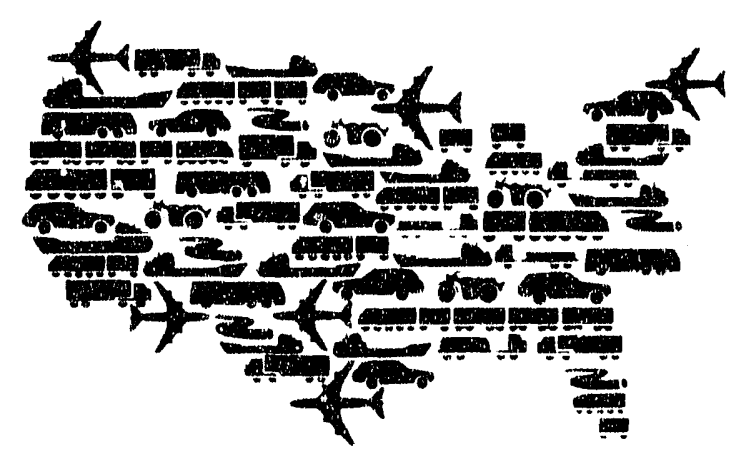

Center for Transportation Research Argonne National Laboratory

Operatod by The Univarsity of Chicatgo, undor Contract i 31-109-Eng-38, for the United States Department of Energy 


\section{Argonne National Laboratory}

Argonne National Laboratory, with facilities in the states of Illinois and Idaho, is owned by the United States govemment, and operated by the University of Chicago under the provisions of a contract with the Department of Energy.

This technical memo is a product of Argonne's Energy Systems (ES)

Division. For information on the division's scientific and engineering activities, contact:

Director, Energy Systems Division

Argonne National Laboratory

Argonne, Illinois 60439-4815

Telephone (708) 252-3724

Presented in this technical memo are preliminary results of ongoing work or work that is more limited in scope and depth than that described in formal reports issued by the ES Division.

\section{Disclaimer}

This report was prepared as an account of work sponsored by an agency of the United States Government. Neither the United States Govemment nor any agency thereof, nor any of their employees, makes any warranty, express or implied, or assumes any legal liability or responsibility for the accuracy, completeness, or usefulness of any information, apparatus, product, or process disclosed, or represents that its use would not infringe privately owned rights. Reírence herein to any specific cummercial product, process, or service by trade name, trademark, manufacturer, or otherwise, does not necessarily constitute or imply its endorsement, recommendation, or favoring by the United States Govemment or any agency thereof. Thie views and opinions of authors expressed herein do not necessarily state or reflect those of the United States Govemment or any agency thereof.

Available to DOE and DOE contractors from the Office of Scientific and Technical Information, P.O. Box 62 . Oak Ridge, TN 37831; prices available from (615) 576-8401, FTS 626-8401.

Available to the public from the National Technical Information Service, U.S. Department of Commerce, 5285 Port Fioyal Road, Springfield, VA 22161. 


\section{Publications on Maglev Technologies}

by J.L. He, H.T. Coffey, D.M. Rote, and Z. Wang

Center for Transportation Research, Energy Systems Division,

Argonne National Laboratory, 9700 South Cass Avenue, Argonne, Illinois 60439

December 1991

Work sponsored by the Illinois Department of Commerce and Community Affairs, Office of Technology Advancement and Development; the U.S. Army Corps of Engineers; and the Federal Railroad Administration 


\section{Contents}

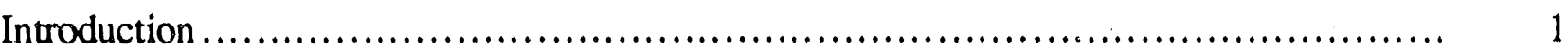

1 Economic and Technical Feasibilities..................................................... 1.1

2 Concepts, Principles, and Potertial Applications ................................ 2.1

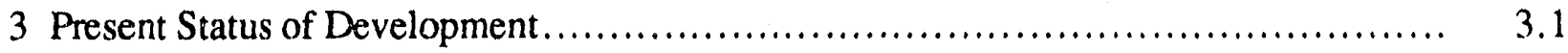

4 Suspension and Levitation Techniques................................................... 4.1

5 Linear Propulsion Techniques............................................................ 5.1

6 Integrated Magnetic Suspension, Propulsion, and Guidance Systems................. 6.1

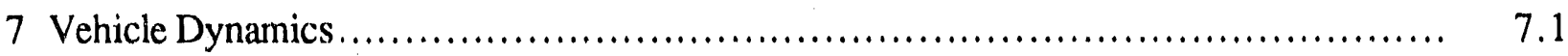

8 System Control and Simulations............................................ 8.1

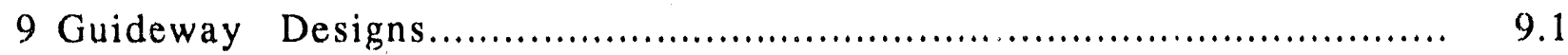

10 Superconducting Magnets and Cryogenic Technologies........................... 10.1

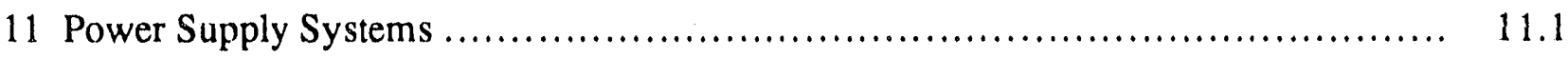

12 Numerical Analysis......................................................... 12.1

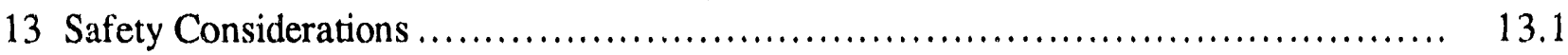

14 Electromagnetic Field Shielding................................................... 14.1

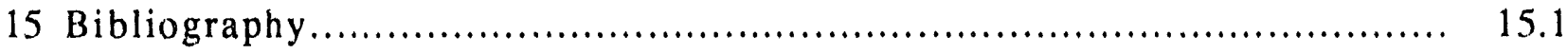

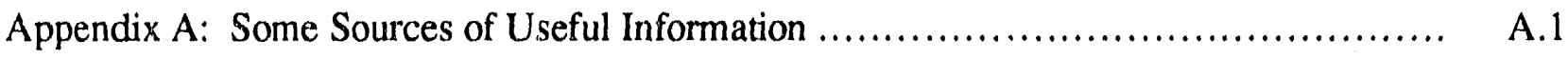

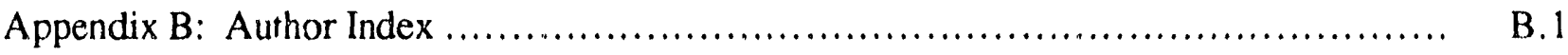




\title{
Publications on Maglev Technologies
}

by

\author{
J.L. He, H.T. Coffey, D.M. Rote, and Z. Wang
}

\section{Introduction}

Magnetically levitated passenger-transportation vehicles, using attractive and repulsive magnetic forces, are currently in the development or prototype-revenue stages in Japan and Germany. The basic principles of these technolugies have been understood for several decades, but their practical applications awaited advances in high-power electronic devices, modern controls, superconducting magnets, and improvements in our transportation infrastructures.

A considerable amount of work was devoted to magnetic-levitation (maglev) transportation systems in the late 1960s and the 1970s. Detailed development was sustained primarily in Germany and Japan. The literature on the subject spans more than 20 years.

This listing of publications was begun as the initial phase of a design study for a maglev development facility sponsored by the State of Illinois. The listing has been continually updated under programs sponsored by the Federal Railroad Administration (FRA) and the U.S. Army Corps of Engineers (COE). In 1991, the National Maglev Initiative, managed by the FRA, COE, and the U.S. Department of Energy, issued 27 contracts for the study of technical issues related to maglev and four contracts for the definition of maglev systems. In December 1991, the Intermodal Surface Transportation Efficiency Act was enacted, mandating the development of a U.S.-designed maglev system in a six-year period. This listing is offered as an aid to those working on these projects, to help them locate technical papers on relevant technologies.

The design and installation of a maglev transportation system will require the efforts of workers in many disciplines, from electronics to economics to safety. Accordingly, the references have been grouped in 14 different sections to expedite review of the listing. In many cases, the references are annotated to indicate the general content of the papers. Abstracts are not available. Appendix A provides a list of information services from which the listed documents might be obtained. Appendix B constitutes an author index, provided to assist the reader in finding the work of particular individuals. 


\section{Economic and Technical Feasibilities}

TECHNICAL FEASIBILITY OF MAGNETIC LEVITATION AS A SUSPENSION SYSTEM FOR HIGH-SPEED GROUND TRANSPORTATION VEHICLES

Davis, L. C.; Reitz, J. R.; Wilkie, D. F.; Borcherts, R. H.

U. S. Dept. of Transp., Federal Railway Administration, Rep. FRA-RT-72-40, Feb. 1972

THE FEASIBILITY OF MAGNETICALLY LEVITATING HIGH-SPEEU GROUND VEHICLES

Coffey, H. T.; Chilton, F; Hopple, L.O.

Prepared by Stanford Research Inst. for U.S. DOT, FRA, Rep. FRA-RT-72-39, Feb. 1972

NTIS (PB-210505)

MAGNETIC SUSPENSION FOR GUIDED TRANSPORT VEHICLES

Bunting, P.M.

Transportation Planning \& Technology, Vol. 1, No. 1, April 1972, pp. 49-74

(TRIS No. 242247 DA) (Survey and introductions)

PROBLEMS ARISING IN CONNECTION WITH THE USE OF SUPERCONDUCTOR COILS IN A

PASSENGER TRANSPORT SYSTEM

Autruffe, $\mathrm{H}$.

Laboratorio Naz del Com Naz per l'Energ Nucl, Frascati, Itai', pp. 468-476

(TRIS No. 136416 DA)

AN ECONOMIC ASSESSMENT OF HIGH SPEED TRANSPORTATION IN THE CANADIAN CORRIDOR Boon, C. J.; Eastham, A. R.; Schwier, C.

The Second Int. St'minar on Superconductive Magnetic Levitated Train, Mlyazaki, Japan, Nov. 1982, pp. $142-151$

(Economic evaluation with data analysis)

SUBSTITUTION EFFECTS OF MAGLEV ON THE FRANKFURT-PARIS ROUTE

Schmitt, A.

Electr. Veh. Dev., No. 17, Summer 1983, pp. 14-15, 20

(NTIS No. 84-03 06459)

ESSENTIAL TECHNIQUES IN MAGLEV TRANSPORTATION

Sato, $Y$.; Hasegawa, $Y$.; Ishizuka, $H$.

Q. Rep. Railw. Tech. Res. Inst. (Jpn), Vol.25, No.1, 1984, pp. 13-18

(NTIS No. 84-09 07680)

HIGH-SPEED RAIL SYSTEMS IN THE UNITED STATES

Bondada, A.; Dondiego, R. L.; Harrison, J.; Kikuchi, S.; et al.

J. Transp. Eng., Vol.111, No.2, March 1985, pp. 79-94

(NTIS No. 85-04 03953)

GENEFIAL SURVEY OF THE POSSIBLE APPLICATIONS AND DEVELOPMENT TENDENCIES OF MAGNETIC LEVITATION TECHNOLOGY

Rogg, D.

IEEE Trans. Magn., Vol. Mag-20, No.5, Sept. 1984, pp. 1696-1707

(NTIS No. 85-07 10176)

STATUS, PROSPECT, AND FACTORS AFFECTING U.S. DEVELOPMENT OF MAGLEV

TRANSPORTATION TECHNOLOGY

Norris, G. A.

SAE Tech. paper Ser. 841735, 1984, 25pp.

(NTIS No. 86-07 00088) 
A FEASIBILITY STUDY ON ELECTROMAGNETIC SYSTEMS AND LINEAR MOTORS IN JAPAN Iguchi, $M$.

Proc., Int. Conf. Maglev Transport '85, Sept. 17-19, 1985, Keidanren Kaikan, Tokyo, Japan, Publ. by IEE, Japan, pp. 303-310

(Cost evaluations)

\section{FEASIBILITY STUDIES FOR MAGLEV CONNECTIONS IN GERMANY}

Polifka, F.

Proc., Int. Conf. Maglev Transport '85, Sept. 17-19, 1985, Keidanren Kaikan, Tokyo, Japan, Publ. by IEE, Japan, pp. 289-293

(A plan of feasibility studies)

THE TRANSRAPID MAGLEV SYSTEM - PROSPECTS OF APPLICATION

Hebler, $\mathrm{H}$.

Proc., Int. Conf. Maglev Transport '85, Sept. 17-19, 1985, Keidanren Kaikan, Tokyo, Japan, Publ. by IEE, Japan, pp. 285-288

(Feasibility studies)

DEMAND POTENTIALS FOR MAGLEV PASSENGER TRANSPORT IN EUROPE

Eberlein, $D$.

Proc., Int. Cont. Maglev Transport '85, Sept. 17-19, 1985, Keidanren Kaikan, Tokyo, Japan, Publ. by IEE, Japan, pp. 277-284

(Market forecast)

THE TRANSRAPID MAGLEV SYSTEM - ITS PROSPECTS FOR APPLICATION

Hessler, H., and Wackers, M.

Proc., Int. Cont. Maglev and Linear Drives, May 14-16, 1986, Vancouver, B. C., Canada, Publ. by IEEE, 86CH2276-4, pp. 257-267

(General concept, feasibility studies, and future prospects)

TGV OR MAGLEV-EUROPEAN EXPERIENCE AND NORTH AMERICAN CHOICE

Blumstein, J. C., and Brand, N. M.

Proc., Int. Conf. Maglev and Linear Drives, May 14-16, 1986, Vancouver, B. C., Canada, Publ. by IEEE, 86CH2276-4, pp. 21-25

(Feasibility studies)

MAGLEV: THE URBAN MARKET

Barber, J. B.

Proc., Int. Conf. Maglev and Linear Drives, May 14-16, 1986, Vancouver, B. C., Canada, Publ. by IEEE, 86CH2276-4, pp. 13-20

(Market forecast)

FEASIBILITY OF THE MAGLEV TRANSPORT IN URBAN AND REGIONAL APPLICATIONS

Masada, E., and Tamura, M.

Proc., Int. Cont. Maglev and Linear Drives, May 14-16, 1986, Vancouver, B. C., Canada, Publ. by IEEE, $86 \mathrm{CH} 2276-4$, pp. $7-11$

(Feasibility studies)

SUPER-SPEED GROUND TRANSPORTATION SYSTEM - LAS VEGAS/SOUTHERN CALIFORNIA CORRIDOR, PHASE II: MAGLEV TECHNOLOGY ASSESSMENT

CIGGT

Canadian Institute Guided Ground Transport, Rep. CIGGT 86-09, Queen's Univ., Kingston, Ontario, Canada, July 1986.

LAS VEGAS TO SOUTHERN CALIFORNIA SS-GTS, PHASE II: ORGANIZATIONALIFINANCIAL ANALYSIS

Harman, R. J.; \& Associates

Prepared for the City of Las Vegas, Nev., March 1987 
HIGH-SPEED GROUND TRANSPORTATION TECHNOLOGIES FOR THE LAS VEGAS - SOUTHERN CALIFORNIA CORRIDOR

Boon, C. J.; Hayes, W. F.; Schwier, C.; Eastham, A. R.; Campbell, T. I.; Dawson, G. E.

Proc., Int. Conf. Maglev and Linear Drives, Las Vegas, Nev., USA, May 19-21, 1987, Publ. by IEEE, 87CH2443-0, pp. 227-240

(System feasibility studies)

PATRONAGE ANALYYSIS AND FORECAST FOR MAGLEV SERVICE BETWEEN LAS VEGAS AND SOUTHERN CALIFORNIA

Hamburg, J. R., and Keith, R. W.

Proc., Int. Conf. Maglev and Linear Drives, Las Vegas, Nev., USA, May 19-21, 1987, Publ. by IEEE, 87CH2443-0, pp. 219-225

(Market forecast)

THE TRANSRAPID MAGLEV SYSTEM: ITS APPLICATION IN THE RHEIN/MAIN - RHEIN/RLIHR CORRIDOR IN THE FEDERAL REPUBLIC OF GERMANY

Alexy, R.

Proc., Int. Conf. Maglev and Linear Drives, Las Vegas, Nev., USA, May 19-21, 1987, Publ. by IEEE, 87CH2443-0, pp. 195-204

(Potential applications and feasibilities)

APPLICATION FIELD STUDIES

Ribbentrop, R.

Proc., Int. Cont. Maglev and Linear Drives, Las Vegas, Nev., USA, May 19-21, 1987, Publ. by IEEE, 87CH2443-0, pp. 189-194

(Feasibility studies)

THE LAS VEGAS/M-BAHN MAGNETICALLY LEVITATED PEOPLE MOVER SYSTEM

Huss, H.W.

Proc., Int. Conf. Maglev and Linear Drives, Las Vegas, Nev., USA, May 19-21, 1987, Publ. by IEEE, 87CH2443-0, pp.125-128

(Prospect)

DUST FREE WAFER TRANSPORTATION SYSTEM FOR SEMICONDUCTOR PLANT - AN APPLICATION OF NEW MAGLEV TECHNOLOGY

Takagi, S.; Kanda, S.; Azukizawa, T.; Yokoyama, T.

Proc., Int. Conf. Maglev and Linear Drives, Las Vegas, Nev., USA, May 19-21, 1987, Publ. by IEEE, 87CH2443-0, pp. 73-78

WILL MAGLEV EVER GET OFF THE GROUND IN THE U.S.?

Cortes-Comerer, N.

Mech. Eng., Vol. 110, No. 10, Oct. 1988, pp. 58-63

(NTIS No. 89-03 01495)

HSR COST ESTIMATING TECHNIQUES IN PENNSYLVANIA

Schmelz, R. E.

J. Transp. Eng., Vol. 115, No. 1, Jan. 1989, pp. 84-94

(NTIS No. 89-04 02295)

MAGLEV: AN EMERGING TRANSPORTATION TECHNOLOGY TO MEET AN IMMINENT

TRANSPORTATION NEED

Uher, P. A.

Rail Eng. Int., Vol. 18, No. 1, 1989, pp. 5-8

(NTIS No. 89-08 02025) 
MAGLEV VEHICLES AND SUPERCONDUCTOR TECHNOLOGY: INTEGRATION OF HIGH-GROUND TRANSPORTATION INTO THE AIR TRAVEL SYSTEM

Johnson, L. R.; Rote, D. M.; Hull, J. R.; Coffey, H. T.; Daley, J. G.; Giese, R.F

Center for Transp. Res., Argonne National Lab., Rep. No. ANL/CNSV-67, April 1989, 121 pp., aviulable from NTIS

APPLICATION OF TRANSRAPID MAGLEV IN MEDIUM/SHORT-DISTANCE ROUTES IN JAPAN Otsuka, K.; Hoshino, A.; Kretzschmar, R.

Proc., 11th Int. Conf. Magnetically Levitated Syst. and Linear Drives, July 7-11, 1989, Yokohama, Japan, Publ. by IEE Jpn., pp.129-133

APPLICATION OF TRANSRAPID MAGLEV IN LONG-DISTANCE ROUTES IN JAPAN Hoshino, A.; Otsuka, K.; Kretzschmar, R.

Proc., 11 th Int. Conf. Magnetically Levitated Syst. and Linear Drives, July 7-11, 1989, Yokohama, Japan, Publ. by IEE Jpn., pp. 123-127

TECHNICAL APPLICATION OF THE MAGI .EV HIGH-SPEED TRANSPORT SYSTEM: THE OPERATORS POINT OF VIEW

Polifka, $F$.

Proc., 11th Int. Conf. Magnetically Levitated Syst. and Linear Drives, July 7-11, 1989, Yokohama, Japan, Publ. by IEE Jpn., pp. 1C5-109

\section{SPECIFIC ASPECTS OF MAGLEV LINKS IN THE DIFFERENT TYPES OF CONNECTION WITH AIR} TRANSPORTATION

Willigens, J. M., and Kraus, H. G.

Pruc., 11th Int. Cont. Magnetically Levitated Syst. and Linear Drives, July 7-11, 1989, Yokohama, Japan, Publ. by IEE Jpn., pp. 63-72

THE U.S. MARKET FOR HIGH-SPEED MAGLEV VEHICLES

Rote, D. M.; Coffey, H. T.; Johnson, L. R.; Daniels, E.

Proc., $1 \mathrm{ith}$ Int. Cont. Magnetically Levitated Syst. and Linear Drives, July 7-11, 1989, Yokohama, Japan, Publ. by IEE Jpn., pp. 53-61

SELECTION OF ROUTES FOR A MAGLEV HIGH-SPEED TRANSPORT SYSTEM IN THE FEDERAL REPUBLIC OF GERMANY FROM A FUTURE OPERATOR'S POINT OF VIEW

Ribbentrop, $R$.

Proc., 11 th Int. Conf. Magnetically Levitated Syst. and Linear Drives, July 7-11, 1989, Yokohama, Japan, Publ. by IEE Jpn., pp. 47-52

APPLICATION OF THE MAGNETIC LEVITATION TRAIN IN THE FEDERAL REPUBLIC OF GERMANY Raschbichler, H. G., and Wackers, M.

Proc., 11th Int. Conf. Magnetically Levitated Syst. and Linear Drives, July 7-11, 1989, Yokohama, Japan, Publ. by IEE Jpn., pp. 37-46

\section{THE LINEAR EXPRESS}

Dol, T.; Seki, A.; Uno, M.

Proc., 11th Int. Conf. Magnetically Levitated Syst. and Linear Drives, July 7-11, 1989, Yokohama, Japan, Publ. by IEE Jpr., pp. 23-27

\section{OPPORTUNITIES AND PROSPECTS FOR MAGLEV IN NORTH AMERICA}

Eastharn, T. R., and Cotfey, H. T.

Proc., 11th Int. Conf. Magnetically Levitated Syst. and Linear Drives, July 7-11, 1989, Yokohama, Japan, Publ. by IEE Jpn., pp. 19-22

PUTTING MAGLEV ON TRACK

Johnson, L.R.

Issues in Science and Technology, Vol. VI, No. 3, 1990, National Academy of Sciences, pp. 71-75 


\title{
2 Concepts, Principles, and Potential Applications
}

\author{
THE MAGNETIC RAILROAD : A NEW FORM OF TRANSPORT \\ Powell, J. R. \\ American Soc. of Mech. Eng. Railroad Conf., April 1963, Pap. No. 63-RR4 \\ HIGH-SPEED TRANSPORT BY MAGNETICALLY SUSPENDED TRAINS \\ Powell, J. R., and Danby, G. T. \\ American Soc. of Mech. Eng. Winter Annual Meeting, New York, N.Y., Nov. 1966, \\ Paper No. 66-WAVRR-5
}

A 300-MPH MAGNETICALLY SUSPENDED TRAIN

Powell, J. R., and Danby, G.T.

Mechanical Eng., Vol. 89, Nov. 1967, pp. 30-35

THE HYPERVELOCITY ROCKET SLED

Barbee, T. W., et al.

Stanford Research Inst., Final Rep., Project PMU 7014, July, 1968

(Design analysis)

ELECTROMAGNETIC INDUCTIVE SUSPENSION AND STABILIZATION SYSTEM FOR A GROUND VEHICLE

Powell, J. R., and Danby, G. T.

U. S. Patent, 3,470,828, filed Nov. 21, 1967, Granted Oct. 7, 1969

MAGNETICALLY SUSPENDED TRAINS: THE APPLICATION OF SUPERCONDUCTORS TO HIGH. SPEED TRANSPORT

Powell, J. R., and Danby, G. T.

Cryogenics and Industrial Gases, pp. 19-24, Oct. 1969

MAGNETIC LEVITATION: TOMORROW'S TRANSPORTATION

Chilton, F., and Coftey, H. T.

Proc. Helium Society Symp., Washington, D. C., 1971

MAGNETIC LEVITATION FOR TOMORROW'S TRANSPORTATION

Coffey, H. T.; Chilton, F.; Hoppie, L. O.

Advances in Cryogenic Technology, 4, 1971, R. W. Vance, ed., Xyzyx Information Corp., Los Angeles, Calis, , pp. 275-298

ROAD-USER PERCEPTION

Kyotani, $Y$.

Jpn. Railw. Eng., Vol. 13, No. 4, 1972, pp. 3-9

(TRIS No. 081216 DA)

MAGNEPLANE: GUIDED ELECTROMAGNETIC FLIGHT

Kolm, H. H., and Thornton, R. D.

Proc. Pap. 5th Int. Appl. Superconduct. Cont., IEEE Publ. No. 72CH0682-5-TABSC, May 1-3, 1972 pp. 76-85

(NTIS No. 74-02 02958)

MAGNETIC LEVITATION OF HIGH SPEED GROUND VEHICLES

Coffey, H.T.; Chilton, F.; Hopple, L. O

Proc. Pap. 5 th Int. Appl. Superconduct. Conf., IEEE Publ. No. 72CH0682-5-TABSC, May 1-3, 1972, pp. 62-75,

(NTIS NO. 74-02 02959) 
TRAINS OF THE FUTURE

Staehell, G. A.

Proc., 37th Annual Proceeding of the Railway Fuel and Operating Otficers Association, 1973, $10 \mathrm{pp}$. (TRIS No. 054603 DA)

ELECTROMAGNETIC FLIGHT

Kolm, H. H. and Thornton, R. D.

Scientific American, Vol. 229, No. 4, Oct. 1973, pp. 17-25

SRI MAGNETIC SUSPENSION STUDIES FOR HIGH-SPEED VEHICLES

Coffey, H. T.

Advances in Cryogenic Engineering, Vol. 19, Plenum Press, New York, 1974, pp. 137-153

FLYING LAIND VEHICLES USING SUPERCONDUCTING MAGNETS

Rhodes, R. G.; Mulhall, B. E.; Abel, E.

Proc. Paper, Int. Hovering Craft, Hydrofoll and Adv. Transit. Syst. Conf., Brighton, Susssex, England, May 13-16, 1974, pp. 157-166

(TRIS No. 132946 DA)

U.S. DEPARTMENT OF TRANSPORTATION PROGRAM IN MAGNETIC SUSPENSION (REPULSION CONCEPT)

Rettz, J.R., and Borcherts, R. H.

IEEE Trans. Magn., Vol. MAG-11, No. 2, March 1975, pp. 615-618

(NTIS No. 75-09 03599)

MAGNETICALLY LEVITATED VEHICLES

Railway Engineer, Vol. 2, No. 2, March 1977, pp. 49-51

(TRIS No. 153799 DA) (Introduction)

MAGNETIC LEVITATION

Chartered Mechanical Engineer, Vol. 25, No. 11, Dec. 1978, p. 19

(TRIS No. 194146)

CONCEPTUAL DESIGN STUDY OF A HIGH SPEED MAGLEV GUIDED GROUND TRANSPORTATION SYSTEM

Hayes, W. F.

Natl. Res. Counc., Can. Div. Mech. Eng., Q. Bull., No. 3, 1979, pp. 35-37

(NTIS No. 80-07 01877)

MAGNETIC WHEEL IN THE SUSPENSION OF HIGH-SPEED GROUND TRANSPORTATION VEHICLES

Goltzein, E.; Meisinger, R.; Miller, L.

IEEE Trans. Veh. Technol., Vol. Vi-29, No.1, Feb. 1980, pp. 17-23

(NTIS No. 80-09 01831)

PASSENGER CARRYING VEHICLES USING CONTROLLED DC MAGNETS

Jayawant, B. V.

Proc. Int. Conf. Cybern. Soc., Cambridge, Mass., Oct. 8-10, 1980, pp. 1013-1017

(NTIS No. 81-05 04161)

WHATEVER HAPPENED TO MAGLEV?

IEEE Spectrum, Aug. 1982, 1p.

(TRIS No. 372007)

THE USE OF MAGNETIC ATTRACTION AND LEVITATION FOR THE LANDING OF AIRCRAFT ON A CARRIER

Wipf, S. L.

The Second Int. Seminar on Superconductive Magnetic Levitated Train, Miyazaki, Japan, Nov. 1982, pp. 152-159 (New application) 


\section{SAGA OF MAGLEV}

Money, L. J.

Transp. Res. Part A, Vol. 18A, No.4, July 1984, pp. 333-341

(NTIS No. 85-04 01447)

FLYING LOW MAGNETICALLY

Sinha, P. K.

Electron Power, Vol.30, No.10, Oct. 1984, pp. 797-802

(NTIS No. 85-10 01117)

HIGH SPEED GROUND TRANSPORTATION: SOME CURRENT AND FUTURE ALTERNATIVES

Morita, $\mathrm{T}$.

Technol. Soc., Vol. 6, No.2, 1984, pp. 141-149

(NTIS No. 86-01 05404)

PROPELLING PASSENGERS FASTER THAN A SPEEDING BULLET (MAGLEV R\&D IN FOREIGN COUNTRIES)

Alsher, H.; Boldea, I.; Eastham, A. R.; Iguchi, M.

IEEE Spectrum, Vol. 21, Aug. 1984, pp 57-64

(TRIS No. 469293)

HIGH-SPEED RAIL

Thompson, L. S.

Technology Review, Vol. 89, No. 3, 1986, pp. 41-70

WEST GERMANY OKAYS WORLD'S FIHST COMMERCIAL MAGLEV LINE

New Technol. Week, July 5, 1988, p. 3

MAGLEV

Kyotani, $Y$.

Cryogenic Engineering, Vol. B:21, Nov. 1986, pp. 14-16

(TRIS No. 468825)

RIDING OR FLYING?- TRANSRAPID AND ITS LINKS WITH CAR, RAILWAY, AND AIRCRAFT

Brochure, MVP Versuchs - und Planungsgesellschaft fur Magnetbahnsysteme mGH, Munich, Federal

Republic of Germany, 1985

COMPARATIVE EVALUATION OF TECHNOLOGIES FOR HIGH-SPEED GROUND TRANSPORTATION

Genest, B. A.; Audette, M.; Sanders, D. B.

Transp. Res. Rec. 1023, 1985, pp. 38-48

(NTIS No. 86-03 02648)

FUTURE OF MAGLEV TECHNOLOGY

Pollard, M. G.

Proc. Inst. Civ. Eng.(London), Vol.80, Feb. 1986, pp. 161-178

(NTIS No. 86-05 09000)

MAGLEV: TRANSPORTATION FOR THE 21ST CENTURY

Andrus, G. M., and Gillies, G. 'T.

Civ. Eng. (New York) Vol.57, No.4, April 1987, pp.65-67

(NTIS No. 87-06 02932)

MAGLEV APPROACHES PRACTICAL USE

Tanaka, $\mathrm{H}$.

Japan Railway Engineers' Association

Japanese Railway Eng., Vol. 27, No.1, June 1987, pp. 2-6

(TRIS No. 468377) 
MAGNETIC LEVITATIOII TECHNOLOGY AND ITS DEVELOPMENT POTENTIAL

Weh, $H$.

Proc., 11 th Int. Conf. Magnetically Levitated Syst. and Linear Drives, July 7-11, 1989, Yokohama, Japan, Publ. by IEE Jpn., pp. 1-9

MAGLEV SYSTEM DESIGN CONSIDERATIONS

Coffey, H.T.

Future Transportation Technology Conference and Exposition, Portland, Oregon, Aug. 5-7, 1991

SAE Technical Papers Series 911624

TRANSPORTATION IN THE TWENTY-FIRST CENTURY

Cottey, H.T.

The Nineteenth Annual Illinois Energy Conference, The Fairmont Hotel, Chicago, Illinois, Oct. 11, 1991 


\section{Present Status of Development}

HIGH-SPEED TRANSPORTATION VIA MAGNETICALLY SUPPORTED VEHICLES. A STUDY OF THE MAGNETIC FORCES

Borcherts, R. H., and Reitz, J. R.

Transportation Res., Vol. 5, 197-209, 1971

STUDY OF A MAGNETICALLY LEVITATED VEHICLE

Cotfey, H.T.; Colton, J. D.; Mahrer, K. D.

Stanford Res. Inst., Final Report, Feb 1973, 103 pp., Contract No. DOT-FR-10001

(TRIS No. 047848 DA) (NTIS PB 221696)

SUPERCONDUCTING MAGNET LEVITATION / PROPULSION TEST VEHICLE

Usami, Y.; Kuzuu, T.; Fujie, J.

Q. Rep. Railw. Tech. Res. Inst. (Jpn), Vol. 15, No. 2, 1974, pp. 62-68

(TRIS No. 057857 DA)

AN EVALUIATION OF THE DYNAMICS OF A MAGNETICALLY LEVITATED VEHICLE

Coffey, H. T.; Colton, J.D.; Solinsky, J.C.; Woodbury, J.R.

Prepared by SRI for U.S. DOT, FRA, Report FRA-ORD80-74-41 March 1974

(NTIS No. PB-23667/4GA)

HIGH SPEED RAILWAYS IN JAPAN

Kyotani, $\mathrm{Y}$.

Proc. 5th Int. Cryog. Eng. Cont., Kyoto, Japan, May 7-10, 1974, pp.17-20

(TRIS No. 130901 DA)

HIGH-SPEED MAGLEV STUDIES IN CANADA

Atherton, D. L.

Proc. 5th Int. Cryog. Eng. Conf., Kyoto, Japan, May 7-10, 1974, pp. 46-50

(TRIS No. 130902 DA)

ELECTROMAGNETIC DYNAMIC LEVITATION DEVELOPMENT IN CANADA

Atherton, D. L., and Eastham, A. R.

High Speed Ground Transport. Journal, Vol. 8, No. 2, June 1974, pp. 101-110

(TRIS No. 096106 DA)

CONCEPTUAL DESIGN AND ANALYSIS OF THE TRACKED MAGNETICALLY LEVITATED VEHICLE TECHNOLOGY (TMLV), REPULSION SCHEME, VOL. I, TECHNICAL. STUDIES

Ford Motor Co., Feb. 1975, Final Rept.

Federal Railroad Administration, Report FRA-OR\&D-75-21

(NTIS PB-247931) (Executive summary)

CONCEPTUAL DESIGN AND ANALYSIS OF THE TRACKED MAGNETICALLY LEVITATED VEHICLE TECHNOLOGY PROGRAM (TMLV), REPULSION SCHEME, VOL. II, APPENDIX A-F

Ford Motor Co., Feb. 1975, Final Rept.

Federal Railroad Administration, FRA-OR\&D-75-21A

(NTIS PB-247932) (Executive summary)

CONCEPTUAL DESIGN AND ANALYSIS OF THE TRACKED MAGNETICALLY LEVITATED VEHICLE TECHNOLOGY PROGRAM (TMLV), REPULSION SCHEME, VOL. III, APPENDIX G. 5 DOF COMPUTER PROGRAM

Ford Motor Co., Feb. 1975, Final Rept.

Federal Railroad Administration, FRA-OR\&D-75-21B

(NTIS PB-247933) (Computer programs) 
ANNUAL REPORT OF THE CIGGT. 1974-1975. PART 1: RESEARCH PROGRESS

Law, C. E.

Canadian Inst. of Guided Ground Transport; Rep. No. CIGGT-75-6, Queen's Univ., Kingston, Ontario, Canada

(TRIS No. 145176 DA)

SUPERCONDUCTING MAGNETIC LEVITATION AND LINEAR SYNCHRONOUS MOTOR PROPULSION FOR HIGH SPEED GROUND TRANSPORTATION

Eastham, A. R., Editor

Canadian Inst. of Guided Ground Transport; Rep. No. CIGGT-75-5, Queen's Univ., Kingston, Ontario, Canada, March 1975, 297 pp.

(TRIS No. 141128 DA)

SUPERCONDUCTING MAGLEV AND LSM DEVELOPMENT IN CANADA

Atherton, D. L., and Eastham, A. R.

IEEE Trans. Magn., Vol. MAG-11, No. 2, March 1975, pp. 627-632

(TRIS No. 127628 DA)

UNITED STATES DEPARTMENT OF TRANSPORTATION PROGRAM IN MAGNETIC SUSPENSION (REPULSION CONCEPT)

Reitz, J. R., and Borcherts, R. H.

IEEE Trans. Magn., Vol. MAG-11, No. 2, March 1975, pp. 615-618

(TRIS No. 127630 DA)

SUPERCONDUCTING LEVITATED HIGH SPEED GROUND TRANSPORTATION PROJECT IN JAPAN

Ohtsuka, T., and Kyotani, $Y$.

IEEE Trans. Magn., Vol. MAG-11, No.2, March 1975, pp. 608-614

(NTIS No. 75-09 0358 ')

REPUI_SION MAGNETIC SUSPENSION RESEARCH - U.S. PROGRESS TO DATE

Borcherts, R. H.

Cryogenics, Vol. 15, No. 7, July 1975, pp. 385-393

DEVELOPMENT OF SUPERCONDUCTING LEVITATED TRAINS IN JAPAN

Kyotani, $Y$.

Cryogenics, Vol. 15, No. 7, July 1975, pp. 372-376

(TRIS No. 128905 DA)

CANADIAN MAGLEV PROJECT ON HIGH-SPEED INTERURBAN TRANSPORTATION

Slemon, G. R.

IEEE Trans. Magn., Vol. MAG-11, No.5, Sept. 1975, pp.1478-148i

(NTIS No. 76-07 06848)

MAGNETIC LEVITATION TECHNOLOGY OF TRACKED VEHICLES PRESENT STATUS AND

PROSPECTS

Yamamura, S.

IEEE Trans. Magn., Vol. MAG-12, No.6, Nov. 1976, pp.874-878

(NTIS No. 77-08 08137)

DEVELOPMENT OF LEVITATED VEHICLES WITH SUPERCONDUCTING MAGNETS

Albrecht, $C$.

2nd Conf. on Adv, in Magn. Mater, and Their Appl., London, England, Sept.1-3 1976, IEE Proc. No.142, pp. 113-116 (Experimental results)

(NTIS No. 77-09 01376) (TRIS No. 167542DA) 
DESIGN AND TESTING OF A LOW SPEED MAGNETICALLY SUSPENDED VEHICLE

Linder, $D$.

2nd Coni. on Adv. In Magn. Mater. and Their Appl., London, England, Sept.1-3 1976, IEE Proc. No.142, pp. $96-99$

(NTiS No. 77-09 01372)

PASSENGER CARRYING VEHICLES USING CONTROLLED D.C. AND CONTROLLED PERMANENT MAGNETS

Jayawant, B. V.

2nd Corlt. on Adv. in Magn. Mater. and Their Appl., London, England, Sept.1-3, 1976, IEE Proc. No.142, pp. $92-96$

(NTIS No. 77-09 01371)

DEVELOPMENT OF 1-TON MAGNETICALLY SUSPENDED VEHICLE USING CONTROLLED D.C. ELECTROMAGNETS

Jayawant, B. V. et al.

Proc. Inst. Electr. Eng. (Lond.), Vol.123, No.9, Sept. 1976, pp. 941-948

(NTIS No. 77-10 02603)

ON RESEARCH AND DEVELOPMENT OF LEVITATION RAILWAY

Hobara, $T$.

Q. Rep. Railw. Tech. Res. Inst., (Jpn), Vol. 17, No. 4, Dec. 1976, pp. 144-181

(TRIS No. 168118 DA) (Review progress)

OUTLINE OF EXPERIMENTAL. TRACK FACILITIES IN MIYAZAKI FOR LEVITATION LINEAR MOTOR

CAR

Takeda, $\mathrm{H}$.

Japanese Railway Engineering, Vol. 17, No. 4, pp 7-9

(TRIS No. 178955 DA)

MAGNETICALLY SUSPENDED VEHICLES FOR URBAN TRANSPORT SYSTEMS

Jayawant, B. V.

Electron Power, Vol.23, No.3, March 1977, pp. 235-238

(NTIS No. 77-11 01246)

TENTH REPORT ON THE HIGH.SPEED GROUND TRANSPORTATION ACT OF 1965

U.S. Dept. Of Transp., FRAVORD-77/27, Washington, D. C., May 1977

MAGNETICALLY SUSPENDED VEHICLE

Linder, D., and Goodall, R. M.

Transp. Road Res. Lab.(GB) TRRL. Rep. No. 300, 1977, 16pp.

(NTIS No. 78-01 0472.3)

REPULSIVE-TYPE MAGNETIC LEVITATION SYSTEMS FOR HIGH SPEED TRANSPORT (SURVEY OF FOREIGN INVESTIGATIONS)

Vasil'ev, S. V.; Kim, K. I.; Matin, V. I.; Mikirtichev, A. A.

Izvestiia Vysshikh Ucheb Zaved, Elektromekhanika NB, Aug. 1977, pp. 882-888 (Russian)

(TRIS No. 177170 DA)

ELECTRODYNAMIC SUSPENSION AND LINEAR SYNCHRONOUS MOTOR PROPUI.SION FOR HIGH SPEED GUIDED TRANSPORTATIDN

Atherton, D. L.

Canadian Inst. of Guided Ground Transpont, Final Rep., Queen's Univ., Kingston, Ontario, Canada,

Sept. 1977, $264 \mathrm{pp}$.

(TRIS No. 176665 DA) 
THE CANADIAN HIGH-SPEED MAGNETICALLY LEVITATED VEHICLE SYSTEM Atherton, D. L., et al., ed. by Eastham, A. R.

Canadlan Inst. Gulded Ground Transport, Report 77-12, Queen's Univ., Kingston, Ontario, Canada, Sept. 1977

CANADIAN HIGH-SPEED MAGNETICALLY LEVITATED VEHICLE SYSTEM

Atherton, D. L.; Belanger, P. R.; Burke, P. E.; et al.

Can. Electr. Eng. J., Vol.3, No.2, April 1978, pp. 3-25

(NTIS No. 78-10 01180)

TECHNICAL ALTERNATIVES FOR A MAGLEV SYSTEM

Leonhard, W.

Electron Power, Vol.24, No. 4, April 1978, pp. 293-296

(NTIS No. 78.12 06803)

PROGRESS OF RESEARCH AND DEVELOPMENT ON REPULSIVE LEVITATION RAILWAY IN JNR Yamashita, $H$.

Q. Rep. Railw. Tech. Res. Inst. (Tokyo), Vol. 19, No.3, Sept. 1978, pp. 99-105

(NTIS No. 79-05 00828)

AN OVERVIEW OF THE U.S. POSITION ON NON-CONTACT SUSPENSION AND PROPULSION SYSTEMS

Palmer, J. D.

Int. Seminar on Supercc nctuciive Magnetic Levitated Train, Miyazaki, Japan, Nov, 1978, pp. 59-66

(Status report)

RESEARCI: AND DEVELOPMENT OF MAGLEV SYSTEMS IN THE U. K.

Rhodes, R. G.

Int. Seminar on Superconductiv Magnetic Levitated Train, Mlyazaki, Japan, Nov. 1978, pp. 50-58

(Status report)

TECHNOLOGIES FOR MAGNETIC LEVITATION SYSTEMS

Schulz, H.

Int. Seminar on Superconductive Magnetic Levitated Train, Miyazaki, Japan, Nov. 1978, pp. 37-49

(Status report)

STATUS OF HIGH SPEED MAGNETICALLY LEVITATED TRANSPORTATION RESEARCH IN CANADA Rudback, N. E.; Hayes, W. F.; Eastham, E. R.

Int. Seminar on Superconductive Magnetic Levitated Train, Miyazakl, Japan, Nov. 1978, pp.17-25

(Status report)

JNR'S MAGLEV: CLOSER TO COMMERCIAL PRACTICALITY?

Middleton, W. D.

Railway Age, Vol. 180, No. 15, Aug. 1979, pp. 32-33

(TRIS No. 300564 DA)

RUNNING TESTS ON SUPERCONDUCTING MAGNETIC LEVITATION SYSTEM (INTERCITY

PASSENGER RAILWAY)

Kyotani, $Y$.

Int. Conf. Transp. Electronics Proc., Utica, Michigan, 1980, Publ. IEEE-80CH1601-4, SAE-SP-90

(TRIS No. 380930) (Oveniew)

DEVELOPMENT OF THE MAGNETICALLY SUSPENDED TRANSPORTATION SYSTEM IN THE

FEDERAL REPUBL.IC OF GERMANY

Glatzel, K.; Khurdok, G.; Rogg, D.

IEEE Trans. Veh. Technol., Vol. Vt-29, No.1, Feb. 1980, pp. 3-17

(NTIS No. 80-09 01830) 
TRACKED AIR CUSHION VEHICLES AND MAGNETIC LEVITATION, 1964-MARCH, 1980 (CITATIONS FROM THE ENGINEERING INDEX DATA BASE)

Habercom, G. E.

National Technical Information Service, Springfield, Virginia, April1980, 147 pp., 141 Abstracts

(TRIS No. 318099 DA)

TEST RESULTS OF HSST MAGLEV SYSTEM

Nakamura, S.; Aizawa, H.; Eno, S.

Proc. Int. Cont. Cybern. Soc. Cambridge, Mass., Oct. 8-10, 1980, pp. 1036-1041

(NTIS No. 81.05 04164)

RESEARCH AND DEVEL.OPMENT PROGRAM MAGNETICALLY SUSPENDED TRANSPORT SYSTEMS IN THE FEDERAL REPUBLIC OF GERMANY

Glatzel, K.; Rogg, D.; Schulz, H.

Proc. Int. Cont. Cybern. Soc. Cambridge, Mass., Oct. 8-10, 1980, pp. $763-774$

(NTIS No. 81-05 04118)

MAGNETIC LEVITATION RAILWAY - RESULTS OF THE MIYAZAKI TESTS AND FUTURE PLANS Miyazakl, Kunio

Jpn Railw. Eng., Vol. 20, No. 4, 1981, pp. $2-5$

(NTIS No. 82-03 02167)

HIGH-SPEED MAGNETICALLY LEVITATED TRANSPORT DEVELOPMENT IN CANADA

Atherton, D. L.; Belanger, P. R.; Eastham, A. R.; et al.

J. Adv. Transp., Vol. 14, No. 1, Spring 1980, pp. 73-105

(NTIS No. 82-07 07345)

PRESENT STATUS OF RESEARCH AND DEVELOPMENT OF SUPERCONDUCTING MAGNETIC LEVITATION RAILWAY. RESEARCH ON LINEAR MOTOR MAGNETIC LEVITATION SYSTEM IN THIE JAPANESE NATIONAL RAILWAYS

Kyotani, $Y$.

Rail International, Vol. 12, No. 4, April 1981, pp. 155-163

(TRIS No. 341729 DA)

JR PRESSES ON WITH MAGLEV TRIALS

Railway Gazette Int., Vol. 137, No. 8, Aug. 1981, pp. 648-649

(TRIS No. 341705 DA)

TRANSRAPID MAGNETIC-LEVITATION TRANSPORT LONG-DISTANCE LINK FOR $400 \mathrm{~km} / \mathrm{h}$ Borchert, J.

Rail Eng. Int., Vol. 10, No.4, Oct.-Dec. 1981, pp. 119-121

(NTIS No. 82-09 03240)

MAGLEV TEST VEHICLE ML-500 RUNNING ON INVERTED-T-SHAPE GUIDEWAY

Nagaoka, H.; Nakashima, N.; Terada, K.; Fukase, S.

Hitachi Rev., Vol. 30, No.2, April 1981, pp. 93-96

(NTIS No. 82-10 02137) (Design)

MAGLEV TEST VEHICLE MLU 001 RUNNING ON A U-SHAPED GUIDEWAY

Fukase, S.; Nakashima, N.; Terada, K.; Takahashi, $H$.

Hitachi Rev., Vol. 31, No. 1, Feb. 1982, pp. 7-12

(NTIS No. 82-12 00108) 
MAGLEV RESEARCH IN THE U.K.

Rhodes, R. G.

The Second Int. Seminar on Superconductive Magnetic Levitated Train, Miyazaki, Japan, Noy. 1982, pp. $31-37$ (Status report)

AN UPDATE OF THE U.S. POSITION ON HIGH-SPEED, MAGNETICALLY LEVITATED VECHICLES Birmingham, B.W.

The Second Int. Seminar on Superconductive Magnetic Levitated Train, Miyazaki, Japan, Nov. 1982, pp. $25-30$

(Status report)

DEVELOPIMENT OF MAGNETICALLY LEVITATED HIGH SPEED TRANSPORT SYSTEMS IN THE FEDERAL REPUBLIC OF GERMANY

Rogg, D.

The Second Int. Seminar on Superconductive Magnetic Levitated Train, Miyazaki, Japan, Nov. 1982, pp. $16-24$

(Status report)

STATUS OF MAGNETICALLY LEVITATED TRANSPORTATION RESEARCH IN CANADA Eggleton, P.L.

The Second Int. Seminar on Superconductive Magnetic Levitated Train, Miyazaki, Japan, Nov. 1982, pp. $12-15$

(Status report)

CURRENT CANADIAN MAGLEV SYSTEM DESIGN CONCEPT AND ENERGY EFFICIENCY

Hayes, W. F.

The Second Int. Seminar on Superconductive Magnetic Levitated Train, Miyazaki, Japan, Nov. 1982, pp. $92 \cdot 101$ (Design concept)

MAGLEV - A BRITISH FIRST AT BIRMINGHAM

Pollard, M. G.

Phys. Technol., Vol. 15, No.2, March 1984, pp. 61-66, 72

(NTIS No. 84-06 09212)

PRESENT SITUATIONI CONCERNING JNR'S MAGNETIC LEVITATION SYSTEM

Fujii, $H$.

Civ. Eng. Jpn., Vol.22, 1983, pp. 127-136

(NTIS No. 84-07 02986)

VEHICLE OF THE EMSLAND TRANSRAPID TEST FACILITY (TVE)

Borchert, J., and Parnitzke, R. A.

J. Adv. Transp., Vol.17, No. 1, Spring 1983, pp. 57-71

(NTIS No. 84-09 01172)

DEVELOPMENT OF THE MAGNETICALLY LEVITATED TRAIN

Sasaki, $M$.

Jpn. Fiailw. Eng., Vol. 22, No. 4, 1983, pp. 20-24

(NTIS No. 83-12 03393) (TRIS No. 380232) (Review of development since 1977)

HSST-03 SYSTEM

Suzuki, S.; Kawashima, M.; Hosoda, Y.; Tanida, T.

IEEE Trans. Magn., Vol. MAG.-20, No.5, Sept. 1984, pp. 1675-1677

(NTIS No. 85-07 10169) 
PRESENT STATUS OF MAGLEV DEVELOPMENT IN JAPAN AND HSST-03 PROJECT

Masada, E.; Kitamoto, M.; Kato, J.; Kawashima, M.

Mechanical Engineering Publications Ltd., Box 24, Northgate Ave., Bury St., Edmunds, Suffolk, England, 1P32, 6PW, 1984, ? pp.

(TRIS No. 462935)

ELECTROMAGNETIC LEVITATION AND GUIDANCE TECHNOLOGY OF THE TRANSRAPID TEST FACILITY EMSLAND

Bohn, $G_{\text {, }}$ and Steinmetz, $G$.

IEEE Trans. Magn., Vol. MAG-20, No. 5, Sept.1984, pp. 1666-1671

(NTIS No. 85-07 10167)

THE ROMANIAN LINEAR INDUCTOR (SYNCHRONOUS) MOTOR (PASSIVE GUIDEWAY) MAGLEV

Boldea, l.; et al.

In Maglev Transport - Now and for the Future, IMechE 1984-12

TRANSRAPID MAGLEV SYSTEM - PROSPECTS FOR APPLICATION

Hessler, $\mathrm{H}$.

Rail Int., Vol.16, No.3, March 1985, pp. 69-71

(NTIS No. 85-09 11887)

PRESENT CONDITIONS OF SHINKANSEN AND DEVELOPMENT OF MAGLEV IN JNR.

Ono, J.

Rail Int., Vol. 16, No.1, Jan. 1985, pp. 111-115

(NTIS No. 85-11 12503)

LIM DRIVEN SUBWAY RAILCAR WITH SMALL SECTIONAL AREA

Shoyama, $Y$.; Ando, M.; Namikawa, $H$.

Proc., Int. Conf. Maglev Transport '85, Sept. 17-19, 1985, Keldanren Kaikan, Tokyo, Japan, Publ. by IEE, Japan, pp. 311-318

(System description and test results)

OPERATIONAL EXPERIENCE OF JNR'S MAGLEV TEST TRAIN

Tanaka, $\mathrm{H}$.

Proc., Int. Cont. Maglev Transport '85, Sept. 17-19, 1985, Keidanren Kaikan, Tokyo, Japan, Publ. by IEE, Japan, pp. 271-276

(Operational experience review)

GROUND FACILITIES AND OPERATIONAL EXPEAIENCE OF HSST-EXPO'85

Kawashima, M.; Hosoda, Y.; Takada, T.; Kitamoto, M.; Mihircigl, K.; Iwaya, M.

Proc., Int. Conf. Maglev Transport '85, Sept. 7-19, 1985, Ko Gijanren Kaikan, Tokyo, Japan, Publ. by IEE, Japan, pp. 263-270

(Operational experience review)

OPERATIONAL FXPERIENCE OF BIRMINGHAM MAGLEV

Mustow, S. N.

Proc., Int. Conf. Maglev Transport '85, Sept. 17-19, 1985, Keidanren Kaikan, Tokyo, Japan, Publ. by IEE, Japan, pp. 255-262

(Operational experience review)

OPERATION OF THE TRANSRAPID TEST FACILITIES IN EMSLAND

Politka, $P$.

Proc., Int. Conf. Maglev Transport '85, Sept. 17-19, 1985, Keidanren Kaikan, Tokyo, Japan, Publ. by IEE, Japan, pp. 251-254

(Operational experience review) 
BIRMINGHAM MAGLEV: DEVELOPMENT FOR THE FUTURE

Pollard, M. G., and Riches, E. E.

Proc., Int. Cont. Maglev Transport ' 85 , Sept. 17-19, 1985, Keidanren Kaikan, Tokyo, Japan, Publ. by IEE, Japan, pp.123-136

(Status report)

THE VEHICLE TRANSRAPID 06, SPECIFICATION AND EXPERIENCES UNDER PRACTICAL CONDITIONS

Gaede, P. J.

Proc., Int. Cont. Maglev Transport '85, Sept. 17-19, 1985, Keidanren Kaikan, Tokyo, Japan, Publ. by IEE, Japan, pp.115-121

(General description on system)

THE DEVELOPMENT OF MAGLEV TRANSPORT AND RELATED SYSTEMS IN JAPAN

Masada, E.

Proc., Int. Conf. Maglev Transport '85, Sept. 17-19, 1985, Keidanren Kaikan, Tokyo, Japan, Publ. by IEE, Japan, pp. 2.1-28

(Status report)

AN OVERVIEW OF CANADIAN MAGLEV RESEARCH AND DEVELOPMENT

Rudback, N. E.; Hayes, W.F.; Fife, A. A.; Eastham, A. R.; Audette, M. A.

Proc., Int. Cont. Maglev Transport ' 85 , Sept. 17-19, 1985, Keidanren Kaikan, Tokyo, Japan, Publ, by IEE, Japan, pp. 13-20

(Status report)

DEVELOPMENT OF MAGNETIC LEVITATION TRANSPORT SYSTEMS IN THE FEDERAL REPUBLIC OF GERMANY - SURVEY, PRESENT STATUS, PROSPECTS, AND REASONS

Dogg, D.

Proc., Int. Cont. Maglev Transport '85, Sept. 17-19, 1985, Keidanren Kaikan, Tokyo, Japan, Publ. by IEE, Japan, pp. 1-11

(Status report)

PRESENT CONDITIONS OF MAGLEV TEST ON JNH

Tanaka, $\mathrm{H}$.

Japan Railway Engineering No. 96, Dec. 1985, pp. 8-11

(TRIS No, 456310)

THE MAGLEV TRANSPORTATION SYSTEMS TRANSRAPID AND ULIMAS

Miller, $L$.

Proc., Int. Cont. Maglev and Linear Drives, May 14-16, 1986, Vancouver, B. C., Canada, Publ. by IEEE, 86CH2276-4, pp. 233-242

(Summary, discussion, and performance analysis)

CIVIL ASPECTS OF MAGLEV DESIGN

Zicha, J.H.

Proc., Int. Conf. Maglev and Linear Drives, May 14-16, 1986, Vancouver, B.C., Canada, Publ. by IEEE, 86CH2276-4, pp. 69-88

(Summary, discussion, and performance analysis)

EXPERIENCES WITH THE EMSLAND TRANSRAPID SYSTEM

Steinnetz, G.

Proc., Int. Cont. Maglev and Linear Drives, May 14-16, 1986, Vancouver, B. C., Canada, Publ. by IEEE, 86CH2276-4, pp. 59-66

(Status report and test results) 
THE TRANSRAPID MAGNETIC LEVITATION SYSTEM ON ITS WÄY TO BEING PUT INTO SERVICE Heinrich, $K$.

Proc., Int. Conf. Maglev and Linear Drives, May 14-16, 1986, Vancouver, B. C., Canada, Publ. by IEEE, 86CH2276-4, pp. 53-57

(Status report)

THE MAGNETIC TRAIN TRANSRAPID 06

Bohn, G., and Alscher, $H$.

Proc., Int. Conf. Maglev and Linear Drives, May 14-16, 1986, Vancouver, B.C., Canada, Publ. by IEEE, $86 \mathrm{CH} 2276-4$, pp. 47-52

(Subsystem introduction and status report)

PRESENT STATUS OF JNA MAGLEV DEVELOPMENT

Kyotani, $Y$., and Tanaka, $H$.

Proc., Int. Conf. Maglev and Linear Drives, May 14-16, 1986, Vancouver, B. C., Canada, Publ. by IEEE, 86CH2276-4, pp. 41-45

(Status report)

THE RESEARCH AND DEVELOPMENT PROGRAM "MAGNETICALLY SUSPENDED HIGH SPEED TRANSPORT SYSTEMS" IN THE FEDERAL REPUBLIC OF GERMANY

Rogg, D.

Proc., Int. Conf. Maglev and Linear Drives, May 14-16, 1986, Vancouver, B. C., Canada, Publ. by IEEE, $86 \mathrm{CH} 2276-4$, pp. 31-39

(Status report)

HSST-03 SYSTEM: OPERATIONAL SUMMARY AT EXPO '85 AND OPERATIONAL OUTLINE AT EXPO '36

Suzukl, S.; Mural, M.; Kawashima, M.; Hosoda, Y.

Proc., Int. Conf. Maglev and Linear Drives, May 14-16, 1986, Vancouver, B. C., Canada, Publ. by IEEE, $86 \mathrm{CH} 2276-4$, pp. 27-30

(Status report)

A REVIEW OF BIRMINGHAM MAGLEV AFTER ONE YEAR IN PUBLIC SERVICE

Dalgleish, E. H., and Riches, E. H.

Proc., Int. Conf. Maglev and Linear Drives, May 14-16, 1986, Vancouver, B. C., Canada, Publ. by IEEE, $86 \mathrm{CH} 2 ? 76-4$, pp. $1-5$

(Status report)

PRESENT STATE AND PROSPECTS OF MAGLEV TRANSPORT

Masada, E.

System and Control, Vol. 30, No. 9, Sept. 1986, pp. 543-552

(TRIS No. 468831)

THE MAGI EV TRANSRAPID SYSTEM ON THE WAY TO APPLICATION - TEST RESULTS

Merklinghaus, $W$., and Mnich, $P$

Proc., Int, Conf. Maglev and Linear Drives, Las Vegas, Nev., USA, May 19-21, 1987, Publ. by IEEE, 87CH2443-0, pp. 211-218

(Status report and test results)

MANUFACTURING PROCESS AND ASSEMBLING LINE OF GUIDEWAY AND ITS COMPONENTS OF THE TRANSRAPID MAGLEV SYSTEM

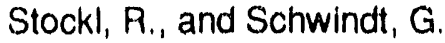

Proc., Int. Conf. Maglev and Linear Drives, Las Vegas, Nev., USA, May 19-21, 1987, Publ. by IEEE,

87CH2443-0, pp. 163-169

(Status report) 
TRANSRAPID $06 \|$ - PERFORMANCE AND CHARACTERISTICS

Miller, L.

Proc., Int. Conf. Maglev and Linear Drives, Las Vegas, Nev, IJSA, May 19-21, 1987, Publ, by IEEE, 87CH2443-0, pp. 155-162

(Status reprnt)

STATUS OF THE MAGLEV AND LINEAR DRIVE TECHNOLOGY PROGRAM IN THE FEDEFAL REPUBLIC OF GERMANY

Raschbichler, H. G., and Wackers, M.

Proc., Int. Crint. Maglev and Linear Drives, Las Verng, Nev., USA, May 19-21, 1987, Publ, by IEEE, $87 \mathrm{CH} 2443-0, \mathrm{pp} .147-154$

(Status report)

THE GOVERNMENT-SPONSORED PROGRAM "DEVELOPMENT OF THE MAGNETIC LEVITATION SYS TEM TRANSAAPID" IN THE FEDERAL REPUBLIC OF GERMANY

Menden, W., and Hartmann, P.

Proo., Int. Conf. Maglev and Linear Drives, Las Vegas, Nev., USA, May 19-21, 1987, Fubl. by IEEE, $87 \mathrm{CH} 2443-0$, pp. $143-146$

(Status report)

OPERATIONAL EXPERIENCE OF HSST-03 SYSTEM AT EXPO' 85 AND EXPO' 86

Suzukl, S.; Murai, M.; Kawashima, M.

Proc., Int. Conf. Maglev and Linear Drives, Las Vegas, Nev, USA, May 19-21, 1987, Publ, by IEEE, 87CH2443-0, pp. 129-141

(Stalus report)

THE M-BAHN DEMONSTRATION LINE IN RERLIN PROJECT; STATUS AND ARTISTIC IMPLEMENTATION

Eck, M. G.

f roc., Int. Cont. Maglev and Linear Drives, L.as Vegas, Nev., USA, May 19-21, 1987, Publ, by IEEE, 87CH2443-0, pp. 119-124

(Status report)

THE M-BAHN MAGLEV RAPID TRANSIT SYSTEM - TECHNOLOGY, STATUS, EXPERIENCE Drelmann, $K$.

Proc., Int. Cont. Maglev and Linear Drives, Las Vegaas, Nev., USA, May 19-21, 1987, Publ. by IEEE, 87CH2443-0, pp. 113-118

(Status report)

HSST-3 SYSTEM

Kawashima, M.; Takata, T.; Hosoda, Y.; et al.

Sumitomo Electr. Tech. Rev., No.25, Jan. 1986, pp. 144-151

(NTIS No. 86-05 06280)

TRANSRAPID MAGLEV UPDATE

Dickhart, W. W.

IEEE Aerosp. Electron. Syst., Mag., Vol.2, No.2, Feb. 1987, pp. 5-8

(NTIS No. 87-08 08506)

PRESENT STATUS OF MAGLEV DEVELOPMENT

Tanaka, $H$.

Society of Automotive Engineers Japan, Inc., Journal, Vol. 41, No. 2, Feb. 1987, pp. 166-170

(TRIS No. 468440)

DEVELOPMENT OF HIGH.SPEED GUIDE[) TRANSPORT - PAAT 2.

Barwell, F. T.

Electr. Veh. Dev., Vol.6, No.2, April 1987, pp.46-49

(NTIS No. 87-11 07495) 
CURVATURE RUNNING TEST RESULTS OF HSST VEHICLE

Hosoda, $Y_{\text {i; }}$ Kawashima, M.; Iwaya, M.; Hikasa, $Y_{\text {. }}$

IEEE Trans. Magn., Vol. MAG-23, No.5, Sept, 1987, pp. 2344-2346

(NTIS No. 88-07 07483)

DEVELOPMENT OF MAGNETICALLY LEVITATED TRANSPORTATION SYSTEM

Japan Rallway, Jan. 1988, Rallway System and Component, 35, Avallable from Japan Rolling Stock

Exporter's Assn., No. 1, Tekko Bldg., 8-2, Marunouchi 1-chome, Chiyoda-ku, Tokyo, Japan

MAGLEV SYSTEM DEVELOPMENT STATUS

Eastham, A. R., and Hayes, W. F.

IEEE Aerosp. Electron. Syst., Mag., Vol.3, No. 1, Jan. 1988, pp. 21-30

(NTIS No, 88-07 08124)

HIGH SPEED MAGLEV TRANSPORT SYSTEM TRANSRAPID

Meins, J.; Miller, L.; Mayer, W.J.

IEEE Trans. Magn., Vol.24, No.2, Mar, 1988, pp. 808-811

(NTIS No. 88-10 08944)

RECENT PROGRESS BY JNR ON MAGLEV

Kyotani, $Y$.

IEEE Trans. Magn., Vol.24, No.2, Mar. 1988, pp. 804-807

(NTIS No. 88-10 08943)

FIELD TESTS ON A MAGLEV WITH PASSIVE GUIDEWAY LINEAR INDUCTION MOTOR

TRANSPOPTATION SYSTEM

Boldea, 1.; Trica, A.; Papusolu, G.; Nasar, S. A.

IEEE Trans, Veh. Technol., Vol 37, No. 4, Nov. 1988, pp. 213-219

(NTIS No. 89-11 07994)

EXPERIMENTAL MAGNETIC LEVITATION RAILWAY LINE "TRANGRAPID" AT EMSLAND IN WESTERN GERMANY

Anon

Ind. Ital. Cem., Vol. 59, No. 3, Mar. 1989, pp. 170-181

(NTIS No. 89.11 02820)

THE STARLIM MAGLEV

Pascal, J.P.

Proc., 11 th int. Conf. Magnetically Levitated Syst, and Linear Drives, July 7-11, 1989, Yokohama, Japan, Publ. by IEE Jpn., pp. 111-114

M-BAHN MAGLEV TRANSIT SYSTEM EXPERIENCE, STATUS, APPLICATION

Dreimann, $K$.

Proc., 11th Int. Conf. Magnetically Levitated Syst. and Linear Drives, July 7-11, 1989, Yokohama, Japan, Publ. by IEE Jpn., pp. 101-104

HSST-05 SYSTEM GENERAL. AND OPERATIONAL OUTLINE AT YES'89

Ohishl, A.

Proc., 11th Int. Cont. Magnetically Levitated Syst, and Linear Drives, July 7-11, 1989, Yokohama, Japan, Publ. by IEE Jpn., pp. 93-100

PERFORMANCE ANALYSIS OF THE TRANSRAPID 07

Miller, L., and Ruoss, W.

Proc., 11 th Int. Conf. Magnetically Levitated Syst, and Linear Drive _, July 7-11, 1989, Yokohama, Japan, Publ. by IEE Jpn., pp. 85.92 
CURRENT STATUS OF EDS SYSTEM IN JAPAN

Fulle, J.

Proc., 11 th Int. Conf. Magnetically Levitated Syst. and Linear Drives, July 7-11, 1989, Yokohama, Japan, Publ. by IEE Jpn., pp. 81-83

PRESENT STATUS AND PROSPECT OF HSST

Nagaike, T., and Takatsuka, $H$.

Proc., 11 th Int. Cont. Magnetlcally Levitated Syst, and Linear Drives, July 7-11, 1989, Yokohama, Japan, Publ. by IEE Jpn., pp. 29-35

STATE OF DEVELOPMENT AND FUTURE PROSPECTS OF THE MAGLEV-SYSTEMS TRANSRAPID, $M$-BAHN AND STARLIM

Menden, W.

Proc., 11 th int. Conf. Magnetically Levitated Syst, and Linear Drives, July 7-11, 1989, Yokohama, Japan, Publ. by IEE Jpn., pp. 11-18

U.S. MAGLEV FINALLY LIFTS OFF

Carlson, L.

Superconductor - Industry, Vol. 4, No. 4, Winter 1991, pp. 12-16 


\section{Suspension and Levitation Techniques}

(Also see 10 Superconducting Magnets and Cryogenic Technologies)

MAGNETIC SUSPENSION AND GUIDANCE OF HIGH SPEED VEHICLES

Alston, I. A.; Clark, J. M.; Hayden, J. T.

Cranfield Center for Transport Studies, Bedford, England, Available from IPC Transport Press Limited, Dorset House, Stamford St., London, SE1 9LU, England

(TRIS No. 048297 DA)

MAGNETIC SUSPENSION AND GUIDANCE OF HIGH-SPEED VEHICLES

Coffey, H. T.; Chilton, F.; Barbee, T. W.

Proc. Low Temperatures and Electric Power Cunf., International Institute of Refrigeration, Paris, France, 1969, Bulletin I.I.F.II.I.R. 1969-1

FORCES ON MOVING MAGNETS DUE TO EDDY CLIRRENTS

Reitz, J. R.

J. Appl. Physics, Vol. 41, No. 5, 1970, pp. 2067-2071

MAGNETIC SUSPENSION FOR HIGH SPEED TRAINS

Rhodes, R. G., and Eastham, A. R.

Hovering Craft \& Hydrofoil, Vol. 11, No. 3, Dec. 1971, pp. 12-26

(TRIS No. 241679 DA)

FORCE ON A COIL MOVING OVER A CONDUCTING SURFACE INCLUDING EDGE AND CHANNEL

EFFECTS

Borcherts, R. H., and Davis, L. C.

J. Appl. Phys., Vol. 43, 1972, pp. 2418-2427

MAGNETIC SUSPENSION TECHNOLOGY FOR HIGH-SPEED TRAINS

Weh, $\mathrm{H}$.

Association Suisse Des Electriciens Bulletin, Vol. 64, No. 9. April 1973, pp. 564-571 (German)

(TRIS No. 047887 DA)

FORCE CALCULATIONS FOR HYBRID (FERRO-NULLFLUX) LOW-DRAG SYSTEMS

Danby, G. T.; Jackson, J. W.; Powell, J. R.

IEEE Intermag Conf., Toronto, Canada, May 7, 1972

ELECTROMAGNETIC LIFT AND DRAG FORCES ON A SUPERCONDUCTING MAGNET PROPELLED ALONG A GUIDEWAY COMPOSED OF METALLIC LOOPS

Hoppie, L. O.; Chilton, F.; Coffey, H. T.; Singleton, R. C.

Proc. Pap. 5th Int. Appl. Superconduct Conf., May 1-3, 1972, IEEE Publ. No. 72CH0682-5-TABSC,

pp. $113-119$

PRELIMINARY DESIGN STUDIES OF MAGNETIC SUSPENSIONS FOR HIGH-SPEED GROUND

TRANSPORTATION

Reitz, J. R., Borcherts, R. H.; Davis, L. C.; Hunt, T. K.; Wilkie, D. F.

U.S. Dept. of Transp., Rep. No. FRA-RT-73-27, March 1973

(NTIS No. 223237)

LEVITATION, DRAG AND TRANSVERSE FORCES IN FINITE WIDTH SHEET GUIDEWAYS FOR REPULSIVE MAGNETIC LEVITATION

Doi, 3. T.

High-Speed Ground Transp. Journal, Vol. 19, No. 1, pp. 369-373

(TRIS No. 096555 DA) 
PARAMETER OPTIMIZATION STUDIES MAGNETIC SUSPENSIONS FOR HIGH-SPEED GROUND TRANSPORTATION

Borcherts, R. H.; et al.

U. S. Dept. Transp., Rep. FRA-ORD\&D-74-12, April 1974

EDDY CURRENT DISTRIBUTION AND LIFT FORCE FOR FINITE MAGLEV STRIPS

Atherton, D. L.; Eastham, A. R.; Fombrum, C.; Chong, M.

Can. J. Phys., Vol. 52, No. 13, July 1974, pp. 1203-1208

(NTIS No. 74-10 04772)

LIMITATIONS OF LEVITATION BY IRON-CORED ELECTROMAGNETS

Atherton, D. L.; et al.

IEEE Trans. Magn., Vol. MAG-10, No. 3, 1974, pp. 410-412

PARAMETER OPTIMIZATION STUDIES OF MAGNETIC SUSPENSIONS FOR HIGH SPEED GROUND TRANSPORTATION

Borcherts, R. H.; Daris, L. C.; Wan, C. C.; Mohdulla, A. U.; Reitz, J. R.

U.S. Dept. Transp., Rep. FRA-ORD\&D-74-42, April 1974

(NTIS No. 75-05 04202)

COMPARISON AND OPTIMIZATION OF LIFT AND DRAG FORCES ON VEHICLES LEVITATED BY EDDY CURRENT FOR VARIOUS NULL AND NORMAL FLUX MAGNETS WITH ONE OR TWO TRACKS

Hogan, J. R., and Fink, H. J.

IEEE Trans. Magn., Vol MAG-11, No. 2, March 1975, pp. 604-607

(TRIS No. 127632 DA)

BASIC MAGNETIC LEVITATION SYSTEMS WITH A CONTINUOUS SHEET TRACK

Urankar, L.

Siemens Forsch Entwicklungsber Res. Dev. Rep., Vol. 4, No. 1, 1975, pp. 25-32

(NTIS No. 75-03 06575)

STUDY OF SUPERCONDUCTING MAGNETIC SUSPENSION AND GUIDANCE CHARACTERISTICS ON LOOP TRACKS

Iwahana, $\mathrm{T}$.

IEEE Trans. Magn., Vol. MAG-11, No. 67, Nov. 1975, pp. 1704-11

(TRIS No. 14111 DA), (Theoretical and experimental analysis)

NEW METHOD FOR STABLE LEVITATION OF AN IRON BODY USING SUPERCONDUCTORS Homer, G. J.; Randle, T. C.; Walters, C. R.; Wilson, M. N.; Bevir, M. K.

J. Phys. D. (Appl. Phys), Vol.10, No.6, April 21, 1977, pp. 879-886

(NTIS No. 77-08 0164)

INFLUENCE OF EDDY CURRENTS ON AN ELECTROMAGNETIC LEVITATION SYSTEM Bohn, G. H.

2nd Conf. on Adv. in Magn. Mater. and Appl., London, England, Sept. $1-3$ 1976, IEE Proc. No. 142, pp. 104-107

(NTIS No. 77-09 01374)

PASSIVE SUSPENSION DESIGN FOR A MAGNETICALLY LEVITATED VEHICLE

Belanger, P. R., and Guillemette, R.

Proc. of the Autom. Control Conf., San Francisco, Calif., June 22-24, 1977, pp. 1476-1486

(NTIS No. 78.01 02788)

ANALYSIS OF MAGNETIC SUPPORT SYSTEMS OF ELECTRIC TRACTION ARRANGEMENTS FOR HIGH SPEED SURFACE TRANSPORT AND SELECTION OF LINES OF FURTHER FIESEARCH

Shapovalenko, A. G.; Gavilyuk, V. A.; Zukin, P.P.

Izvestiia Vysshikh Ucheb Zaved, Elektromekhanika NB, Aug. 1977, pp. 879-881 (Russian)

(TRIS No. 177171 DA) 
SOME PROBLEMS OF THE THEORY OF ELECTRODYNAMIC SUSPENSION OF HIGH-SPEED SURFACE TRANSPORT (HSST) VEHICLES

Treshchev, I. I.; Kochetkov, V. M.; Yudakov, Y. V.

Izves!lia Vysshikh Ucheb Zaved, Elektromekhanika NB, Aug. 1977, pp. 871-874 (Russian)

(TRIS No. $177173 \mathrm{DA})$ (Theoretical analysis)

HOW TO CALCULATE LEVITATION CHARACTERISTICS IN ELECTRODYNAMIC SUSPENSION OF HIGH-SPEED VEHICLES

Kochetkov, V. M.

Power Eng. (New York), Vol.15, No.5, 1977, pp. 98-105

(NTIS No. 79-05 06804)

LEVITATION CHARACTERISTICS OF MAGNETICALL.Y SUSPENDED VEHICLES UTILIZING CONTINUOUS CONDUCTIVE SHEETS

Takahashi, T.

Electrical Engineering in Japan, Vol. 96, No. 6, Nov. 1977, pp. 97-105

(TRIS No. 17.4035 DA)

MAGNETIC SUSPENSION FOR LOW-SPEED VEHICLES

Sinha, P. K.

J. Dyn. Syst., Meas. Control, Trans. ASME, Vol.100, No, 4, Dec. 1978, pp. 333-342

(NTIS No. 79-06 00883)

DESIGN OF SUSPENSION SYSTEMS WITH MAGNETIC LEVITATION

Tozoni, O. V., and Nikolaeva, N. S.

Power Eng. (New York), Vol.16, No.5, 1978, pp. 28-35

(NTIS No. 79-11 02033)

FORCES AND MOMENTS FOR ELECTRODYNAMIC LEVITATION SYSTEMS - LARGE-SCALE TEST RESULTS AND THEORY

Atherton, D. L.; Eastham, A. R.; Ooi, B. T.; Jain, O. P.

IEEE Trans. Magn., Vol. MAG-14, 1978, pp. 59-68

PASSENGER CARIRYING VEHICLES USING CONTROLLED ELECTROMAGNETS FOR SUSPENSION Jayawant, B. $V$.

Proc. Int. Cont. Electr. Mach., Vol.1, Brussels, Belgium, Sert. 11-13, 1978, Organ. by Kathol Univ., Louvain, pp. L7. 2.1 - L7. 2.6

(NTIS No. 80-12 07871)

MOMENTS AND FORCE DENSITIES OF THE ELECTRODYNAMIC LEVITATION SYSTEM

Ooi, B. T., and Jain, O.P.

IEEE Trans. Magn., Vol. MAG-15, No. 3, May 1979, p. 1102

(TRIS No. 307648 DA)

SUBOPTIMAL SEMI-ACTIVE VEHICLE SUSPENSIONS

Hrovat, D.; Hubbard, M.; Margolis, D. L.

Proc. Jt. Autom. Control Conf., An ASME Century 2 Emerging Technol. Conf., Vol.1, San Francisco, Calif., Aug.13-15, 1980 (Cat. No. 81CH1580.0)

(NTIS No. 81-05 08241)

CHARACTERISTICS OF A MAGLEV VEHICLE RUNNING ON ALUMINIUM SHEET GUIDEWAYS Iwahana, T.; Iketan, T.; Fujimoto, T.

Q. Rep. Railw. Tech. Res. Inst. (Jpn), Vol.21, No.4, Dec. 1980, pp. 174-179

(NTIS No. 81-09 04801) 
DAMPING CHARACTERISTICS AND AC MAGNETIC FIELD OF REPUL.SIVE MAGNETIC LEVITATION

Fuliwara, S., and Hariyama, T.

Q. Rep. Railw. Tech. Res. Inst., (Jpn), Vol. 24, No. 2, June 198 3, p. 93

(TRIS No. 382253), (Experimental analysis)

MAGNET/RAIL SYSTEMS - A CRITICAL REVIEW OF THE OPTIONS

Armstong, D. S.

Int. Conf. Maglev Transp.: Now and for the Future, Solihull, England, Oct. 9-12, 1984, line Conf.

Publications 1984-12, Available from Mechanical Engineering Publications Ltd. Box 24, Northgate Ave.,

Bury St., Edmunds, Suffolk 1P32, 6PW, England, 1984, pp. 59

(TRIS No. 462931)

A NEW FORM OF MAGNETIC SUSPENSION FOR HIGH SPEED MAGLEV TRANSPORT

Paul, R.J. A.; Asher, G. M.; Williams, J. T.; Brown, J.

Int. Conf. Maglev Transp.: Now and for the Future, Solihull, England, Oct. 9-12, 1984, IME Cont.

Publications 1984-12, Avallable from Mechanical Engineering Publications Ltd., Box 24, Northgate Ave., Bury St., Edmunds, Suffolk 1P32, 6PW, England, 1984, pp. 67

(TRIS No. 462933)

PERFORMANCE OF INDUCTION LEVITATORS

Eastham, J. F. and Rodger, D.

IEEE Trans. Magn., Vol. MAG-20, No.5, Sept. 1984, pp.1684-1686

(NTIS No. 85-07 10172)

TRANSVERSE FLUX ELECTRODYNAMIC LEVITATION SYSTEM

Gieras, J. F.

Proc., Int. Conf. Maglev Transport '85, Sept. 17-19, 1985, Keidanren Kaikan, Tokyo, Japan, Publ. by IEE, Japan, pp. 207-215

(Theoretical and experimental analysis)

EXPERIMENTAL STUDIES OF THE SUPERCONDUCTING SPLIT TRACK MAGLEV SYSTEM

Mahtani, J. L., and Rhodes, R. G.

Proc., Int. Cont. Maglev Transport '85, Sept. 17-19, 1985, Keidanren Kaikan, Tokyo, Japan, Publ. by IEE, Japani, pp. 199-205

(Experimental analysis)

A PROPOSAL. OF NEW STRUCTURE FOR ELECTROMAGNETIC LEVITATION SYSTEM FOR TRAINS Yamamura, S., and Yamaguchi, $H$.

Proc., Int. Conf. Maglev Transport '85, Sept. 17-19, 1985, Keidanren Kaikan, Tokyo, Japan, Publ. by IEE, Japan, pp. 165-172

(Theoretical analysis and design with some experimental results)

FAST ACTING MAGNETS FOR TRANSPORTATION PURPOSES

Weh, $H_{\text {., }}$ and May, $H$.

Proc., Int. Conf. Maglev Transport '85, Sept. 17-19, 1985, Keidanren Kalkan, Tokyo, Japan, Publ. by IEE, Japan, pp. 155-163

(Design and analysis of various types of magnets)

EVALUATION-MODULE/SUSPENSION SYSTEM INSTALLED ON THE HSST-03 VEHICLE

Kitamoto, M.; Suzuki, S.; Iwaya, M.; Kato, J.; Kawashima, M.; Shimada, T.

Proc., Int. Conf. Maglev Transport ' 85 , Sept. $17-19,1985$, Keidanren Kaikan, Tokyo, Japan, Publ. by IEE, Japan, pp. 137-144

(Test results) 
THE ELECTROMAGNETIC SUSPENSION SYSTEM OF THE MAGNETIC TRAIN "TRANSRAPID" Bohn, G., and Steinmetz, G.

Proc., Int. Conf. Maglev Transport '85, Sept. 17-19, 1985, Keidanren Kaikan, Tokyo, Japan, Publ. by IEE, Japan, pp. 107-114

(System description and experimental results)

ELECTROMAGNETIC LEVITATION SYSTEM BY MEANS OF SALIENT-POLE TYPE MAGNETS COUPLED WITH LAMINATED SLOTLESS RAILS

Yamamura, S., and Yamaguchi, $\mathrm{H}$.

Proc., Int. Conf. Maglev and Linear Drives, May 14-16, 1986, Vancouver, B. C., Canada, Publ, by IEEE, 86CH2276-4, pp. 227-232

(Theoretical design and analysis)

STUDY FOR OPTIMIZATION OF GROUND COILS OF REPULSIVE TYPE MAGLEV

Fujiwara, S., and Terauchi, N.

Proc., Int. Cont. Maglev and Linear Drives, May 14-16, 1986, Vancouver, B. C., Canada, Publ. by IEEE, 86CH2276-4, pp. 95-99

(Theoretical analysis)

THE REDUCTION OF LATERAL FORCE BY THE ARRANGEMENT OF PERMANENT MAGNETS IN THE PM-TYPE MAGNETIC LEVITATION DEVICE

Eblhara, D.; Suzukl, T.; Imagawa, K.

Proc., Int. Cont. Maglev and Linear Drives, Las Vegas, Nev., USA, May 19-21, 1987, Publ. by IEEE, 87CH2443-0, pp. 95-98

LATERAL BEHAVIOUR OF A MAGNETIC WHEEL AND ITS COORDINATION WITH THE MAGLEV CONTROL SYSTEM

Masada, E.; Koseki, T.; Kawashima, M

Proc., Int. Cont. Maglev and Linear Drives, Las Vegas, Nev., USA, May 19-21, 1987, Publ. by IEEE, $87 \mathrm{CH} 2443-0$, pp. 87-93

ELECTROMAGNETIC SUSPENSION AND LEVITATION TECHNIQUES Jayawant, B. V.

Proc. A. Soc. London Ser. A, Vol.416, No.1851, April 8, 1988, pp, 245-320

(NTIS No. 88.08 06829)

CHARACTERISTICS OF EDS MAGNETIC LEVITATION WITH GROUND COILS FOR LEVITATION ARRANGED ON THE SIDE WALL.

Fujiwara, $S$.

Electr. Eng. Jpn., Vol. 108, No.3, May-June 1988, pp. 101-110

(NTIS No. 89-03 02281)

CHARACTERISTICS OF EDS MAGLEV HAVING LEVITATION COILS ON THE SIDE WALL OF THE GUIDEWAY

Fujiwara, $S$.

Q. Rep. Railw. Tech. Fes. Inst. (Jpn), Vol. 29, No. 4, Nov. 1988, pp. 157-163

(NTIS No. 89-04 02124)

ATTRACTIVE LEVITATION FOR HIGH-SPEED GROUND TRANSPORT WITH LARGE GUIDEWAY CLEARANCE AND ALTERNATING-GRADIENT STABILIZATION

Hull, J.R.

IEEE Trans. Magn., Vol. MAG-25, No. 5, Sept. 1989, pp. 3272-3274

DESIGN OF THE HYBRID MAGNET IN THE MAGNETIC LEVITATION SYSTEM BY THE BOUNDARY ELEMENT METHOD

Amano, $H_{\text {; }}$ Murai, T.; Onuki, T.

Proc., 11th Int. Cont. Magnetically Levitated Syst. and Linear Drives, July 7-11, 1989, Yokohama, Japan, Publ. by IEE Jpn., pp. 441-446 
STUDY ON FUNDAMENTALS OF MECHANICALLYY CONTROLLED PERMANENT MAGNET LEVITATION SYSTEM FOR MAGLEV TRANSPORT VEHICLE

Abe, $M_{\text {.; }}$ Fukumoto, $Y_{\text {,; }}$ Tsunashima, $H$.

Proc., 11th Int. Conf. Magnetically Levitated Syst, and Linear Drives, July 7-11, 1989, Yokohama, Japan, Publ, by IEE Jpn., pp. 387-392

A NEW ELECTROMAGNETIC GUIDANCE TECHNOLOGY WITH NO GUIDANCE MAGNETS Morishita, M., and Azukizawa, T.

Proc., 11 th Int. Conf. Magnetically Levitated Syst. and Linear Drives, July 7-11, 1989, Yokohama, Japan, Publ, by IEE Jpn., pp. 381-386

MAGNET CONCEPTS WITH ONE-AND TWO-DIMENSIONAL STABLE SUSPENSION

CHARACTERISTICS

Weh, H.; May, H.; Hupe, $H$.

Proc., 11th Int. Cont. Magnetically Levitated Syst. and Linear Drives, July 7-11, 1989, Yokohama, Japan, Publ. by IEE Jpn., pp. 251-256

STUDY FOR HARMONIC RIPPLE OF ELECTROMAGNETIC FORCE IN SUPERCONDUCTING MAGNETICALLY LEVITATEO VEHICLE WITH NON-RECTANGULAR GROUND COILS

Saitoh, T.; Miyashita, K.; Klwaki, $H$.

Proc., 11th Int. Cont. Magnetically Levitated Syst. and Linear Drives, July 7-11, 1989, Yokohama, Japan, Publ. by IEE Jpn., pp. 245-2.49

CHARACTERISTICS OF THE COMBINED LEVITATION AND GUIDANCE SYSTEM USING GROUND COILS ON THE SIDE WALL OF THE GUIDEWAY

Fujiwara, S.; Fujimoto, $T$.

Proc., 11 th int. Conf. Magnetically Levitated Syst. and Linear Drives, July 7-11, 1989, Yokohama, Japan, Publ. by IEE Jpn., pp. 241-244

VELOCITY DEPENDENCE OF LEVITATION POSITION OF A MAGNETICALLY LEVITATED VEHICLE Kobayashi, T.; Shibata, M.; Makl, N.; Saito, T.

Proc. 1991 National Convention of the Institute of Electrical Engineers (IEE of Japan).

CHARACTERISTICS OF THE NULL. FLUX TYPE LEVITATION SYSTEM WITH RACE TRACK SHAPED SUPERCONDUCTING COIL.

Fuhiwara, S. and Fulimoto, T.

Proc. 1990 National Convention of the Institute of Electrical Engineers (IEE of Japan).

SUPERCONDUCTING MAGNETIC I.EVITATION AND LINEAR SYNCHRONOUS MOTOR PROPUL.SION FOR HIGH SPEED GUIDED GROUND TRANSPORTATION

Eastham, A.R., Editor

Canadian Inst. of Guided Ground Transport, CIGGT Report No. 75-5, Queen's Univ., Kingston, Ontario, Canada, March 1975, 297 pp.

(TRIS No. 141128DA)

SUPERCONDUCTING MAGNETIC IEVITATION AND LINEAR SYNCHRONOUS MOTOR PROPULSION FOR HIGH-SPEED GUIDED GROUND TRANSPORTATION

Eastham, A.R., Editor

Canadian Inst. of Guided Ground Transport, CIGGT Report No. 77-13, Queen's Univ., Kingston, Ontario, Canada, Sept. 1977, $180 \mathrm{pp}$. 


\section{LInear Propulsion Techniques}

PROPOSED PAOPULSION SYSTEM FOR MAGNETICALLY LEVITATED GUIDED GROUND TRANSPORTATION

Atherton, D. L.

Proc. Pap. 5th Int. Appl. Superconduct Conf., Annapolis, Md., May 1-3, 1972 pp. 110-112

(NTIS No. 74-02 02965)

MAGNETIC PROPULSION FOR MAGNETICALLY LEVITATED TRAINS

Melville, P. H.

Cryogenics, Vol. 13, No. 12, Dec. 1973, pp. 716-717

(TRIS No. 056804 DA)

LINEAR SYNCHRONOUS MOTORS FOR HIGH-SPEED GROUND TRANSPORTATION

LeVI, E.

IEEE Trans. Magn., Vol. MAG-9, No. 3, Sept. 1973, pp. 242-248

ANALYYSIS OF SUPEFICONDUCTING MAGNETIC LEVITATION AND LINEAR SYNCHRONOUS MOTOR PROPULSION FOR HIGH SPEED GUIDED GROUND TRANSPORTATION

Canadian Inst. of Gulded Ground Transport, Queen's Univ., Kingston, Canada, Project No. D.71.72,

$235 \mathrm{pp}$.

(TRIS No. 126463)

CONFERENCE ON LINEAR ELECTROMAGNETIC MACHINES, HELD AT IEE,

LONDON, OCT. 21-23, 1974

1974 Conf. Paper, 250 pp., IEE, Savoy Place, London, WC2R OBL, England

(TRIS No. 125581 DA)

CHARACTERISTICS OF PROPULSION SYSTEM OF THE MAGNETIC LEVITATION VEHICLE NAMED ML-100

Fujwara, S.

Q. Rep. Railw. Tech. Res. Inst., Vol. 16, No. 2, June 1975, pp. 77-78

(TRIS No. 127350 DA)

CANADIAN DEVELOPMENTS IN SUPERCONDUCTING MAGLEV AND LINEAR SYNCHRONOUS MOTORS

Atherton, D. L., and Eastham, A. R.

Cryogenics, Vol. 15, No. 7, July 1975, pp. 395-402

ASSESSMENT OF LINEAR SUPERCONDUCTING MOTORS FOR MAGLEV

Abel, E.; Mahtani, J. L.; Mulhall, B. E.; Rhodes, R. G.

2nd Conf. on Adv. in Magn. Mater. and Appl., London, England, Sept. 1-3, 1976, IEE Proc. No. 142, pp. $125-127$

(NTIS No. 77-09 01379)

NORMAL FORCE VARIATION IN SINGLE-SIDED LINEAR INDUCTION MACHINES

Freeman, E. M., and Lowther, D. A.

2nd Conf. on Adv. in Magn. Mater. and Appl, London, England, Sept. 1-3 1976, IEE Proc. No. 142, pp. $128-130$

(NTIS No. 77-09 01380)

DESIGN, ANALYSIS AND TEST RESULTS FOR A SUPERCONDUCTING LINEAR SYNCHRONOUS MOTOR

Atherton, D. L.; Cunningham, J. A.; Dewan, S. B.; Eastham, A. R.; Slemon, G. R.; Turton, R. A.

IEE Proc., Vol. 124, No. 4, April 1977, pp. 363-372

(TRIS No. 167563 DA) (Test results frorn 7.6 m-diameter wheel) 
THE AIR-CORED LINEAR SYNCHRONOUS MOTOR: THE STATE OF THE ART IN ERLANGEN Parsch, C. P., and Wlegner, G. Int. Seminar on Superconductive Magnetic Levitated Train, Mlyazakl, Japan, Nov, 1978, pp. 98-107 (Overviow, test results)

NORMAL FORCES IN LINEAR INDUCTION MOTORS WITH WOUND SECONDARY Andresen, E., and Baentz, U.

Proc. Int. Conf. Electr. Mach., Vol. 1, Brussels, Belgium, Sept. 11-13, 1978, Organ. by Kathol Univ., Louvain, pp. L.1. 1. 1 - L.1.1.14

(NTIS No. 80-12 07706)

LINEAR SYNCHRONOUS MOTOR FOR URBAN TRANSIT USING RARE-EARTH MAGNET

Slemon, G. R.; Burke, P. E.; Terzis, N.

IEEE Trans. Magn., Vol. MAG-14, No.5, Sept. 1978, pp. 921-923

(NTIS No. 79-07 02809)

PROPULSION CONTROL OF A TRACK-POWERED LINEAR SYNCHRONOUS MOTOR FOR A MAGNETICALLY LEVITATED VEHICLE ON THE BASIS OF POWER MEASUREMENT IN THE INVERTOR STATION

Boening, B., and Leonhard, W.

Proc. Int. Conf. Electr. Mach., Vol. 1, Brussels, Belgium, Sept. 11-13, 1978, Organ. by Kathol Univ., Louvain, pp. L5, 1. 1 - L5. 1.9

(NTIS No. 80-12 07730)

DESIGN AND TECHNOLOGY OF THE IRON-CORE LINEAR SYNCHRONOUS MOTOR FOR ADVANCED GROUND TRANSPOATATION

Weh, H.; Mosebach, H.; May, H.

Proc. Int. Conf. Electr. Mach., Vol. 1, Brussels, Belgium, Sept. 11-13, 1978, Organ. by Kathol Univ., Louvain, pp. L.4. 5. 1 -L.4. 5. 10

(NTIS No. 80-12 07729)

HOMOPOLAR LINEAR SYNCHRONOUS MOTOR

Slemon, G. R.

Proc. Int. Conf. Electr. Mach., Vol. 1, Brussels, Belgium, Sept. 11-13, 1978, Organ. by Kathol Univ., Louvain, pp. L.4. 4. 1 -L4. 4. 10

(NTIS No. 80-12 07728)

AIR-CORED LINEAR SYNCHRONOUS MOTOR: THE STATE OF THE ART IN ERLANGEN Parsch, C. P.. and Wiegner, G.

Proc. Int. Cont. Electr. Mach., Vol. 1, Brussels, Belgium, Sept. 11-13, 1978, Organ. by Kathol Univ., Louvain, pp. L4. 3. 1 -L4. 3. 13

(NTIS No. 80-12 07727)

CHARACTERISTICS OF THE FORCE COMPONENTS OF AN AIR-CORED LINEAR SYNCHRONOUS MOTOR WITH SUPEP.CONDUCTING EXCITATION MAGNETS

Lingaya, $S_{\text {., }}$ and Persch, C.P.

Proc. Int. Conf. Electr. Mach., Vol. 1, Brusseis, Belgium, Sept. 11-13, 1978, Organ. by Kathol Univ., Louvain, pp. L4. 2. 1 -L4. 2. 11

(NTIS No. 80-12 07726)

LINEAR RELUCTANCE MACHINES FOR URBAN TRANSPORT

Chahal, J.S.

Proc. Int. Cont. Electr. Mach., Vol. 1, Brussels, Belgium, Sept. 11-13, 1978, Organ. by Kathol Univ., Louvain, pp. L.4. 1. 1 - L.4. 1. 10

(NTIS No. 80-12 07725) 
COMPARISON BETWEEN ASYNCHRONOUS AND SYNCHRONOUS LINEAR MOTORS OF SHORT STATOA CONSTRUCTION

Rentmelster, $M$.

Proc. Int. Conf. Electr. Mach., Vol. 1, Brussels, Belgium, Sept. 11-13, 1978, Organ. by Kathol Univ., Louvain, pp. L3. 5. 1 -L3. 5. 11

(NTIS No. 80-12 07722)

PROPULSION SYSTEMS FOR MAGNETICALLY SUSPENDED VEHICLES

Lang, A.

Proc. Int. Conf. Electr. Mach., Vol. 1, Brussels, Belgium, Sept. 11-13, 1978, Organ. by Kathol Univ., Louvain, pp. L3. 3.1 - L3. 3.10

(NTIS No. 80-12 07720)

COMPARISON OF SINGLE SIDED AND DOUBLE SIDED LINEAR MOTORS

Oberretl, $K$.

Proc. Int. Cont. Electr. Mach., Vol. 1, Brussels, Belglum, Sept. 11-13, 1978, Organ. by Kathol Univ., Louvain, pp. L1. 4. 1-L1. 4. 8

(NTIS No. 80-12 07709)

ASSESSMENT BY SCALING TESTS OF ELECTROMAGNETIC LINEAR MACHINES

Glovachini, J.L.; Leyrit, M.; Pascal, J. P.

Proc. Int. Conf. Electr. Mach., Vol. 1, Brussels, Belglum, Sept. 11-13, 1978, Organ. by Kathol Univ., Louvain, pp. L1. 3. 1 - L1. 3.10

(NTIS No. 80-12 07708)

PERMANENT MAGNETIC EXCITATION OF ROTATING AND LINEAR SYNCHRONOUS MACHINES

Weh, $H_{\text {., }}$ and May, $H$.

J. Magn. Mater., Vol.9, No.1-3, Oct.-Nov. 1978, pp. 173-178

(NTIS No. 79-05 06608)

LINEAR SYNCHRONOUS PROPULSION WITH PERMANENT MAGNET EXCITATION

Weh, $\mathrm{H}$.

Proc. Int. Conf. Cybern. Soc., Cambridge, Mass., Oct. 8-10, 1980 (Cat. No. 80CH1555-2),

pp. $1042 \cdot 1049$

(NTIS No. 81-05 04165)

SINGLE-SIDED LINEAR INDUCTION MOTORS WITH CAGE AIND SOLID-STEEL REACTION RAILS FOR INTEGRATED MAGNETIC SUSPENSION AND PROPULSION OF GUIDED GROUND TRANSPORT

Katz, R. M., and Eastham, T. R.

Cont. Rec. 15th IAS Ann. Meet., Cincinnati, Ohio, Sept. 28-Oct. 3, 1980, pp. 261-269

(NTIS No. 81-11 06708)

DESIGN PRINCIPLE OF THE HIGH SPEED SINGLE-SIDED LINEAR INDUCTION MOTORS FOR

PROPULSION OF MAGNETICALLY LEVITATED TRAINS

Nonaka, S., and Higuchi, T.

Electr. Eng. Jpn., Vol.101, No.4, July-Aug. 1981, pp. 96-105

(NTIS No. 83-04 01540)

OPTIMUM LINEAR SYNCHRONOUS MOTOR DESIGN FOR HIGH SPEED GROUND TRANSPORTATION Azukizawa, $T$.

IEEE Trans. Power Appar. Syst., Vol. PAS-102, No. 10, Oct. 1983, pp. 3306-3314

(NTIS No. 84-01 08673)

PROJECT DESIGN OF A MAGLEV SYSTEM WITH SHORT-STATOR LINEAR MOTOR PROPUL.SION Gaede, P. J.

J. Adv. Transp., Vol. 17, No.1, Spring 1983, pp. 49.56

(NTIS No. 84-09 01171) 
TECHNICAL CONCEPT AND SYSTEM DATA OF A MAGNETICALLY SUSPENDED TRAIN WITH PROPULSION BY SHORT STATOR LINEAR INDUCTION MOTOR

Gaede, P. J.

Slemens (Georg) Verlagsbuchhandlung, Glasers Annalen ZEV, Vol. 107, No. 12, Deo. 1983, pp. 411.416 (German)

(TRIS No. 382635)

L.ATERAL FORCES IN LINEAR RELUCTANCE MOTORS

El-Antably, A.M.

Eletr. Mach. Power Syst., Vol.9, No.6, 1984, pp.413-420

(NTIS No. 85.05 02329)

LINEAR SYNCHRONOUS MACHINES FOR MAGNETICALLY-LEVITATED VEHICLES

AnON

IEE Colloq. Dig. No. 1983/11, Linoar Synchronous Mach. for Magn.-Levitated Veh., London, England,

Feb. 4, 1983, Item No. 709266

(NTIS No. 85-09 11391)

PROPULSION AND POWER SUPPLY SYSTEM OF THE TRANSRAPID O6 VEHICLE DESIGN AND

TEST RESULTS-PART 1: PROPULSION

Friedrich, R.; Drelmann, K.; Lelstikow, R.; Bohm, E.; Weller, A.

Proc., Int. Cont. Maglev Transport '85, Sept. 17-19, 1985, Keidanren Kaikan, Tokyo, Japan, Publ. by IEE, Japan, pp. 75-82

(General discussion on design and test results)

INFLUENCE OF CONDUCTIVE CAP THICKNESS ON THE PERFORMANCE OF SINGLE-SIDED LINEAR INDUCTION MOTORS

Gleras, J. F.; Eastham, A. R.; Dawson, G. E.

Electr. Mach. Power $\}$,'st., Vol.11, No.2, 1986, pp.125-136

(NTIS No. 86-05 02952)

SHORT-STATOR PROPULSION SYSTEM OF HSST-03

Masada, E.; Fujisaki, K.; Kitamoto, M.; Takeuchi, H.; Kawashima, M.; Hosoda, Y.

Proc., Int. Cont. Maglev Transport '85, Sept. 17-19, 1985, Keidanren Kalkan, Tokyo, Japan, Publ. by IEE, Japan, pp. 61.68

(Test results)

ANALYSIS OF LINEAR INDUCTION DRIVES BY ELECTFIOMAGNETIC AND FINITE EI.EMENT

TECHNIQUES

Eastham, A. R.; Dawson, G. E.; Gieras, J. F.; Ong, R.; Ananthasivam, K.

Proc., Int. Conf. Maglev Transport '85, Sept. 17-19, 1985, Keidanren Kaikan, Tokyo, Japan, Publ. by IEE, Japan, pp. 53-60

(Theoretical, numerical and experimental results)

ON THE DESIGN OF SINGLE-SIDED LINEAR INDUCTION MOTORS FOR PROPULSION OF MAGLEV

VEHICLES

Higuchi, T, and Nonaka, S.

Proc., Int. Conf. Maglev Transport '85, Sept. 17-19, 1985, Keldanren Kaikan, Tokyo, Japan, Publ. by IEE, Japan, pp. 45-52

(Design with examples)

ON SUITABLE ANALYTICAL METHOD FOR LIM PHOPULSION

Nonaka, S., and Furukawa, T.

Proc., Int. Cont. Maglev Transport '85, Sept. 17-19, 1985, Keidanren Kaikan, Tokyo, Japan, Publ. by IEE, Japan, pp. 37-44

(Analytical and numerical results) 
AN ANALYSIS OF A THIN STEEL ROTOR, DOUBLE SIDED, ANNULAR, LINEAR INDUCTION MOTOR Peabody, F.; Duntord, W. G.; Brdioko, J.

Proo., Int. Cont. Magiev and Linear Drives, May 14-16, 1986, Vanoouver, B. C., Canada, Publ, by IEEE, $86 \mathrm{CH} 2276-4$, pp. 193-198

(Theoretical and experimental analys/s)

APPROACH TO PERFORMANCE CALCULATION OF A SINGLE-SIDED LINEAR INDUCTION MOTOR WITH A CAGE REACTION RAIL.

Gleras, J. F.; Eastham, A. R.i Dawson, G. E.; Ballantyne, W.J.

Proc., Int. Cont. Maglev and Linear Drives, May 14-16, 1986, Vancouver, B. C., Canada, Publ, by IEEE, $86 \mathrm{CH} 2276-4$, pp. 187-192

(Theoretical model and numerical results)

ANALYSIS OF LINEAR INDUCTION MOTORS USING A SIMPLIFIED SPACE HARMONIC TECHNIQUE Nonaka, S., and Fulll, N.

Proc., Int. Conf. Maglev and Linear Drives, May 14-16, 1986, Vancouver, B. C., Canada, Publ, by IEEE, $86 \mathrm{CH} 2276-4$, pp. $179-186$

(Theoretical model and numerical results)

TEST RESULT'S OF FULL-SCALE I MW LINEAR INDUCTION MOTOR ("U.LIM-AS") WITH PWM INVERTER

Fintescu, N. D., and Pascal, J. P.

Proc., Int. Cont. Maglev and Linear Drives, May 14-16, 1986, Vancouver, B. C., Canada, Publ. by IEEE, $86 \mathrm{CH} 2276-4$, pp. 165-170

(Introduction and test results)

THRUST AND LEVITATION FORCE CHARACTERISTICS OF LINEAR SYNCHRONOUS MOTORS

Sallo, T.

Proc., Int. Cont. Maglev and Linear Drlves, May 14-16, 1986, Vancouver, B. C., Canada, Publ. by IEEE, 86CH2276-4, pp. 157-164

(Theoretical model and numerical results)

A LINEAR SYNCHRONOUS UNIPOLAR MOTOR FOR INTEGRATED MAGNETIC PROPULSION AND SUSPENSION

Gilllland, A. G., and Pearson, G. W.

Proc., Int. Conf. Maglev and Linear Drives, May 14-16, 1986, Vancouver, B. C.., Canada, Publ. by IEEE, 86CH2276-4, pp. 149-155

(Theoretical and test results)

DESIGN OF SINGLE-SIDED LINEAR INDUCTION MOTORS FOR URBAN TRANSIT

Nonaka, S., and Higuchi, T.

Proc., Int. Cont. Maglev and !Inear Drives, May 14-16, 1986, Vancouver, B. C., Canada, Publ, by IEEE. 86CH2276-4, pp. $141-148$

(Theoretical model with numerical results)

OPERATIONAL EXPERIENCE WITH A LIM-DRIVEN TRANSIT SYSTEM

Gibbon, M. A., and Parker, J.H.

Proc., Int. Cont. Maglev and Linear Drives, May 14-16, 1986, Vancouver, B. C., Canada, Publ. by IEEE, $86 \mathrm{CH} 2276-4$, pp. $135-140$

(Test results)

LINEAR SYNCHRONOUS UNIPOLAR MOTOR (LSUM) DEVELOPMENT REPORT

Gilliland, R. G., and Pearson, G. W.

Frepared by Boeing Aerospace Co. for U.S. Dept. of Transp., Urban Mass Transp. Administration Rep. UMTA-WA-06-0014-086-2, Dec. 1986 
THE LONG STATOR PROPULSION SYSTEM OF THE TRANSAAPIO - DEVELOPMENT PROSPEOT'S UNTIL SERVICE MATURITY

Frledrioh, $F_{1 ;}$ Drelmann, K,i Lelstllkow, $F$.

Proo. Int. Cont. Maglev and Linear Drives, Las Vegas, Nev., USA, May 19-21, 1987; Publ. by IEEE, $87 \mathrm{CH} 2443-0$, pp. 171.180

(Status report, Including power supply)

THE MAGNETIC ELEVATOR FOR SOLIDS (MES): A TUBULAR LINEAR RELUCTANCE MOTOR Wallace, $A, K$, and Ranawake, U.A.

Proc., Int. Conf. Maglev and Linear Drives, Las Vegas, Nev., USA, May 19-21, 1987, Publ, by IEEE, 87CH2.443-0, pp. 45-51

THE SWITCH RELUCTANCE MOTOR AS A LOW-SPEED LINEAR DRIVE

Adamlak, K.; Barlow, D.; Choudhury, C. P.; Cusack, P.M.; of al.

Proc., Int. Cont. Maglev and Linear Drives, Las Vegas, Nev., USA, May 19-21, 198\%, Publ. by IEEE, $87 \mathrm{CH} 2443-0$, pp. $39-43$

THE SERIES CONNECTION OF SHORT STATOR LINEAR INDLICTION MOTORS FOR INTERCITY TAANSIT

Noriaka, S., and Fujili, N.

Proc., Int. Cont. Maglev arid Linear Drives, Las Vegas, Nev., USA, May 19-21, 1987, Publ. by IEEE, $87 \mathrm{CH} 2443 \cdot 0$, pp. 23-29

TRANSIENT OPERATION OF A LINEAR INDUCTION MOTOR

Gentlle, $G_{\text {i }}$ Rotonidale, N.; Scararo, M.

Proc., Int. Cont. Maglev and Linear Drives, Las Vegas, Nev., USA, May 19-21, 198\%, Publ. by IEEE, $87 \mathrm{CH} 2443-0$, pp. 7.11

DESIGN STRATEGY OF SINGLE-SIDED LINEAR INDUCTION MOTORS FOR PROPULSION OF

VEHICLES

Nonaka, S., and Higuchil, T.

Proc., Int. Conf. Maglev and I.Inoar Drives, Las Vegas, Nev., USA, May 19-21 1987, Publ. by IEEE, $87 \mathrm{CH} 2443-0$, pp. $1-5$

ELEIMENTS OF LINEAR INDUCTION MOTOR DESIGN FOR URBAN TRANSIT

Nonaka, S., and Higuchi, T.

IEEE Trans. Magn., Vol. MAG-23, No.5, Sept. 1987, pp.3002-3004

(NTIS No. 88.07 07691)

COMPAAISON OF SHOAT PRIMAAY LINEAA MACHINES FOA HIGH.SPEED MAGLEV VEHICLES

Eastham, J. F.; Balchin, M. J.; Podger, D.; Coles, P. C.

IEEE Trans. Magn., Vol. MAG-23, No. 5, Sept. 1987, pp.2338-2343

(NTIS No. 88-07 07482)

PEVIEW OF RECENT PROGRESS IN LINEAR MOTORS

Mclean, G, W.

IEE Proc. Part B, Vol. 135, No. 6, Nov. 1988, pp. 380-416

(NTIS No. 89-03 02293)

SIMULATION OF HEAVE MOTION OF CONTROLLED-PM LSM TYPE TA 06 USING A DECENTRALIZED CONTROL MODEL

Yohida, $K_{\text {, }}$ and Nakajlma, $O$.

Electr. Eng. Jpn., Vol. 108, No. 4, July-Aug, 1988, pp. 113-119

(NTIS No. 89.06 03939) 
DESIGN OF SINGLE-SIDED LINEAR INDUC'TION MOTORS FOR URBAN TAANSIT

Nonaka, S., and Higuohl, T.

IEEE Trans. Veh. Teohnol., Vol, 37, No, 3, Aug. 1988, pp 167-173

(NTIS No. 89.08 07996)

\section{DEVELOPMENT OF A MAGNETICALLYY SUSPENDED STEPPING MOTOA FOR CLEAN-HOOM}

TRANSPORTATION AND SAMPLE HANDING

Higuohl, $T$, and Kawakatsu, $H$.

Proo., 11th Int. Cont. Magnetloally Loviltated Syst, and Linear Drlves, July 7-11, 1989, Yokohama, Japan, Publ, by IEE Jpn, pp. 363-368

DEVELOPMENT OF THE TRAINSPORT SYSTEM WITH PM TYPE LPM

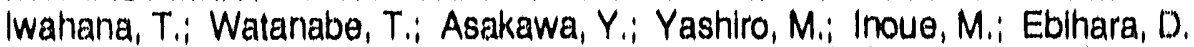

Proo., 11 th Int. Conf. Magnetloally Leviltated Syst, and Linear Drives, July 7-11, 1989, Yokohama, Japan, Publ, by IEE Jpn., pp. 357-362

TESTING MACHINE OF HYDRODYNAMIC FORCES USING LINEAR MOTOR

Kawanishl, T.; Takagl, N.; Kato, T.; Karita, J.; Takakado, Y.

Proc., 11th Int. Cont, Magnetlcally Leviltated Syst. and Linear Drlves, July 7-11, 1989, Yokoharna, Japan, Publ, by IEE Jpn, pp, 351-356

A NOVEL CONTROL SCHEME OF A LINEAF INDUCTION MOTOR

Koseki, T.; Onsakl, H.; Masada, E.

Proc., 11 th Int. Conf. Magnetically Levilated Syst. and Linear Drives, July 7-11, 1989, Yokohama, Japan, Publ. by IEE Jpn., pp. 345-350

ON THE REDUCTION OF ENERGY CONSUMPTION OF LINEAR INDUCTION MOTORS FOR URBAN TRANSIT

Nonaka, $S_{\text {., }}$ and Higuchi, $T$.

Proc., 11 th Int. Conf. Magnetically Levitated Syst, and Linear Drlves, July 7-11, 1989, Yokohama, Japan, Publ, by IEE Jpri., pp. 333-338

THE ASPECTS OF DESIGN OF SINGLE-SIDED LINEAPINDUCTION MOTORS FOR TRANSPORT AND INDUSTRIAL APPLICATIONS

Gleras, J.F.

Proc., 11th Int. Cont. Magnetically Levitated Syst, and Linear Drives, July 7-11, 1989, Yokohama, Japan, Publ. by IEE Jpn., pp. 321-326

CHARACTERISTICS OF TUBULAR LINEAR INDUCTION MOTOR ENERGIZED BY OPTIMIZED PRIMARY CURRENT

Yamamura, $T_{\text {.; }}$ Yokol, $T$.; Ishlyama, $A_{\text {.; }}$ Numata, H.; Kohyama, H.; Onukl, T

Proc., 11th Int. Cont. Magnetlcally Levitated Syst, and Linear Drives, July 7-11, 1989, Yokohama, Japan, Publ. by IEE Jpn., pp. 223-228

STUDY OF NOFIMAL FORCE REDUCTION TYPE OF LINEAR SYSCHNONOUS MOTOR Miyashita, K.; Kanazawa, $H_{\text {.; }}$ Nihel, $H_{\text {.; }}$ Klwakl, $H_{\text {. }}$

Proc., 11 th int. Cont. Magnetlcally Levitated Syst, and Linear Drives, July 7-11, 1989, Yokohama, Japan, Publ. by IEE Jpn., pp. 217-221

EXPERIMENTAL RESULTS OF SINGLE SIDED L.I.M.

Im, D. H.; Park, E. C.; Kim, G. T.

Proc, 11 th Int. Conf. Magnetioally Levitated Syst, and Linear Drives, July 7-11, 1989, Yokoharna, Japan, Publ. by IEE Jpn., pp. 209-216

STUDY OF LINEAR RELUCTANCE MOTOR FOR ELECTROMAGNETIC LEVITATION SYSTEM

Yamaguchi, $H_{1}$, and Yamamura, $S$.

Proc., 11 th Int. Conf. Magnetically Levitated Syst. and Linear Drives, July 7-11, 1989, Yokohama, Japan,

Publ. by IEE Jpn., pp. 197-202 
THE SYNCHRONOUS LONG-STATCA PROPULSION SYSTEM FOR TRANSRAPID - PRESENT STATE OF DEVELOPMENT .

Friedrich, A.; Elkermann, J.; Ruppel, J.

Proc., 11th int. Cont. Magnelloally Levitated Syst, and Linear Drives, July 7.11, 1989, Yokohama, Japan, Publ. by IEE Jpn., pp. 147-154 


\title{
6 Integrated Magnetic Suspension, Plopulsion, and Guidance Systems
}

\author{
Danby, G.T., and Powell, J. R. \\ Borcherts, R. H.; Davis, L. C.; Reitz, J. R.; Wilkie, D. F. \\ IEEE Proc., Vol. 61, No. 5, May 1973, pp. 569-578 \\ (TRIS No. 046395 DA) \\ DESIGN PRINCIPLES FOR MA "NETIC LEVITATION \\ Thornton, R. D. \\ IEEE Proc., Vol. 61, No. 5, May 1973 \\ (TRIS No. 046396 DA)
}

INTEGRATED SYSTEMS FOR MAGNETIC SUSPENSION AND PROPULSION OF VEHICLES

Applied Superconductivity Conf., May 1-3, 1972, pp. 120-126, IEEE Pub. No. 72CH0682-5-TABSC.

BASELINE SPECIFICATIONS FOR A MAGNETICALLY SUSPENDED HIGH-SPEED VEHICLE

CHARACTERISTICS OF SUPERCONDUCTIVE MAGNETIC SUGPENSION AND PROPULSION FOR HIGH-SPEED TRAINS

Iwamoto, $M_{1}$, and Yamada, $T$.

IEEE Proc., Vol. 61, No. 5, May 1973

(TRIS No. 047000 DA)

PERFORMANCE OF MAGNETIC SUSPENSIONS FOR HIGH-SPEED VEHICLES OPERATING OVER FLEXIBLE GUIDEWAYS

Katz, R. M.; Nene, V. D.; Ravera, R. J.; Skalski, C. A.

Intersoc. Cont. on Transp., Denver, Colo., USA, Sept. 23-27, 1973, Report No. 73-ICT-89

(TRIS No. 051415 DA)

\footnotetext{
ANALYSIS OF A COMBINED ATTRACTION-MAGLEV-PROPIJLSION SYSTEM FOR A HIGH SPEED VEHICLE

Muhlenberg, J. D., and Nene, V.D.

US Fed. Railroad Admin. Rep. FRA-OR\&D 75-61, March 1975, 45pp., Location of Work - MITRE Corp, Mclean, Va.

(NTIS No. 75-12 06147)
}

CONCEPTUAL DESIGN OF A MAGLEV HSGT SYSTEM

Pons, R. L., and Clark, T. B.

Intersoc. Conf. on Transp., Atlanta, Gaa, USA, July 14-18, 1975, ASME Pap. No. 75-ICT-2, 12pp.,

(NTIS No. 75-12 01553)

REPULSIVE LEVITATION AND PROPULSION

Yamashita, $\mathrm{H}$.

Q. Rep. Railw. Tech. Res. Inst., Vol. 17, No. 4, Dec. 1976, pp. 157-165

(TRIS No. 156236 DA) (Principles, concepts, and experimental results)

CHARACTERISTICS OF SUPERCONDUCTING MAGNETIC SUSPENSION AND GUIDANCE ON LOOP TRACKS

Iwahana, $T$.

Q. Rep. Railw. Tech. Res. Inst., Vol. 17, No. 4, Dec. 1976, pp. 178-181

(TRIS No. 156240 DA) (Theoretical and experimental results)

MECHANICAL SUSPENSION VEHICLE WITH AN ACTIVE GUIDE-WAY

Weh, $H_{\text {.; }}$ Mosebach, $H_{\text {.; }}$ Deleroi, W.

2nd Int. Hovering Craft, Hydrotoil and Adv. Trans. Syst. Conf., Amsterdam, Netherlands, May 17-20 1976, pp. 101-109, Location of the work - Tech. Univ., Braunschweig, Germany, ivo. -vं 1 igu

(NTIS No. 77-03 04109) 
SUPERCONDUCTING PADDLEWHEEL AS AN INTEGRATED PROPULSION LEVITATION MACHINE FOR HIGH GROUND TRANSPORTATION

Borcherts, R. H., and Davis, L. C.

Electr. Mach. Electromech., Vol.3, No. 3-4, April-June 1979, pp. 341-355

(Niris No. 79-08 01870)

ANAL,YTICAL AND DESIGN ASPECTS OF MAGNETICALLY SUSPENDED VEHICLES

Sinha, P. K.

Automatica, Vol. 15, No. 5, Sept. 1979, pp. 539-552

(NTIS No. 80-02 05326)

MAG-TRANSIT DEVELOPMENT AT BOEING

Gilliland, R. G.

29th IEEE Veh. Tectinol. Conf., Arlington Heights, III., USA, March 27-30, 1979, Conf. Rec. of Pap., Cat. No. $79 \mathrm{CH} 1378-9 \mathrm{VT}$

(NTIS No. 79-09 07445)

INTEGRATED MAGNETIC SUSPENSION AND PROPULSION OF GUIDED GROUND

TRANSPORTATION VEHICLES WITH A SLIM

Katz, R. M.; Eastham, A. R.; Dawson, G. E.; Atherton, D. A.; Schwalm, C. L.

IEEE Trans. Magn., Vol. MAG-15, No.6, Nov. 1979, pp. 1437-1439

(NTIS No. 81-08 03246)

"SPLIT-TRACK" SYSTEM OF ELECTROMAGNETIC LEVITATION FOR HIGH SPEED TRANSPORT Mahtani, J. L.; Rakels, J. H.; Rhodes, R.G.

Proc. 8th Int. Cryogenic Eng. Cont., Genoa, Italy, June 3-6, 1980

(TRIS NO. 341945 DA)

CONTROLLED PERMANENT MAGNET (CPM) CONFIGURATIONS GENERATING FORCES FOR LIFT, GUIDANCE AND THRUST

May, $H$.

Proc. Int. Conf. Cybern. Soc., Cambridge, Mass., USA, Oct.8-10 1980, Publ. by IEEE (Cat No.

80CH1555-2), Piscataway, N.J., 1980, pp.793-800

(NTIS No. 81-05 04122)

ACTIVITIES OF MBB IN THE FIELD OF MAGNETIC LEVITATION FOR HIGH SPEED GROUND TRANSPORTATION SYSTEMS

Bohn, G.

Proc. Int. Conf. Cybern. Soc., Cambridge, Mass., USA, Oct.8-10 1980, pp. 775-779

(NTIS No. 81-05 04119)

MAGNETIC LEVITATION FOR RAIL TRANSPORT

Rhodes, R. G., and Mulhall, B. E.

Clarendon Press, Oxford, United Kingdom, 1981

(Book, 102 p.)

DESIGN OF A MAGNETICALLY LEVITATED VEHICLE

Sinha. P. K.

IEEE I rans. Magrı, Vol. MAG-20, No.5, Sept.1984, pp. 1672-1674

(NTIS No. 85-07 10168)

MAGNETIC LEVITATION IN LINEAR PROPULSION MACHINES

Schieber, D.

J. Franklin Inst., Vol.317, No.3, Mar. 1984, pp. 171-181

(NTIS No. 84-06 03042) 
DESIGN CONCEPT AND COMPARATIVE PERFORMANCE OF AN ELECTRODYNAMIC MAGLEV TRANSPORTATION SYSTEM FOR THE TORONTO-MONTREAL CORRIDOR OF CANADA Hayes, W. F., and Tucker, H. G.

Inst. Mech. Eng., IMechE C400/84, 1984, pp. 137-147

INTEGRATED MAGNETIC PROPIILSION AND SUSPENSION SYSTEM TECHNOLOGY

Gilliland, R. G., and Basic, J. J.

Proc., Int. Corit. Maglev Transport '85, Sept. 17-19, 1985, Keidanren Kaikan, Tokyo, Japan, Pur I. by IEE Japan, pp. 145-154

(Theoretical discussion)

CRITERIA FOR THE EFFFCTIVENESS OF A LINEAR TRACTION DRIVE AND MAGNETIC SUSPENSION IN TERRESTRIAL TRANSPORTATION

Bakhvalov, Yu. A.; Bocharov, V. I.; Kozachenko, E. V.; Kuprianov, Yu. V.; Pavlyukov, V. M.

Sov. Electr. Eng., Vol.57, No.4, 1986, pp. 52-57

(NTIS No. 87-12 06580)

NEW MAGLEV SYSTEM FOR MAGNETICALLY LEVITATED CARRIER SYSTEM

Morishital, M.; Azukizawa, T.; Kanda, S.; Tamura, N.; Yokoyama, T.

Proc., Int. Cont. Maglev and Linear Drives, May 14-16, 1986, Vancouver, B. C., Canada, Publ. by IEEE, 86CH2276-4, pp. 199-204

(Theoretical analysis and design including control scheme)

ELECTROMAGNETIC LEVITATION SYSTEM BY MEANS OF SALIENT POLE TYPE MAGNETS AND TRAPEZOIDAL LAMINATED RAIL:

Yamaguchi, $H_{\text {., }}$ and Yamamura, $S$.

Proc., Int. Conf. Maglev and Linear Drives, Las Vegas, Nev., USA, May 19-21, 1987, Publ. by IEEE, 87CH2443-0, pp. 79-86

CHARACTERISTICS OF ARMATURE CIRCUIT TAKING THE ELECTROMAGNETIC CHARACTERISTICS OF THE COMBINED LEVITATION AND GUIDANCE SYSTEM USING GROUND COILS ON THE SIDE WALL OF THE GUIDEWAY INTO CONSIDERATION

Nakamichi, $Y$.; Toda, $H$.; Ikeda, $H$.

Proc. 1990 National Convention of the Institute of Electrical Engineers (IEE) of Japan

SURGE ANALYSIS OF MAGLEV COIL FOR GUIDANCE AND PROPUL.SION

Ema, S., and Ajiki, K.

Proc. 1990 National Convention of the Institute of Electrical Engineers (IEE) of Japan

INSIDE SURGE CHARACTERISTICS OF MAGLEV COIL FOR GUIDANCE AND PROPULSION

Shiraishi, H.; Ajiki, K.; Ema, S.

Proc. 1988 National Convention of the Institute of Electrical Engineers (IEE) of Japan

EQUIVALENT CIRCUIT OF MAGLEV COIL FOR GUIDANCE AND PROPULSION

Ema, S.; Ajiki, K.; Shiraishi, $H$.

Proc. 1988 National Convention of the Institute of Electrical Engineers (IEE) of Japan 
$=$
$=$
$=\overline{=}$

吾 


\section{Vehicle Dynamics}

DYNAMIC CHARACTERISTICS AND CONTROL REQUIREMENTS OF ALTERNATIVE MAGNETIC LEVITATION SYSTEMS

Wilkie, D. F., and Borcherts, R. H.

ASME Paper No. 73-ICT-17 from Meet., Sept. 23-27, 1973, 17p, (NTIS No. 73-10 01714)

DYNAMICS OF MAGNETIC LEVITATION SUSPENSION SYSTEMS FOR HIGH SPEED GROUND

VEHICLES

Millner, J. L.

ASME AMD, Vol. 5, 1973, for Meet., Detroit, Mich., Nov. 1973, pp. 79-86

(NTIS No. 74-04 00956)

CHARACTERISTICS OF THE RIDE QUALITY OF SUPERCONDUCTING MAGNETIC LEVITATION TEST

VEHICLE

Twahana, $T$., and Kuzuu, $T$.

Proc. 5 th Int. Cryog. Eng. Conf., Kyoto, Japan, May 7-10, 1974, pp.106-107

(TRIS No. 130899 DA)

(Experimental results)

DYNAMIC PERFORMANCE OF THE SRI MAGLEV VEHICLE

Cotley, H. T., et al.

IEEE Trans. Magn., Vol. MAG-10, No. 3, Sept. 1974, pp. 451-457

AN EVALUATION OF THE DYNAMICS OF A MAGNETICALLY LEVITATED VEHICLE

Cottey, H. T., et al.

Prepared by SRI for US Dept. of Transp., Federal Railway Administration, Rep. FRA (JRD\&D-74-41, March 1974

(NTIS No. PB-236671)

STABILITY OF MAGNETICALLY LEVITATED VEHICLES OVER A SPLIT GUIDEWAY

Howell, J. P.; Wong, J. Y.; Rhodes, R. G.

IEEE Trans. Magn., Vol. MAG-11, pp. 1487-1489

CHARACTERISTICS OF INDUCTIVE MAGNETIC LEVITATION SYSTEM WITH MONOPOLAR TRAIN LOOPS

Okuma, S., and Arnemiya, $Y$.

Electr. Eng. Jpn., Vol. 98, No. 2, March 1976, pp. 84-91

(TRIS No. 311044 DA)

PASSIVE SECONDARY MAGNETIC DAMPING FOR SUPERCONDUCTING MAGLEV VEHICLES

Atherton, D. L., et al.

J. Appl. Phys., Vol. 47, No.10, Oct. 1976, pp. 4643-4648

(NTIS No. 77-02 04825)

PERFORMANCE AND STABILITY CHARACTERISTICS OF AN ELECTRODYNAMICALLY LEVITATED VEHICLE OVER A SPLIT GLIIDEWAY

Wong, J. Y.; Howell, J. P.; Rhodes, R. G.; Mulhall, B. E.

ASME Pap., No. 76-Aut-HH 1976, 9 pp., Location of work- Univ. of Warwick, England

(NTIS NO. 77-03 04040)

DYNAMICS AND CONTROL OF COMBINED LIFT-GUIDANCE FERROMAGNETIC VEHICLE SUSPENSIONS

Limbert, D. A.; Richardson, H. H.; Wormley, D. N.

Proc. Jt. Autom. Control Cont., San Francisco, Calif., June 22-24, 1977, Publ. by IEEE (Cat. No. 77 Ch 1220-3cs), New York, N.Y., 1977, Vol. 1, pp. 435-440

(NTIS No. 78-01 02681) 
LOW-SPEED VEHICLE DYNAMICS AND RIDE QUALITY USING CONTROLLED D.C.

ELECTROMAGNETS

Jayawant, B. V., and Sinha, P. K.

Automatica Vol. 13, No. 6, Nov. 1977, pp. 605-610

(NTIS No. 78-04 04277)

STUDIES ON PASSIVE MAGNETIC DAMPING IN THE REPULSIVE MAGNETIC LEVITATION SYS TEM Fujiwara, S.

Q. Rep. Railw. Tech. Res. Inst., Vol. 19, No. 4, Dec. 1978, pp. 191-192

(TRIS No. 300730 DA), (Experimental results)

DYNAMICAL ASPECTS OF PASSENGER CARAYING VEHICLES USING CONTROLLED D.C.

ELECTROMAGNETS

Jayawant, B. V.

Dyn. Veh. on Roads and on Tracks, Proc. 5th Veh. Syst. Dyn. (VSD) Syrnp., Sept. 19-23 1977, Publ. by

Swets \&Zeitlinger, Amsterdam, Netherlands, 1978, pp. 343-356

(NTIS No. 79-03 01020)

ELECTROMAGNETIC PROPERTIES OF REPULSION LEVITATION SYSTEM IN THE PRESENCE OF SPATIAL OSCILLATIONS OF THE FIELD SOURCE

Mikintichev, A. A.; Kim, K. I.; Vasil'ev, S. V.

Power Eng. (New York), Vol. 16, No. 4, 1978, pp. 66-73

(NTIS No. 79-10 06157)

NONCONSERVATIVE INSTABILITIES IN ELECTRODYNAMIC MAGNETIC LEVITATION OF VEHICLES Moon, $F$.

Int Serninar on Superconductive Magnetic Levitated Train, Mlyazaki, Japan, Nov. 1978, pp. 108-112.

ELECTRODYNAMICS OF FINITE WIDTH GUIDEWAY MAGLEV SYSTEMS IN AN INTEGRAL EQUATION FORMULATION

Urankar, L..

Siemens Forsch Entwicklungsber Res. Dev. Rep., Vol. 8, No. 4, 1979, pp. 204-208

(NTIS No. 80.01 02217)

DYNAMICS OF MAGNETICALLY SUSPENDED VEHICLES

Sinha, P.K.

Trans. Inst. Meas. Control, Vol. 1, No. 1, Jan-March 1979, pp. 57-64

(NTIS No. 80-02 05861)

DYNAMICS SIMULATION FOR A HIGH SPEED MAGNETICALLY LEVITATED GUIDED GROUND

VEHICLE

Cherchas, D. B.

J. Dyn. Syst. Meas. Control Trans. ASME, Vol. 101, No. 3, Sept. 1979, pp. 223-229

(NTIS No, 80-02 01228)

CONTROLLED DYNAMIC CHARACTERISTICS OF FERROMAGNETIC VEHICLE SUSPENSIONS

PROVIDING SIMULTANEOUS LIFT AND GUIDANCE

Limbert, D. A.; Richardson, H. H.; Wormley, D. N.

J. Dyn. Sysi. Meas. Control Trans. ASME, Vol. 101, No. 3, Sept. 1979, pp. 217-222

(NTIS No. 80-02 01227)

MAGNETIC DAMPING CHARACTERISTICS OF MAGNETICALLYY SUSPENDED ULTRA.HIGH.SPEED VEHICLES

Takaı 1, I., and Ogiwara, $H$.

Electr. Eng. Jpn., Vol. 98, No. 5, Sept.-Oct. 1978, pp. 14-23

(NTIS No. 80-07 03488) 
DAMPING CHARACTERISTICS OF THE REPULSIVE MAGNETIC LEVITATION VEHICLE

Fujiwara, $\mathrm{S}$.

Q. Rep. Railw. Tech. Res. Inst. (Tokyo), Vol. 21, No. 1, March 1980, pp 49-52

(NTIS No. 81-0107202)

DYNAMIC RESPONSE OF MAGNETICALLY LEVITATED FLEXIBLE VEHICLE TO RANDOM TRACK IRREGULARITIES

Milyamoto, $M$.

Q. Rep. Railw. Tech. Res. Inst. (Tokyo), Vol. 21, No. 1, March 1980, pp 44-48

(NTIS No. 81-01 07201)

VERTICAL UNSTABLE STABILITY OF ELECTRODYNAMIC SUSPENSION OF HIGH-SPEED GROUND TRANSPORT

Baiko, A. V.; Voevodskil, K. E.; Kochetkov, V.M.

Cryogenics, Vol. 20, No. 5, May 1980, pp 271-276

TRIS No. 341943 DA)

VEHICLE-GUIDEWAY DYNAMICS OF A HIGH-SPEED MAGLEV TRAIN

Meisinger, $R$.

Proc. Int. Conf. Cybern Soc., Cambridge, Mass., USA, Oct. 8-10, 1980, pp. 1028-1035

(NTIS No. 81-05 04163)

DYNAMICS OF MAGLEV VEHICLES ON ELEVATED GUIDEWAYS

Popp, K.

Proc. Int. Conf. Cybern Soc., Cambridge, Mass., USA, Oct. 8-10, 1980, pp. 1018-1027

(NTIS No. 81-05 04162)

DYNAMIC CHARACTERISTICS OF A LONG TRAIN OF EML VEHICLES OVER ELEVATED FLEXIBLE GUIDEWAYS

Nagai, $M_{\text {., }}$ and Iguchi, $M$.

Bull. JSME, Vol.23, No. 184, Oct. 1980, pp. 1663-1669

(NTIS No. 81-07 02336)

RIDE QUALITY ANALYSIS OF REPULSIVE-TYPE MAGNETICALLY LEVITATED VEHICLES

Tsuhamoto, $O$., and Iwasa, $Y$.

Electr. Eng. Jpn., Vol. 99, No. 5, Sept.-Oct 1979, pp. 76-85

(NTIS No. 82-01 06043)

OPTIMIZATION OF MAGNET SUSPENSION AND ANALYSIS OF VEHICLE DYNAMICS

Poberezhskii, L. P.; Renzhin, G. I.; Tyurin, Yu. V.

Power Eng. (New York), Vol. 19, No. 1, 1981, pp. 100-106

(NTIS No. 82-05 02693)

ELECTROMAGNET CONTROL IN HIGH-SPEED TRANSPORT SUSPENSION SYSTEMS

Katsan, T. I.; Lebedev, V. G.; Mytarev, A. I.

Power Eng. (New York), Vol. 19, No. 1, 1981, pp. 95-99

(NTIS No. 82.05 02692)

DYNAMICS OF MAGNETIC-SUSPENSION TRANSPORT ROLLING STOCK

Baibakov, S. N.; Rabinovich, B. I.; Sokolov, Yu. D.

Power Eng. (New York), Vol. 19, No. 1, 1981 pp. 81-88

(NTIS No. 82-05 02690)

MAGNETIC DAMPING AND STIFFNESS COEFFICIENTS IN SUPERCONDUCTING MAGLEV SYSTEM WITH SHEET GUIDEWAYS

Yoshida, $K_{\text {, }}$ and Takakura, $M$.

Electr. Eng. Jpn., Vol. 99, No. 6, Nov.-Dec. 1979, pp. 90-97

(NTIS No. 82.07 04186) 
OBSERVATIONS OF DYNAMIC INSTABILITIES IN MAGNETICALLY LEVITATED MODELS Chu, D., and Moon, F. C.

2nd Int. Seminar on Superconductive Magnetic Levitated Train, Mlyazakl, Japan, Nov. 1982, pp. 136-141 (Experimental analysis)

MAGLEV DYNAMICS AND RIDE QUALITY: PAST, PRESENT AND FUTURE

Borcherts, R. H.

2nd Int. Seminar on Superconductive Magnetic Levitated Train, Miyazaki, Japan, Nov. 1982, pp. 133-135 (Introduction)

VIBRATION PROBLEMS IN MAGLEV VEHICLE DYNAMICS

Iguchi, $M$.

2nd Int. Seminar on Superconductive Magnetic Levitated Train, Mlyazakl, Japan, Nov, 1982, pp. 127-132 (Computer simulations)

DYNAMICS OF HIGH-SPEED VEHICLES

Schlehlen, W. O.

Course Lect. Int. Cent. Mech. Scl., No. 274, Dyn. High-Speed Veh., Udine, Italy, 1981, Publ. by

SpringerVerlag, Vienna, Austria and New York, NY, USA, 1982, 395pp.

(NTIS No. 86-02 08818)

DYNAMIC INSTABILITIES IN MAGNETICALI.Y LEVITATED MODELS

Chu, D., and Moon, F. C.

J. Appl. Phys., Vol. 54, No. 3, March 1983, pp. 1619-1625

(NTIS No. 83-07 06560)

SUSPENSION BOUNCE RESPONSE OF CANAUIAN MAGLEV VEHICLE UNDER GUIDEWAY EXCITATIONS. PART 1: DETERMINISTIC ANALYSIS

Kotb, M.; Sanker, T. S.; Samaha, M.

J. Vib. Acoust. Stress Rellab. Des., Vol. 105, No. 1, Jan. 1983, pp. 104-111

(NTIS No. 83-09 07780)

SUSPENSION BOUNCE RESPONSE OF CANADIAN MAGLEV VEHICLE UNDER GUIDEWAY EXCITATIONS. PART 2: STOCHASTIC MODELING ANAL.YSIS

Kotb, M.; Sanker; T. S.; Samaha, M.

J. Vib. Acoust. Stress Reliab, Des., Vol. 105, No. 1. Jan. 1983, pp. 261-266

(NTIS No. 83-09 07803)

DYNAMIC INSTABILITY OF A TRACK STRUCTURE

Bagryantsev, V. I., and Tyurin, Y. V.

Power Eng. (New York), Vol. 22, No. 1, 1984, pp. 16-21

(NTIS No. 85-01 00116)

FEASIBILITY OF PASSIVE DAMPING FROM MIXED-MU LEVITATION

Oraee Mirzamani, S. J.; Asher, G. M.; Paul, R. J. A.

IEEE Trans. Magn., Vol. MAG-20, No. 5, Sept. 1984, pp. 1681-1683

(NTIS No. 85-07 10171)

DYNAMICS BEHAVIORS OF MAGNETIC WHEEL

Fujisaki, K., and Masada, E.

IEEE Trans. Magn., Vol. MAG-20, No. 5, Sept. 1984, pp. 1678-1680

(NTIS No. 85-07 10170)

CONTROL LAW DESIGN AND DYNAMIC EVALUATIONS FOR A MAGLEV VEHICLE WITH A COMBINED I.IFT AND GUIDANCE SUSPENSION SYSTEM

Kortuem, W., and Uizt, A.

J. Dyn. Syst. Meas. Control Trans. ASME, Vol. 106, No. 4, Dec. 1984, pp. 282.292

(NTIS No. 85-07 00969) 
EL.ECTRODYNAMIC FORCE CHARACTERISTICS OF THE SPLIT-TRACK MAGLEV SYSTEM

Mahtanl, J. L,; and Rhodes, R. G.

Journal de Physique, supplement au no. 1, C1-747-751 (1984).

PROGRESS OF RESEARCH WORKS ORIENTED TOWARDS MAGNETIC HOVER TRAIN ON ELECTRODYNAMIC BASIS

Hochhaeusler, $P$.

Arch. Elektrotech. (Warsaw), Vol, 33, No. 1-2, 1984, pp. 343-348

(NTIS No. 86-04 06110)

MODE COUPLING IN MAGLEV VEHICLES

Sinha, P. K.

Proc., Int. Conf. Maglev Transport '85, Sept. 17-19, 1985, Keldanren Kaikan, Tokyo, Japan, Publ, by IEE, Japan, pp. 179-184

(Theoretical analysis)

GUIDIANCE DYNAMICS OF MIXED-MU LEVITATORS FOR MAGLEV VEHICLES

Mirzamani, S. J., and Orae日 Paul, R. J. A.

IEEE Trans. Magn., Vol. MAG-21, No. 6, Nov. 1985, pp. 2404-2407

(NTIS No. 86-08 11507)

SIMULATION OF RUNNING COUPLED RAIL CARS USING A CONTROL THEORY OF BOGIE TRUCK FOR DAMPING RAIL OSCILLLATION

Nakagawa, T.; Yamamura, S.; Nakanishl, K.

Electr. Eng. Jpn., Vol.106, No, 2, Mar.-Apr, 1986, pp. 131-138

(NTIS No. 86-11 09724)

ON THE FORCE DEVELOPMENT DURING OSCILLATIONS OF AN ELECTRODYNAMIC SUSPENSION Kochetkov, V. M., and Matin, V. I.

Power Eng. (New York), Vol. 24, No. 6, 1986, pp. 147-150

(NTIS No. 87.08 04358)

A STUDY OF CURVATURE RUNNING OF HSST VEHICLE

Hikasa, $Y_{\text {.; }}$ Iwaya, M.; Kusunoki, K.; Hosoda, $Y$.

Proc., Int. Conf. Maglev and Linear Drives, May 14-16, 1986, Vancouver, B. C., Canada, Publ. by IEEE,

86CH2276-4, pp. 127-134

(Computer simulations)

DYNAMIC INTERACTION BETWEEN PROPULSION AND SUSPENSION SYSTEM IN A MAGLEV

VEHICLE

Masada, E.; Fujisaki, K.; Suzuki, S.; Kawashima, M.

Proc., Int. Conf. Maglev and Linear Drives, May 14-16, 1986, Vancouver, B. C., Canada, Publ. by IEEE, 86CH2276-4, pp. $119-126$

(Theoretical and experimental results)

ELECTRODYNAMIC MAGLEV SYSTEM OPERATIONAL SAFETY CONSIDERATIONS

Hayes, W. F., and Tucker, H. G

Proc., Int. Conf. Maglev and Linear Drives, May 14 16, 1986, Vancouver, B. C., Canada, Publ. by IEEE, 86CH2276-4, pp. 107-117

(Theoretical model)

SOME STRUCTURAL. PROPERTIES OF THE ELECTROMAGNETIC SUSPENSION SYSTEM

Sinha, P. K.

Proc., Int. Conf. Maglev and Linear Drives, Máy 14-16, 1986, Vancouver, B. C., Canada, Publ. by IEEE, 86CH2276-4, pp. 101-106

(Theoretical model, suspension dynamics) 
SIMULATION OF THE DYNAMICS OF HIGH SPEED GROUND TRANSPORTATION VEHICLES WITH MEDYNA.POTENTIALS AND CASE STUDIES

Kortum, W.

Proc., Int. Cont. Maglev and Linear Drives, Las Vegas, Nev., USA, May 19-21, 1987, Publ. by IEEE, 87CH2443-0, pp. $99-112$

(Computer Simulations)

DYNAMICS OF THE PM TYPE LINEAR SYNCHRONOUS MOTOR FOR MAGNETICALLYY LEVITATED CARRIER VEHICLE

Hayafune, $K_{1}$, and Masada, $E$.

IEEE Trans. Magn, Vol. MAG-23, No. 5, Sept. 1987, pp. 2578-2580

(NTIS No. 88.07 07558)

DYNAMICS OF THE PHOPULISION AND LEVITATION SYSTEMS IN THE CONTROLLED-PM LSM

MAGLEV VEHICLE

Yoshida, $K_{\text {, }}$ and Umino, $T$.

IEEE Trans. Magn., Vol. MAG-23, No. 5, Sept. 1987, pp. 2353-2355

(NTIS No. 88-07 07486)

DYNAMICS BETWEEN THE RUNNING COUPLED VEHICLES AND FLEXIBLE RAIL OUT OF THE STANDARD TYPE

Nakagawa, $T$.

Proc., 1 th int. Cont. Magnetically Levitated Syst. and Linear Drives, July 7-11, 1989, Yokohama, Japan, Publ. by IEE Jpn., pp. 429-434

STABILIZATION FOR FLEXIBLE BEAM SYSTEM CONTFOLLED BY MAGNETIC SUSPENSION Matsumura, F.; Fujta, $M_{. ;}$Ozaki, Y.; Shimizu, $M$.

Proc., 11th Int. Conf. Magnetically Levilated Syst, and Linear Dilves, July 7-11, 1989, Yokohama, Japan, Publ. by IEE Jpn., pp. 423-428

ROBUST SERVO LEVITATION CONTROL. AND RUNNING SIMULATION OF CONTROLLED-PM LSM MAGLEV VEHICLES

Yoshida, K.; Nakashima, O.; Yoshida, K.

Proc., 11th Int. Cont. Magnetically Levitated Syst. and Linear Drives, July 7-11, 1989, Yokohama, Japan, Publ. by IEE Jpn., pp. 411.416

BOUNCING AND PITCHING OSCILLATIONS OF A MAGNETICALLY LEVITATED VEHICLE CAUSED BY GUIDEWAY ROUGHNESS (EXCITATION DUE TO NONLINEARITY OF MAGNETIC LIFT FOACE)

Yabuno, H.; Takabayashi, Y.; Yoshizawa, M.; Tsujioka, Y.

Proc., 11 th Int. Cont. Magnetically Levitated Syst. and Linear Drives, July 7-11, 1989, Yokohama, Japan, Publ. by IEE Jpn., pp. 405-410

OPTIMAL ACTIVE SUSPENSION TO IMPROVE THE DYNAMIC STABILITY OF" REPULSIVE MAGLEV SYSTEMS

Nagal, M.; Moran, A.; Tanaka, S.

Proc., 11th Int. Cont. Magnetically Levitated Syst. and Linear Drives, July 7-11, 1989, Yokohama, Japan, Publ. by IEE J.Jpn., pp. 399-404

DYNAMIC CHAFACTERISTICS OF URBAN TRANSIT LIM WITH FEED-BACK SPEED CONTROL Nonaka, S, and Fujili, N.

Proc., 11th Int. Conf. Magnetically Levitated Syst. and Linear Drives, July 7-11, 1989, Yokohama, Japan, Publ. by IEE Jpn., pp. 327-332 
A STUDY OF THE CHARACTEAISTICS OF THE AEFODYNAMICS OF" THE MAGNETICALLY LEVITATED TAANSPOATATION SYSTEM (MAGLEV)

Matsunuma, S.; Nagayarma, Y.; Kobayashl, $S$.

Proo, 11th Int. Cont. Magnetlcally Levitated Syst, and LInear Drives, July 7-11, 1989, Yokohama, Japan, Publ, by IEE Jphn., pp. 275-280

AEMO-ACOUSTIC, INVESTIGATIONS OF THE MAGNETIC TRAIN TRANSRAPID 06

Alscher, H.

Proc., 11th Int. Coill. Magnetically Levitated Syst, arid LInear Drives, July 7-11, 1989, Yokoharma, Japan, Publ, by IEE Jpn., pp. 269-274

DYNAMIC BEHAVIOUR OF THE MODULE \& SUSPENSION SYSTEM ON HSSTO5

Iwaya, $M$.

Proc., 11th Int. Cont. Magnetically Levitated Syst. and LInear Drives, July 7.11, 1989, Yokohama, Japan, Publ. by IEE Jpn., pp. 263-268 


\section{System Control and Simulations}

MEASURING AND CONTHOL SYSTEM FOR TESTING NEW COMPONENTS FOR GUIDED TAANSPOATATION SYSTEMS EMPLOYING MAGNETIC LEVITATION

Mandt, $K$.

Slemens Res., Vol. 41, No. 12, Dec. 1974, pp. 527-532

(NTIS No. 75.04 04069)

CONTROL OF A LINEAR SYNCHRONOUS MOTOR FOR MAGNETICALLY LEVITATED VEHICLES

Glbson, J.i Holtz, J.i Lingaya, S.

Proc, INFAC/ IFIP (Int. Found. for Inf. Process. ) / IFORS (Int. Fed. of Oper. Res, Soc.) Int. Symp.: Control in Transp. Syst, Columbus, Ohio, Aug. 9*13, 1976, Publ. by IFAC, 1976. Available from ISA, Piltsburgh,

Pa., pp. 143-152

(NTIS No. 77-04 06106)

SYNTHESIS OF A HIGH.SPEED TRACKED VEHICLE SUSPENSION SYSTEM - PART II: DEFINITION AND SOLUTION OF THE CONTROL PFOBLEM

Guenther, C. R., and Leondes, C, T.

IEEE Trans. Autom. Control, Vol. AC.2.2, No. 2, Aprll 1977, pp. 165.172

(NTIS No. 77-08 07198)

SYNTHESIS OF A HIGH-SPEED TRACKED VEHICLE SUSPENSION SYSTEM - PART I: PROBLEM STATEMENT, SUSPENSION STRUCTURE, AND DECOMPOSITION

Guenther, C. R., and Leondes, C. T.

IEEE Trans. Autom. Control, Vol. AC-22, No. 2, April 1977, pp. 158-165

(NTIS No. 77.08 07197)

SUSPENSION AND GUIDANCE CONTROL SYSTEM FOR A DC ATTRACTION MAGLEV VEHICLE. Goodall, R. M.

IEE Conf. Publ. (London) No. 142, 2nd Cont, on Adv, In Magn. Mater. and Appl., London, England, Sept. 1-3, 1976, pp. 100-103

(NTIS No. 77.09 01373)

CONTHOL ASPECTS OF A THACKED MAGNETIC LEVITATION HIGH SPEED TEST VEHICLE Goltzeln, E.; Brock, K. H.; Schneider, E.; Plefferl, J.

Automallica, Vol. 13, No. 3, May 1977, pp. 205-223

(NTIS No. 78-02 05925)

SIMULATION OF ROAD SURFACES FOR USE IN ANALOG COMPUTER STUDIES OF VEHIICLE SUSPENSION SYSTEMS

Kavarlagh, R. J.

Proc. of the 20th Midwes! jymp, on Clrcuils and Syst., Texas Tech. Univ., Lubbock, Texas, USA, Aug. 15 17, 1977, Puts, by Westein Perlodicals Co., North Hollywood, Calli., 1977, pp. 269-273 (NTIS No. 78-03 03,48)

ANAL.YTICAL AND DESIGN ASPECTS OF PASSENGER CARRYING VEHICLES USING CONTROLLED D. C. ELECTAOMAGNETIC SUSPENSION

Sinha, P. K.

4th IFAC Int. Symp. on Multivariable Technol. Syst., Prepr., Univ. of NB., Fredericaton, July 4-8, 1977, Publ. by Pergamon Press., Elmstord, N.Y, and Oxtord, England, 1977, pp. 573-581

(NTIS No. 78-10 07605) 
DESIGN OF OPTIMAL STATE-OBSEFVEAS AND ITS APPLICATION TO MAGLEV VEHICLE SUSPENSION CONTROL

Mueller, $P, C$.

4th IFAC Int. Symp, on Multivariable Technol, Syst, Prepr, Univ. of NB., Frederlcaton, July 4-8, 1977, Publ, by Pergamon Press., Elmstord, N.Y. and Oxford, England, 1977, pp. 175-182

(NTIS No. 78-10 07569)

\section{ANALOG SIMULATION OF MAGNETICALLY LEVITATED VEHICLES ON FLEXIBLE GUIDEWAYS} Melsinger, $R$.

IMACS (Int. Assoc, for Math and Comput, in Simul.) Symp. on Sirnul, of Control Syst, with Spec. Emphasls on Model and Redundancy, Sept. 27-29, 1978, Publ. by North-Holland Publ. Co., New York, N.Y., pp, 207-2.14

(NTIS No. 80-05 01130)

\section{GENERAL PURPOSE PROGRAM FOR THE SIMULATION OF VEHICLE-GUIDEWAY INTERACTION DYNAMICS \\ Duffek, W.; Kortuem, W.; Wallrapp, 0 .}

Dyn. Veh. on Roads and on Tracks, Proc. 5th Veh. Syst. Dyn. (VSD) Symp., Sept. 19-23, 1977, Publ, by Swets \& Zeltlinger, Amsterdam, Netherlands, 1978, pp, 104-126

(NTIS No. 79.03 01004)

OPTIMAL CONTROL OF ELECTROMAGNETIC LEVITATION SYSTEMS

Ohnishi, K.; Yamamura, S.; Hayashi, T.

Electr. Eng. In Jpn., Vol. 98, No. 2, March 1978, pp. 122-130

(TAIS No. 311045 DA)

\section{SIMULATION OF MAGLEV VEHICLES RIDING OVER SINGLE AND DOUBLE SPAN GUIDEWAYS} Melsinger, $R$.

Math. Comput. Simul., Vol. 21, No. 2, Aug. 1979, pp. 197-206

(NTIS No. 80.03 07721)

THEORY OF CONTROL OF ELECTROMAGNETICALLY LEVITATED BOGIE TRUCK

Yamamura, S.; Ohnishi, K.; Masada, E.

Electr. Eng. Jpn., Vol. 99, No. 6, Nov.-Dec. 1979, pp. 62.69

(NTIS No. 82-07 04183)

LOW SENSITIVITY CONTROL SYSTEMS FOR MAGLEV VEHICLES

Breinl, W.

Proc. Int. Conf. Cybern. Soc., Cambridge, Mass., USA, Oct. 8-10, 1980, pp. 786-792

(NTIS No. 81-05 04121)

ACTIVE-SYNCHRONIZATION CONTROL SYSTEM USED IN DC LINEAR MOTOR

Umemorl, T.; Matsuoka, K.; Matsul, K.; Otsubo, T.

IEEE POwer Eng. Soc. Summer Meet., Conf. Pap., Portland, Oregon, USA, July 26-31, 1981, Publ. by IEEE, 81 SM 310-2, 9 pp.

(NTIS No. 82-06 07610)

PROPUI.SION CONTROL SYSTEM FOR TEST VEHIICLE ML-500

Kolke, S.; Matsumaru, H.; Nakamura, K.; Yatsu, S.

Hitachl Pev., Vol. 30, No. 2, Aprll 1981, pp. 103-108

(NTIS No. 82-10 02139)

OPTIMIJM CONTROL THEORY OF A BOGIE-TRULCK FOR UAMPING RAIL OSCILLATION AND

SIMULATION FOR THE RUNNING COUPLED RAIL. CARS

Nakagawa, T., and Yamamura, $S$.

Proc., Irit. Cont. Maglev Transport '85, Sept. 17-19, 1985, Keldanren Kalkan, Tokyo, Japan, Publ. by IEE, Japan, pp. 173-178

(Theoretical analysis with numerical simulation) 


\begin{abstract}
A LINEAR INDUCTION MOTOR CONTROL SYSTEM FOR MAGNETICALLY LEVITATED CARRIER SYSTEM

Azukizawa, T.; Morishita, M.; Kanda, S.; Tamura, N.; Yokoyama, T.

Proc., Int. Conf. Maglev and Linear Drives, May 14-16, 1986, Vancouver, B. C., Canada, Publ. by IEEE, 86CH2276-4, pp. 205-209

(Theoretical and experimental analysis)
\end{abstract}

STUDY ON MAGLEV VEHICLE POSITION DETECTING SYSTEM USING THE FEEDING CIPC,!!" $S$ Ikeda, $H_{\text {., }}$ and Shimada, $K$.

Railw. Tech. Res. Inst., Railw. Tech. Res. Rep. N1318, March 1986, pp. 1-73

(TRIS No. 468826)

AUTOMATED OPERATIONS CONTROL SYSTEM FOR HIGH SPEED MAGLEV TRANSPORTATION Sichnieder, E.; Kraft, K. H.; Guckel, H.

Proc., Int. Conf. Maglev and Linear Drives, Las Vegas, Nev., USA, May 19-21, 1987, Publ. by IEEE, $87 \mathrm{CH} 2443-0, \mathrm{pp} .181-188$

(Theoretical model of system coritrol)

CONTROL SIMULATION OF RAILWAY SWITCH SYSTEM USING X-Y TYPE LINEAR INDUCTION MOTOR Ohira, Y.; Kawanishi, T.; Masada, E.

Proc., Int. Conf. Maglev and Linear Drives, Las Vegas, Nev., USA, May 19-21, 1987, Publ. by IEEE, $87 \mathrm{CH} 2443-0, \mathrm{pp}, 13-21$

OPTIMAL ROBUST SERVO SYSTEM DESIGN AND SIMULATION OF MAGNETIC LEVITATION SYSTEM IN CONTROLLED PERMANENT MAGNET LINEAR SYNCHRONOUS MOTOR VEHICLE

Yoshida, K., and Muta, $\mathrm{H}$.

Electr. Eng. Jpn., Vol.107, No. 4, July-Aug. 1987, pp. 122-129

(NTIS No. 88-05 01575)

CONTROL METHOD FOR A TWIST RESPONSE TYPE OF ELECTROMAGNETICALLY LEVITATED

TRUCK AND ITS EXPERIMENTS USING DIGITAL. CONTROL THEORY

Nakagawa, T.; Yamamura, $S$; ; Nakanishi, $K$.

Eletr. Eng. Jpn., Vol. 107, No. 5, Sept.-Oct 1987, pp. 94-101

(NTIS No. 88-08 05323)

RUNNING SIMULATION OF CONTROLLED-PM LSM TYPE HIGH-SPEED MAGLEV VEHICLE Yoshida, K., and Takagi, $T$.

Electr. Eng. Jpn., Vol. 108, No. 3, May-June 1988, pp. 131-139

(NTIS No. 89-03 02284)

CONTROL CHARACTERISTICS OF A TRANSPORTATION SWITCH USING X-Y LINEAR INDUCTION MOTOR

Ohira, $Y_{\text {,; }}$ Kawanishi, T.; Masada, E.

Electr. Eng. Jpn, Vol. 108, No. 3, May-June 1988, pp. 121-130

(NTIS No. 89-03 02283)

DEVELOPMENT OF THRUST CONTROL SYSTEM FOR LIINEAR SYNCHRONOUS MOTORS Ikeda, $\mathrm{H}_{\text {, }}$ and Kawaguchi, I.

Electr. Eng. Jpn, Vol. 108, No. 5, Sept.-Oct 1988, pp. 93-102

(NTIS No. 89-08 04191)

DIGITAL CONTROL OF ATTRACTIVE LEVITATION WITH PERMANENT MAGNET

Miyamoto, K.; Murai, T.; Koga, S.; Onuki, T.

Proc., 11th Int. Cont. Magnetically Levitated Syst. and Linear Drives, July 7-11, 1989, Yokohama, Japan, Publ. by IEE Jpn., pp. 447-452 
EI.ECTRO-MAGNETIC LEVITATION CONTROL OF AN ELASTIC PLATE

Oshinoya, Y., and Shimogo, Taro

Proc., 11th Int. Conf. Magnetically Levitated Syst. and Linear Drives, July 7-11, 1989, Yokohama, Japan, Publ. by IEE Jpn., pp. 435-440

REAL-TIME CONTROL OF A NONLINEAR MAGLEV SYSTEM USING CONCURRENT PROCESSING TECHINIQUES

Sinha, P. K.

Proc., 11th Int. Conf. Magnetically Levitated Syst. and Linear Drives, July 7-11, 1989, Yokohama, Japan, Publ. by IEE Jpn., pp. 417-422

FLEXIBLE STRUCTURE CONTROL. OF MAGLEV VEHICLES BY ACTIVE SECONDARY SUSPENSIONS Nagai, M., and Sawada, Y.

Proc., 11 th Int. Conf. Magnetically Levitated Syst. and Linear Drives, July 7-11, 1989, Yokohama, Japan, Publ. by IEE Jpn., pp. 393-398

SIGNAL AND COMMUNICATION SYSTEM OF HSST-05

Hashimoto, $F$.

Proc., 11th Int. Conf. Magnetically Levitated Syst. and Linear Drives, July 7-11, 1989, Yokohama, Japan, Publ. by IEE Jpn., pp. 303-308

HIGHLY RELIABLE CONTROL AND PROTECTION FOR THE TRANSRAPID HIGH SPEED MAGLEV TRANSPORTATION SYSTEM

Bimmermann, $H_{\text {.: }}$ Geduhn, N.; Knigge, R.; and Schnieder, E.

Proc., 11 th Int. C. nf. Magnetically Levitated Syst. and Linear Drives, July 7-11, 1989, Yokohama, Japan, Publ. by IEE Jpn., pp. 297-301

TRAIN CONTROLS AND FEEDING SYSTEMS FOR MAGNETICALLY LEVITATED SYSTEMS

Hirao, $Y_{\text {, }}$ and Sasaki, $T$.

Proc., 11 th Int. Conf. Magnetically Levitated Syst. and Linear Drives, July 7-11, 1989, Yokohama, Japan, Publ. by IEE Jpn., pp. 291-296

A MAGNETIC SUSPENSION SYSTEM OF LINEAR INDUCTION MOTOR - CONTROL METHOD AND STABILITY OF SUSPENDED MOTION

Hikihara, T.; Hirata, T.; Hirane, Y.

Proc., 11 th Int. Conf. Magnetically Levitated Syst. and Linear Drives, July 7-11, 1989, Yokohama, Japan, Publ. by IEE Jpn., pp. 203-208

LSM CONTROL METHOD FOR MULTIPLE POWER CONVERSION STATIONS Ikeda, H.; Kawaguchi, I.; Fujie, J.

Proc., 11th Int. Conf. Magnetically Levitated Syst. and Linear Drives, July 7-11, 1989, Yokohama, Japan, Pub. by IEE Jpn., pp. 141-146 


\section{Guideway Designs}

FLAT GUIDANCE SCHEMES FOR MAGNETICALLYY LEVITATED HIGH-SPEED GUIDED GROUND TRANSPORT

Atherton, D. L., and Eastham, A. R.

J. Appl. Phys., Vol. 45, 1974, pp. 1398-1405

TRANSVERSE EDGE EFFECTS OF SHEET GUIDEWAYS IN MAGNETIC LEVITATION

Doi, B. T., and Eastham, A. R.

IEEE Trans. Power Appar. Syst., Vol. PAS-94, 1975, pp. 72-80

DESIGN OF FLAT LADDER AND COIL GUIDEWAY SYSTEMS FOR HIGH SPEED TRAINS

Burke, P. E., and Akinbiyi, T.

IEEE Traris. Magn., Vol. MAG-12, No. 6, Nov. 1976, pp. 882-884

(NTIS No. 77-08 08139)

COMPARISON OF LADDER AND SHEET GUIDEWAYS FOR ELECTROMAGNETIC LEVITATION OF HIGH SPEED VEHICLES

Akinbiyi, T., and Burke, P. E.

IEEE Trans. Magn., Vol. MAG-12, No. 6, Nov. 1976, pp. 879-881

(NTIS No. 77.08 08138)

FORCES ON MAGNETICALLY LEVITATED VEHICLES ABOVE FLAT GUIDEWAYS - A MODELLING TECHNIQUE

Campbell, P., and Johnson, R. B.I.

IEE Conf. Publ. (London) No. 142, 2nd Conf. on Adv. Magn. Mater. and Their Appl., London, England, Sept. 1-3, 1976, pp 128-130

(NTIS No. 77-09 01378) (Theoretical analysis with some test results obtained from a small rotating disc)

FORCE TRANSIENTS AT GUIDEWAY BUTT JOINTS IN REPULSIVE MAGNETIC LEVITATION SYSTEM Doi, B. T., and Jain, O. P.

IEEE Trans. Power Appar. Syst., Vol. PAS-98, No. 1, Jan.-Feb. 1979, pp. $323-332$

(NTIS No. 79-06 00452)

STRUCTURES ON EXPERIMENTAL. LINE OF JNR'S MAGNETIC LEVITATION SYSTEM

Niwa, $T$., and Kuwahara, $Y$.

Civ. Eng. Jpn., Vol. 17, 1978, pp. 47-69

(NTIS No. 79-08 05038)

TOLERANCE OF GUIDEWAY IRREGULARITY AND ITS CONTROL ON THE MIYAZAKI TEST TRACK

Sato, Y.; Kishimoto, S.; Miura, S; Takeshita, K.

Q. Rep. Railw. Tech. Res. Inst. (Jpn), Vol. 21, No. 1, March 1980, pp. 1-8

(NTIS No. 81.01 07197)

DESIGN STUDY OF THE GUIDEWAY FOR THE CANADIAN HIGH SPEED MAGNETICALLY LEVITATED

VEHICLE SYSTEM

Atherton, D. L.; Campbell, T. I.; Eastham, A. R.; Fitzpatrick, C.; Hayes, W. F.; Van Dalen, K.

J. Adv. Transp., Vol. 16, No. 1, Spring 1982, pp. 25-58

(NTIS No. 82-10 06293)

IMPLEMENTATION OF A MAGLEV VEHICLE SUSPENSION FOR FLEXIBLE GUIDEWAYS

Lawton, A. P.

Veh. Syst. Dyn., Vol. 14, No. 1-3, June 1985, pp. 144-149

(NTIS No. 86-03 08789) 
RUNNING TRACK OF THE LINEAR MOTOR CAR

Nishiki, T.; Akihama, Y.; Sakaguchi, T.; Ninagawa, Y.; Yamamiya, M.; Terada, M.

Proc., Int. Conf. Maglev Transport '85, Sept. 17-19, 1985, Keidanren Kaikan, Tokyo, Japan, Publ. by IEE, Japan, pp. 319-324

(Test results)

DEVELOPMENT OF GUIDEWAY FOR MAGLEV

Sato, $Y$., and Matsuura, A.

Proc., Int. Conf. Maglev Transport '85, Supt. 17-19, 1985, Keidanren Kaikan, Tokyo, Japan, Publ. by IEE, Japan, pp. 243-250

(Review based on operational experience)

BIRMINGHAM AIRPORT MAGLEV-THE DEVELOPMENT AND DESIGN OF THE SUPPORT STRUCTURE AND GUIDEWAY

North, B. H.

Proc., Int. Conf. Maglev Transport '85, Sept. 17-19, 1985, Keidanren Kaikan, Tokyo, Japan, Publ. by IEE, Japan, pp. 237-242

(Design and development)

STEEL GUIDEWAYS FOR ELECTROMAGNETIC HIGH-SPEED TRANSPORTATION SYSTEMS

Raschbichler, H. G., and Schwindt, G.

Proc., Int. Conf. Maglev Transport ' 85 , Sept. 17-19, 1985, Keidanren Kaikan, Tokyo, Japan, Publ. by IEE, Japan, pp. 225-235

(System description and operational experience)

A RESPONSE-ELIMINATED DESIGN OF SIMPLY SUPPORTED BEAM FOR A GUIDEWAY OF A HIGH SPEED MAGLEV SYSTEM

Iguchi, M., and Hara, $H$.

Proc., Int. Conf. Maglev Transport '85, Sept. 17-19, 1985, Keidanren Kaikan, Tokyo, Japan, Publ. by IEE, Japan, pp. 217-224

(Theoretical analysis and design)

DYNAMIC CHARACTERISTICS OF MAGLEV VEHICLE MLU001 - GUIDEWAY IRREGULARITY TEST Yoshioka, $H$., and Miyamoto, $M$.

Proc., Int. Conf. Maglev and Linear Drives, May 14-16, 1986, Vancouver, B. C., Canada, Publ. by IEEE, 86CH2276-4, pp. 89-94

(Test Results)

GUIDEWAY FOR MAGLEV

Joyce, $H$.

Spaceflight, Vol. 28, No. 5, May 1986, pp. 205-206

(NTIS No. 86-11 02964)

A JACK SYSTEM WHICH RECTIFIES HSST TRACK BEAMS ON SINKING UNI-LOAD BASE FOUNDATION

Okada, K.; Kakurai, M.; Enokuchi, M.; Hoshino, H.; Iwaya, M.

Proc., 11 th int. Conf. Magnetically Levitated Syst. and Linear Drives, July 7-11, 1989, Yokohama, Japan, Publ. by IEE Japan, pp. 315-320 


\title{
10 Superconducting Magnets and Cryogenic Technologies
}

(Also see 4 Suspension and Levitation Techniques)

\author{
MAGNETIC SUSPENSION AND GUIDANCE FOR HIGH-SPEED ROCKETS BY SUPERCONDUCTING \\ MAGNETS \\ Guderjahn, C. A.; et al. \\ J. Appl. Phys., Vol.40, No.5, pp. 2133-2140, Presented at Applied Superconductivity Conf. and \\ Exhibition, Gatlinburg, Tenn., USA, Nov. 1969 \\ (Abstract) \\ SUSPENSION AND GUIDANCE OF VEHICLES BY SUPERCONDUCTING MAGNETS \\ Coffey, H. T.; Chilton, F.; Barbee, T. W. \\ J. Appl. Phys., Vol. 40, p. 2161, Presented at Applied Superconductivity Conf. and Exhibition, \\ Gatlinburg, Tenn., USA, Nov. 1969 \\ (Abstract)
}

THE ROLE OF SUPERCONDUCTING MAGNETS IN TRACKED MAGNETIC CUSHION VEHICLES FOR HIGH SPEED TRANSPORTATION

Reitz, J.R.

5th Int. Applied Superconductivity Conf., May 1-3, 1972, pp. 57-61, IEEE Pub. No. 72CH0682-5 TABSC

SUPERCONDUCTING MAGNET FOR "ML-100"

Saito, R.; Fujinaga, T.; Tada, N.; Kimura, H.

Hitachi Review, Vol. 24, No. 2, pp. 103-108

(TRIS No. 125820 DA)

\section{SUPERCONDUCTING MACHINES AND DEVICES}

Iwasa, $Y$.

High-Speed Magnetically Levitated and Propelled Mass Ground Transportation, Edited by S. Foner and

B. Schwartz, Plenum Press, New York and London, 1973, Chap. 6, pp 347-399

SOME APPLICATIONS OF CRYOGENICS TO HIGH SPEED TRANSPORTATION

Arp, V. D.; Clark, A. F.; Flynn, T. M.

Natl. Bureau of Standards, Cryogenics Div., Boulder, Colo., Feb. 1973, 31 pp.

(TRIS No. 242636 DA)

SUPERCONDUCTING LEVITATION OF HIGH SPEED VEHICLES

Arp, V. D.; Clark, A. F.; Flynn, T. M.

Transportation Engineering Journal, Vol. 99, No. TE4, Nov. 1973, pp. 873-875

(TRIS No. 054475 DA)

ON-BOARD CRYOGENIC SYSTEM FOR MAGLEV LEVITATION OF TRAINS: CRYOGENIC

SYSTEM OF EET

Asztalos, S. L.; Baldus, W.; Kneuer, R.; Stephan, A.

Proc. 5ih Int. Cryog. Eng. Conf., Kyoto, Japan, May 7-10, 1974, pp.37-41

(TRIS No. 130899 DA) (Test results)

SUPERCONDUCTIVITY: LARGE-SCALE APPLICATIONS

Science, Vol. 185, No. 4147, July 1974, pp. 211-222

(TRIS No. 260198 DA) (Introduction)

ON-BOARD CRYOGENIC SYSTEM FOR MAGLEV LEVITATION OF TRAINS: CRYOGENIC

SYSTEM OF EET

Asztalos, S. L.; Baldus, W.; Kneuer, R.; Stephan, A.

Cryogenics, Vol. 15, No. 2, Feb. 1975, pp. 52-56

(TRIS No. 096590 DA) 
DEVELOPMENT OF SUPERCONDUCTING MAGNETS FOR MAGNETICALLY SUSPENDED HIGHSPEED TRAINS

Ogiwara, H.; Takano, N.; Okamoto, H.; Hayashi, K.

Toshiba Review, Vol. N98, July 1975, pp. 7-11

(TRIS No. 130906 DA)

SUPERCONDUCTING MAGNETS (A BIBLIOGRAPHY WITH ABSTRACTS)

Reimberr, G. W.

Natl. Tech. Inf. Service, 5285 Port Royal Rd., Springfield, Va. 22161, Oct. 1976, 251 pp., 246 ref. (TRIS No. 146104 DA)

HIGH-SPEED TRANSPORTATION LEVITATED BY SUPERCONDUCTING MAGNET

Oshima, $\mathrm{K}$.

Advances in Cryogenic Engineering, Vol. 199, pp. 127-136

(TRIS No. 098008 DA)

SUPERCONDUCTING SOLENOIDS FOR SUSPENSION OF HIGH-SPEED MEANS OF SURFACE TRANSPORTATION

Omel' Yanenko, V. I.; Bocharov, V. I.: Dolgosheev, E. A.; Usichenko, Y. G.

Izvestiia Vysshikh Ucheb Zaved, Elekrromekhanika NB, Aug. 1977, pp. 875-878 (Russian)

(TRIS No. 177172 DA) (Review existing designs)

SUPERCONDUCTING MAGNETS FOR MAGNETIC LEVITATION: STATE OF DEVELOPMENT (1978) IN ERLANGEN

Albrecht, C.

Int. Seminar on Superconductive Magnetic Levitated Train, Miyazaki, Japan, Nov. 1978, pp. 74-84

(Status report)

REFRIGERATION TECHNOLOGY AND RELATED PROBLEMS

Oshima, $\mathrm{K}$.

Int. Seminar on Superconductive Magnetic Levitated Train, Miyazaki, Japan, Nov. 1978, pp. 70-73

(Summary)

SUPERCONDUCTING MAGNETS AND RELATED PROBLEMS

Ohtsuka, $T$.

Int. Seminar on Superconductive Magnetic Levitated Train, Miyazakl, Japan, Nov. 1978, pp. 67-69

(Introduction)

CRYOGENIC SYSTEM FOR ONBOARD SUPERCONDUCTIVE MAGNET

Nakashima, $\mathrm{H}$.

Q. Rep. Railw. Tech. Res. Inst. (Jpn), Vol. 20, No. 1, March 1979, pp. 1-8

(TRIS No. 196532 DA)

SUPERCONDUCTING MAGNETS. SEPTEMBER, 1978-SEPTEMBER, 1980 (CITATIONS FROM THE NTIS DATA BASE)

Reimherr, G. W.

Natl. Tech. Inf. Service, 5285 Port Royal Rd., Springfield, Va. 22161, Oct. 1980 (Bibliography containing 218 Citations).

(TRIS No. 327031 DA)

SHUNT PROTECTION FOR SUPERCONDUC TING MAGGLV MAGNETS

Atherton, D. L.

Cryogenics, Vol.19, No. 9, Sept. 1979, pp. 537-541

(80-01 01204) 
COOLING CHARACTERISTICS OF SUPERCONDUCTING MAGNET COOLED WITH THE HELIUM REFREGERATOR

Nakashima, $H_{\text {., }}$ and Herai, T.

Q. Rep. Railw. Tech. Res. Inst. (Jpn), Vol . 21, No. 1, March 1980, pp. 35-39

(TRIS No. 323195 DA)

\section{SUPERCONDUCTING MAGNETS - REFLECTIONS ON STABILITY VS PROTECTION}

Iwasa, $Y$.

The Second Int. Seminar on Superconductive Magnetic Levitated Train, Miyazaki, Japan, Nov. 1982, pp. 106-110 (Theoretical analysis)

\section{CANADIAN MAGLEV CAYOGENIC SYSTEM DEVELOPMENT}

Fife, A. A.

The Second Int. Seminar on Superconductive Magnetic Levitated Train, Miyazakl, Japan, Nov. 1982, pp. 102-105 (Introduction)

\section{ON-BOARD REFRIGERATOR}

Mita, $H$.

The Second Int. Seminar on Superconductive Magnetic Levitated Train, Miyazaki, Japan, Nov. 1982, pp. $78-91$ (Japanese)

\section{ON-BOARD REFRIGERATOR}

Terasaki, $M$.

The Second Int. Seminar on Superconductive Magnetic Levitated Train, Mlyazaki, Japan, Nov. 1982, pp. 65-71 (Japanese)

\section{CRYOSTAT FOR MAGNETIC LEVITATED TRAIN}

Funuta, $Y$.

The Second Int. Seminar on Superconductive Magnetic Levitated Train, Miyazaki, Japan, Nov. 1982, pp. $57-64$

\section{MAGLEV SUPERCONDUCTING COIL}

Yamaji, $M$.

The Second Int. Seminar on Superconductive Magnetic Levitated Train, Miyazaki, Japan, Nov. 1982, pp. $49-56$

\section{MAGLEV SUPERCONDUCTING MAGNET SYSTEM}

Fujinaga, $T$.

The Second Int. Seminar on Superconductive Magnetic Levitated Train, Miyazaki, Japan, Nov. 1982, pp. $38-48$

\section{COMPOSITE SUPERCONDUCTORS}

Chawla

Morgan-Grampian Limited

Engineer, Vol. 224, No. 1, Jan. 1984, pp. 39-41

(TRIS No. 382632 DA)

\section{ON-BOARD REFRIGERATION SYSTEM OF MAGNETICALLY LEVITATED HIGH SPEED}

TRAINS MLUOO1

Ohguma, H.; Wada, T.; Yamail, H.; Nakao, A.; Nakashima, $H$.

Proc., Int. Cont. Maglev Transport '85, Sept. 17-19, 1985, Keidanren Kaikan, Tokyo, Japan, Publ. by IEE, Japan, pp. 193-198 (Design and exp. results)

EFFICIENCY OF PASSIVE MAGNETIC-CONFINEMENT METHODS FOR RAPIDLY ROTATING SOLID RINGS

Hull, J.R.

J. Appl. Phy., Vol. 58, 1985, pp. 3594-3600 
SUPERCONDUCTING MAGNET FOR MAGLEV TRAIN

Jizo, $Y_{\text {.; }}$ Funuta, $Y_{\text {.; }}$ Nakashima, $H_{\text {.; }} T$. Iwahana

Proc., Int. Cont. Maglev Transport '85, Sept. 17-19, 1985, Keldanren Kaikun, Tokyo, Japan, Publ, by IEE, Japan, pp. 185-192, (Area review)

RESEARCH AND DEVELOPMENT OF SUPERCONDUCTING COILS FOR MAGLEV CARS Iwaharla, T, and Nemoto, $K$.

Q. Rep. Railw. Tech. Res. Inst. (Jpn), Vol. 26, No. 3, Sept. 1985, pp. 103-109

(NTIS No. 86-05 04441)

DEVELOPMENT OF HIGH ELECTRICAL. RESISTANCE PERSISTENT CURRENT SWITCH FOR HIGH SPEED ENERGIZATION SYSTEM

Jizo, Y., and Furuta, $Y$.

Proc., Int. Conf. Maglev and Linear Drives, May 14-16, 1986, Vancouver, B. C., Canada, Publ. by IEEE, $86 \mathrm{CH} 2276.4$, pp. 219-225

(Theoretical analysis and sample test results)

DEVELOPMENT OF SUPERCONDUCTOR MAGNETS FOR THE CANADIAN ELECTRODYNAMIC MAGLEV VEHICLE

Fife, A. A.; Ensing, H. J.; Tillotson, M.; Westera, W.

Proc., Int. Conf. Maglev and Linear Drives, May 14-16, 1986, Vancouver, B. C., Canada, Publ, by IEEE, $86 \mathrm{CH} 2276-4$, pp. $211-217$

(Review, discussion, and experiment)

DEVELOPMENT OF SUPERCONDUCTING COILS FOR MAGLEV

Iwahana, T., and Nemoto, K.

J. Japan. Society of Mechanical Engineers, Vol. 89, No. 817, Dec. 1986, pp 1353.59

(TRIS No. 468441)

ANALYSIS OF SHIELDING AGAINST MAGNETIC FLUX DENSITY MAKING USE OF

SUPERCONDUCTING MATERIAL

Terauch, $N$.

Q. Rep. Railw. Tech. Res. Inst. (Jpn), Vol. 29, No. 4, Nov. 1988, pp. 164-171

(NTIS No. 89-04 0'2125)

ADVANTAGES OF HIGH-TEMPERATURE SUPERCONDUCTIVITY IN LARGE-SCALE APPLICATIONS Hull, J. R.

Proc., Arnerican Soclety of Mechanical Eng. 109th Winter Annual Meeting, Chicago, Nov. 28-Dec.2, 1988

THE CAYOGENIC SYSTEM FOR MAGNETIC LEVITATION VEHICLES

Nakashima, $H$., and Heral, $T$.

Proc., 11 th Int. Cont. Magnetically Levitated Syst. and Linear Drives, July 7-11, 1989, Yokohama, Japan, Publ. by IEE Jpn., pp. 235-239

NEW TYPE SUPERCONDUCTING MAGNET FOR EDS SYSTEM

Nakao, H.; Yamaji, M.; Kurosawa, K.; Jizo, Y.; Nakashima, H.; Tsuchishima, $H$.

Proc., 11 th Int. Conf. Magnetically Levitated Syst. and Linear Drives, July 7-11, 1989, Yokohama, Japan, Publ. by IEEE Jpn., pp. 229-234 


\section{Power Supply Systems}

REACTIVE POWER COMPENSATED CYCLOCONVERTER

Shimada, K.; Ikeda, H.; Saljo, T.

Q. Rep. Railw. Tech. Res. Inst. (Jpn), Vol, 25, No.1, 1984, pp. 33-38

(NTIS No. 84-09 07683)

DRIVE AND ENERGY SUPPLY SYSTEMS FOR MAGNETIC LEVITATION LINES

Drelmann, $K_{1}$, and Clessow, $G$.

Elektr. Bahnen, Vol. 82, No. 3, March 1984, pp. 82-86

(NTIS No. 85-10 00589)

POWEA SUPPLY SYSTEM TO DRIVE MAGLEV VEHICLES MLU 001

Ikeda, $H_{\text {., and Iwawakl, S. }}$

Q. Rep. Railw. Tech. Res. Inst. (Jpn), Vol. 27, No. 1, March 1986, pp. 26-31

(NTIS No. 86-07 10446)

POWER SUPPLY SYSTEM TO DRIVE MAGLEV VEHICLES MLU 001

Ikeda, H.; Iwawaki, S.; Nakamichi, Y.; Outake, T.; Saijo, T.

Proc., Int. Cont. Maglev Transport '85, Sept. 17-19, 1985, Keldanren Kaikan, Tokyo, Japan, Publ. by IEE, Japan, pp. 99-106

(Construction and characteristics of the cycloconverter with control scheme)

LSM PROPULSION SYSTEM OF THE MIYAZAKI MAGLEV TEST TRACK

Nakamura, N.; Koike, S.; Tatsurni, T.; Maki, N., Nakamichl, Y.; Nishl, N.

Proc., Int. Cont. Maglev Transport '85, Sept. 17-19, 1985, Keidanren Kalkan, Tokyo, Japan, Publ. by IEE, Japan, pp. 91-98

(Control and drive system for EML)

PROPUL.SION AND POWER SUPFLY SYSTEM OF THE TRANSRAPID O6 VEHICLE DESIGN AND

TEST RESULTS- PAAT 2: POWER SUPPLY

Dreimann, K.; Friedrich, R.; Lelstikow, R.; Clebow, G.; Grunwald, H.; Wienenga, P.

Proc., Int. Cont. Maglev Transport '85, Sopt. 17-19, 1985, Keldanren Kalkan, Tokyo, Japan, Publ. by IEE, Japan, pp. 83-90

(General discussion on design and test results)

THE STATE-OF-THE-ART TECHNOLOGY OF ON-BOARD INVERTERS FOR TRACTION

Sone, S.

Proc., Int. Cont. Maglev Transport '85, Sept. 17-19, 1985, Keidanren Kaikan, Tokyo, Japan, Publ. by IEE, Japan, pp. 69-74

(Discussion on power electronics technology)

DEVELOOPMENT OF HIGH ELECTRICAL RESISTANCE PERSISTENT CURRENT SWITCH FOR HIGH

SPEED ENERGIZATION SYSTEM

Jizo, $Y$, and Furuta, $Y$.

Proc., Int. Conf. Maglev and Linear Drives, May 14-16, 1986, Vancouver, B. C., Canada, Publ. by IEEE, 86CH2276-4, pp. 219-225

(Theoretical analysis and sample test)

POWER SUPPLY SYSTEM TO DRIVE HSST-EXPO ' 86

Suzuki, S.; Hikasa, Y.; Suzukl, K.; Hosoda, Y.; Yamaoka, S.; Takada, N.

Proc., Int. Conf. Maglev and Linear Drives, May 14-16, 1986, Vancouver, B. C., Canada, Publ. by IEEE, 86CH2276-4, pp. 69-88

(Summary and discussion) 
THE POWER SUPPLY AND THE PROPULSION SYSTEM OF THE TRANSRAPID 06 VEHIOLE RESULTS OF TRIALS

Friedrich, R.; Drelmann, K.; Leistlkow, $P$.

Proc., Int. Cont. Maglev and Linear Drives, May 14-16, 1986, Vancouver, B. C., Canada, Publ. by IEEE, $86 \mathrm{CH} 2276-4$, pp. $251-256$

(Status report, operational results)

CHOOSING A PROSPECTIVE DRIVE FOR TRANSPORTATION VEHICLES WITH MAGNETIC

SUSPENSION AND LINEAH TRACTION MOTORS

Bocharov, V. I., and Suslova, K. N.

Sov. Electr. Eng., Vol. 58, 1987, pp. 99-10?

(NTIS No. 88-05 04296)

ZERO POWER CONTROL. OF ELECTROMAGNETIC LEVITATION SYSTEM

Morishita, M., and Azukizawa, T.

Electr. Eng. Jpn., Vol. 108, No. 3, May-June 1988, pp. 111-120

(NTIS No. 89-03 02282)

RATE OF ELECTRIC POWER CONSUMPTION AND INSTALLED ELECTRIC POWER CAPACITY AT SUBSTATION WITH ON-BOARD PRIMARY LINEAR INDUCTION-DRIVEN RAILWAY

Mizuma, T, and Matsumoto, A.

Proc., 1 ith Int. Conf. Magnetically Levitated Syst, and Linear Drives, July 7-11, 1989, Yokohama, Japan, Publ. by IEE Jpn., pp. 309-313

LEVITATION MAGNET DRIVER FOR HSST - CONTROLLED BY SI THYYRISTORS

Nagata, K.; Sekimoto, $H_{\text {; }}$ Mural, $M$.

Proc., 11 th Int. Cont. Magnetically Levitated Syst. and Linear Drives, July 7-11, 1989, Yokohama, Japan, Publ. by IEE Jpn., pp. 257-262

AUXILIARY POWER SYSTEM FOR HSST-05

Takel, $H_{\text {., and Suzukl, } K \text {. }}$

Proc., 11 th Int. Cont. Magnetically Levitated Syst. and Linear Drives, July 7-11, 1989, Yokohama, Japan, Publ. by IEE Jpn., pp. 191-196

NEW MODULATION METHOD FOR VVVF INVERTER FOR HSST-05

Mlyashita, l., and Ohmorl, Y.

Proc., 11 th Int. Conf. Magnetically Levitated Syst, and L.Inear Drives, July 7-11, 1989, Yokohama, Japan, Publ. by IEE Jpn., pp. 185-190

A NEW CONTROL. METHOD FOR FORCED COMMUTATED PWM CYCLOCONVERTERS USING A MICROPROCESSOR

Furuhashi, T.; Ishiguro, A.; Ishida, M.

Proc., 11th Int. Cont. Magnetically Levitated Syst. and Linear Drives, July 7-11, 1989, Yokohama, Japan, Publ. by IEE Jpr., pp. 173-178

HARMONIC RESONANCE APPEARING IN INPUT SIDE OF BIG POWER CONVERTER FOR DRIVING LSM

Kawaji, M.; Saljo, T.; Ikeda, H.; Kaga, S.

Proc., 11 th Int. Cont. Magnetically Levitated Syst, and Linear Drives, July 7-11, 1989, Yokohama, Japan, Publ, by IEE Jpn., pp. 167-172

OPTIMIZING THE FEEDING SYSTEM FOR LINEAR SYNCHRONOUS MOTOR OF EDS JAPAN Ishizu, S.

Proc., 11th Int. Cont. Magnetically Levitated Syst, and Linear Drives, July 7.11, 1989, Yokohama, Japan, Publ. by IEE Jpn., pp. 161-166 
A STUDY ON THE POWER SUPPLY NETWOAK FOH A SUPEASPEED MAGLEV TRANSPOAT Masada, E; Ohsakl, H.i Tamura, M.i Torli, S.

Proc., 11 th int. Cont. Magnetlcally Levitated Syst, and L..near Drives, July 7-11, 1989, Yokohama, Japan, Publ. by IEE Jpn., pp. 155-160

\section{ELECTRIC EQUUIPMENT OF THE CHIJO LINEAR EXPRESS}

Sokl, $A_{1}$, and Simomae, T.

Proo., 1tth Int. Cont. Magnetloally Levitated Syst, and Linear Drlves, July 7-11, 1989, Yokohama, Japan, Publ. by IEE Jpn., pp. 135-139 


\section{Numerlcal Analysis}

THAEE-DIMENSIONAL EDDY CUARENT ANALYSIS OF CRYOSTAT OUTER.VESSEL IN SUPERCONDUCTIVE MAGNETICALLYY LEVITATED VEHICLE

Nonaka, S.; Sakamolo, T.; Ueno, T.

Proc., Int. Cont. Maglev and Linear Drives, Las Vegas, Nev., USA, May 19-21, 1987, Publ, by IEEE, 87CH2443-0, pp. 67-72

THREE DIMENSIONAL SOLUTION OF HIGH.SPEEU MAGNETIC LEVITATION PROBLEMS

Nicolas, A.; Sabonradlere, J. C.i Slivester, P. P.

J. Appl. Phys, Vol, 53, No, 11, Pl, 2, Nov, 1982, pp. 8417-8419

(NTIS No. 83-05 02762)

FINITE ELEMENT MODELS OF EXTERIOR REGIONS CONTAINING MOVING CONDUCTORS Lowther, D. A, and Sllvester, P.P.

COMPUMAG Conf, on the Comput. of Magn. Fleld, Commun. Proo., Grenoble, France, Sept, 4-6, 1978, Publ, by Lab. d'Electrotech., Grenoble, France, 1978, Pap. 3, 4, 6pp., Location of Work - Imp. Coll of Soc. \& Technol, Loridon, England

(NTIS No. 80.03 04678)

A 3-DIMENSIONAL CALCULATION METHOD FOR A LIM HAVING U-SHAPED SECONDAAY COMPARED WITH MEASUREMENTS

Sattler, P. K.

Proc., Int. Cont. Maglev Transport '85, Sept, 17-19, 1985, Keldanren Kalkan, Tokyo, Japan, Publ. by IEE, Japan, pp. 29.36

(Numerical and test results)

BOUNDARY ELEMENT ANALYSIS OF LINEAR INDUCTION MOTOR FOR MAGLEV VEHICLE

Nonaka, $S_{1}$ and Ogawa, K.

Proc., Int. Conf, Maglev and Linear Drlves, May 14-16, 1986, Vancouver, B. C., Canada, Publ. by IEEE, $86 \mathrm{CH} 2276-4$, pp. $171-177$

(Numerical Fresults)

FINITE ELEMENT ANALYSIS OF LINEAR INDUCTION MOTORS TAKING INTO ACCOUNT DISCONTINUITY OF SECONDARY RAILS

Nonaka, S., and Furukawa, T.

Proc., 1 1 th Int. Cont. Magnetlcally Levitated Syst, and Linear Drlves, July 7-11, 1989, Yokohama, Japan, Publ. by

IEE Jpn., pp. $339-344$

COMPUTATION OF MAGNETIC SUSPENSION OF MAGLEV SYSTEMS USING DYNAMIC CIRCUIT

THEOAY

He, J.L.; Rote, D.M.; Coffey, H.T.

Internationál Symposium on Magnetlo Suspension Technology, NASA Langley Research Center,

Hampton, Va., USA, Aug. 19-23, 1991

PRESENT STATUS OF COMPUTATIONAL TOOLS FOR MAGLEV DEVELOPMENT

Wang, Z.; Chan, S.; Rote, D.

Report No. ANL./ESD/TM-24, Center for Transportation Research, Energy Systems Division, Argonne

Natlonal Laboratory, Dec. 1991 


\section{Safety Considerations}

SAFETY ASPECTS OF THE MAGLEV TEST SITE TRANSRAPID VERSUCHSANLAGE EMSLAND Jansen, $H$. and Mnich, $P$.

Proc., Int. Conf. Maglev Transport '85, Sept. 17-19, 1985, Keidanren Kaikan, Tokyo, Japan, Publ. by 'EE, Japan, pp. 295-302

(Theoretical discussions)

SAFETY AND LICENSING ASPECTS OF TRANSRAPID AND MAGLEV SYSTEM

Blomerius, D. I. J.

Proc., Int. Conf. Maylev and Linear Drives, Las Vegas, Nev., USA, May 19-21, 1987, Publ. by IEEE,

87CH2443-0, pp. 205-210

(Introduction and state report)

CONCEPT OF THE OPERATIONAL SAFETY SYSTEM FOR THE CHUO LINEA. 7 EXPRESS

Seki, A.; Kato, S.; Kawakami, T.

Proc., 11 th Int. Conf. Magnetically Levitated Syst. and Linear Drives, July 7-11, 1989, Yokohama, Japan, Publ. by IEE Jpn., pp. 287-290

DEVELOPMENT OF AERODYNAMIC BRAKE OF MAGLEV VEHICLE FOR EMERGENCY USE

Oda, K.; Azakami, M.; Yoshimura, M.

Proc., 11 th Int. Conf. Magnletically Levitated Syst. and Linear Drives, July 7-11, 1989, Yokohama, Japan, Publ. by IEE Jpn., pp. 281-286

SAFETY REQUIREMENTS FOR MAGLEVS IN GERMANY - VIEW AND FORECAST

Jansen, Ing. $H$.

Proc., 11th Int. Cont. Magnetically Levitated Syst. and Linear Drives, July 7-11, 1989, Yokohama, Japan, Publ. by IEE Jpn., pp. 73-79 


\section{Electromagnetic Field Shielding}

MAGNETIC SHIELDING FOR MAGNETICALLLY LEVITATED VEHICLES

Wwasa, $Y$.

IEEE Proc., Vol. 61, No. 5, May 1973

(TRIS No. 046397 DA)

AN APPRAISAL OF LIMIT OF SAFE EXPOSURE TO MAGNETISM

Nakagawa, $M$.

The Second int. Serninar on Superconductive Magnetic Levitated Train, Miyazaki, Japan, Nov. 1982, pp. $111-116$

(Experimental analysis)

ENVIROMENTAL ASSESSMENT FOR A SUPER-SPEED GROUND TRANSPORTATION SYSTEM PROPOSED TO LINK LAS VEGAS TO SOUTHERN CALIFORNIA

Flowers, C. A.

Proc., Int. Conf. Maglev and Linear Drives, Las Vegas, Nev., USA, May 19-21, 1987, Publ. by IEEE, 87CH2443-0, pp. 241-245

(Feasibility Studies)

MAGNETIC FIELD SHIELDING FOR ELECTRODYNAMIC MAGLEV VEHICLES

Hayes, W. F.

Proc., Int. Cont. Maglev and Linear Drives, Las Vegas, Nev., USA, May 19-21, 1987, Publ. by IEEE, 87CH2443-0, pp. 53-66

(Numerical Results) 


\section{Bibllography}

1. INTERNATIONAL SEMINAR ON SUPERCONDUCTIVE MAGNETIC LEVITATED TRAIN, Mlyazaki, Japan, November 9-10, 1978.

2. THE SECOND INTERNATIONAL SEMINAR ON SUPERCONDUCTIVE MAGNETIC LEVITATED TRAIN, Miyazaki, Japan, November 4-5, 1982.

3. INTERNATIONAL CONFERENCE ON MAGLEV TRANSPOHT'85, Tokyo, Japan, September 17-19, 1985. Published by IEE Japan.

4. INTERNATIONAL CONFERENCE ON MAGLEV AND LINEAR DRIVES, Vancouver, British Columbia, Canada, May 14-16, 1986, Published by IEEE, No. 86CH2.276-4.

5. INTERNATIONAL CONFERENCE ON MAGLEV AND LINEAR DRIVES, Las Vegas, Nevada, USA, May 19-21, 1987, Published by IEEE, No. 87CH2443-0.

6. 11TH INTERNATIONAL CONFERENCE ON MAGNETICALLY LEVITATED SYSTEMS AND LINEAR DRIVES, MAGLEV'89, Yokohama, Japan, July 7-11, 1989, Published by IEE Japan.

7. MAGLEV AND SUPERCONDUCTIVITY. Search of Transportation Research Information Service (TAIS) Database for Citations on Magnetic Levitation and Superconductivity by Barbara Post, Jariuary 19, 1989.

8. MAGNETIC LEVITATION FOR RAIL TAANSPORTATION (JAN. 1971-NOV. 1989). Citations from the COMPENDEX Database, National Technical Information Service (NTIS). 
15.2 


\section{Appendix A: \\ Some Sources of Useful Information}

NTIS:

U.S. Department of Commerce

National Technical Information Service

5285 Port Royal Road

Springfield, VA 22161

Subscription orders (703) 487-4630

To place an orrer $\quad$ (703) 487-4650

Rush orders 1-800-553-NTIS

Fax (703) 321-8547

Telex $\quad 89-9405$ or 64617

TRIS:

Transportation Research Information Service

Transportation Research Board

2101 Constitution Avenue, N.W.

Washington, DC 20418

Telephone (202) 334-3250

Telex 248664 NASWUR

Cable NARECO

IEEE:

Institute of Electrical and Electronic Engineers

Publishing Services

345 East 47th Street

New York, NY10017

IEE of Japan:

Institute of Electrical Engineers of Japan

1-12-1, Yurakucho, Chiyoda-ku

Tokyo, 100 Japan

NMI: Office of National Maglev Initiative

400 Seventh St., S.W.

Washington, DC 20590

Telephone (202) 366-6708

(202) 366-6144 
Japan Information Center of Science and Technology, Washington Office 1550 M Street, N.W.

Washington, DC 20005

Telephone (202) 872-6371

Fax (202) 872-6372 


\section{Appendix B:}

Author Index

$\begin{array}{llll}\text { Abe, M. } & 4.6 & \text { Audette, M. } & 2.3 \\ \text { Abel, E. } & 2.2,5.1 & \text { Audette, M. A. } & 3.8 \\ \text { Adamiak, K } & 5.6 & \text { Autruffe, H. } & 1.1 \\ \text { Aizawa, H. } & 3.5 & \text { Azakami, M. } & 13.1 \\ \text { Ajiki, K. } & 6.3 & \text { Azukizawa, T. } & 1.3,4.6,5.3,6.3, \\ \text { Akihama, Y. } & 9.2 & & 8.3,11.2 \\ \text { Akinbiyi, T. } & 9.1 & \text { Baertz, U. } & 5.2 \\ \text { Albrecht, C. } & 3.2,10.1 & \text { Bagryantsev, V. I. } & 7.4 \\ \text { Alexy, R. } & 1.3 & \text { Baibakov, S. N. } & 7.3 \\ \text { Alscher, H. } & 2.3,3.9,7.7 & \text { Baiko, A. V. } & 7.3 \\ \text { Alston, I. A. } & 4.1 & \text { Bakhvalov, Y. A. } & 6.3 \\ \text { Amano, H. } & 4.5 & \text { Balchin, M. J. } & 5.6 \\ \text { Amemiya, Y. } & 7.1 & \text { Baldus, W. } & 9.2 \\ \text { Ananthasivam, K. } & 5.4 & \text { Ballantyne, W.J. } & 5.5 \\ \text { Ando, M. } & 3.7 & \text { Barbee, T. W. } & 2.1,4.1,9.2 \\ \text { Andresen, E. } & 5.2 & \text { Barber, J. B. } & 1.2 \\ \text { Andrus, G. M. } & 2.3 & \text { Barlow, D. } & 5.6 \\ \text { Armstong, D. S. } & 4.4 & \text { Barwell, F. T. } & 3.10 \\ \text { Arp, V. D. } & 10.1 & \text { Basic, J. J. } & 6.3 \\ \text { Asakawa, Y. } & 5.7 & \text { Belanger, P. R. } & 3.4,3.5,4.2, \\ \text { Asher, G. M. } & 4.4,7.4 & \text { Bevir, M. K. } & 4.2 \\ \text { Asztalos, S. L. } & 10.1 & \text { Bimmermann, H. } & 8.4 \\ \text { Atherton, D. A. } & 6.2 & 3.1,3.2,3.3,3.4, & 3.6 \\ \text { Atherton, D. L. } & 7.1,9.1,10.1 & & 13.1 \\ & & & \end{array}$




\begin{tabular}{|c|c|c|c|}
\hline Bocharov, V. I. & $6.3,9.2,11.2$ & Ciebow, G. & 11.1 \\
\hline Boening, $B$. & 5.2 & Ciessow, G. & 11.1 \\
\hline Bohm, E. & 5.4 & Clark, A. F, & 9.2 \\
\hline Bohn, G. & $3.7,3.9,4.2,4.5$ & Clark, J. M. & 4.1 \\
\hline Bohn, G. H. & 6.2 & Clark, T. B. & 6.1 \\
\hline Boldea, $\mathrm{I}$. & $2.3,3.7,3.11$ & Coffey, H. T. & $\begin{array}{l}1.1,1.4,2.1,2.2, \\
2.4,3.1,4.1,7.1\end{array}$ \\
\hline Bondada, A. & 1.1 & & $10.1,12.1$ \\
\hline Boon, C. J. & $1.1,1.3$ & Coles, P. C. & 5.6 \\
\hline Burchert, J. & $3.5,3.6$ & Colton, D.J. & 3.1 \\
\hline \multirow[t]{2}{*}{ Borcherts, R. H. } & \multirow{2}{*}{$\begin{array}{l}1.1,2.2,3.1,3.2, \\
4.1,4.2,6.1,6.2, \\
7.1,7.4\end{array}$} & Cortes-Comerer, $\mathrm{N}$. & 1.3 \\
\hline & & Cunningham, J. A. & 5.1 \\
\hline Brand, N. M. & 1.2 & Cusack, P.M. & 5.6 \\
\hline Brdicko, J. & 5.5 & Daley, J. G. & 1.4 \\
\hline Breinl, W. & 8.2 & Dalgleish, E. H. & 3.9 \\
\hline Brock, K. H. & 8.1 & Danby, G. T. & $2.1,4.1,6.1$ \\
\hline Brown, J. & 4.4 & Daniels, E. & 1.4 \\
\hline Burke, P. E. & $3.4,5.2,9.1$ & Daris, L. C. & $\begin{array}{l}1.1,4.1,4.2,6.1, \\
6.2\end{array}$ \\
\hline Campbell, P. & 9.1 & Dawson G E & 135455,62 \\
\hline Campbell, T. I. & 1.3 & Deleroi W & \\
\hline Chahal, J. S. & 5.2 & & 0.1 \\
\hline Chawla & 10.1 & Dewan, S. B. & 5.1 \\
\hline Chen, S. & 12.1 & Dickhart, W. W. & 3.10 \\
\hline Cherchas, D. B. & 7.2 & Dogg, D. & 3.8 \\
\hline Chilton, $\mathrm{F}$. & $1.1,2.1,4.1$ & Doi, $\mathrm{T}$. & 1.4 \\
\hline Chong, $\mathrm{M}$. & 4.2 & Dolgosheev, E. A. & 10.1 \\
\hline Choudhury, C. P. & 5.6 & Dondiego, R. L. & 1.1 \\
\hline Chu, D. & 7.4 & Dreimann, K. & $\begin{array}{l}3.10,3.11,5.4 \text {, } \\
5.6,11.1\end{array}$ \\
\hline
\end{tabular}




\begin{tabular}{|c|c|c|c|}
\hline Duffek, W. & 8.2 & Fuhiwara, S & 4.6 \\
\hline Dunford, W. G. & 5.5 & Fujle, J. & $3.1,3.12,8.4$ \\
\hline \multirow[t]{3}{*}{ Eastham, A. R. } & $1.1,1.3,3.1,3.2$, & Fujli, H. & 3.6 \\
\hline & $\begin{array}{l}4.2,4.3,4.6,5.1 \\
5.4,5.5,6.2\end{array}$ & Fujli, N. & $5.5,5.6,7.6$ \\
\hline & 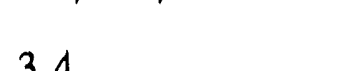 & Fujimoto, T. & $4.3,4.6$ \\
\hline Fastham I F & 4456 & Fujinaga, $T$. & $9.2,10.1$ \\
\hline Fastham $T R$ & 1453 & Fujisaki, K. & $5.4,7.4,7.5$ \\
\hline Lastican, 1.2 & $1.4,5.5$ & Fujita, M. & 7.6 \\
\hline $\begin{array}{l}\text { Eberlein, D. } \\
\text { Ebilıara, D. }\end{array}$ & $4.5,5.7$ & Fujiwara, $S$. & $\begin{array}{l}4.4,4.5,4.6,5.1, \\
7.2,7.3\end{array}$ \\
\hline Eck, M. G. & 3.10 & Fukase, S, & 3.5 \\
\hline Eggleton, P.L. & 3.6 & Fukumoto, Y. & 4.6 \\
\hline Eikermann, J. & 5.8 & Furuhashi, T. & 11.2 \\
\hline El-Antably, A.M. & 5.4 & Furukawa, T, & 5.4 \\
\hline Ema, $S$ & 6.3 & Furuta, Y. & $\begin{array}{l}10.2,10.3,10.4 \\
11.1\end{array}$ \\
\hline Eno, $S$. & 3.5 & Gaede, P. J. & $3.8,5.3,5.4$ \\
\hline Enokuchi, M. & 9.2 & Gavilyuk, V. A. & 4.2 \\
\hline Ensing, H. J. & 10.3 & Geduhn, N. & 8.4 \\
\hline Fife, A. A. & $3.8,10.2,10.3$ & Genest, B. A. & 2.3 \\
\hline Fink, H. J. & 4.2 & Gentile, G. & 5.6 \\
\hline Fintescu, N. D. & 5.5 & Gibbon, M. A. & 5.5 \\
\hline Fitzpatrick, C. & 9.1 & Gibson, J. & 8.1 \\
\hline Flowers, C. A. & 14.1 & Giaras I F & $44,54,55,57$ \\
\hline Flynn, T. M. & 10.3 & Gieras, J, $\Gamma$ & $4.4, \ldots, 4, \ldots, \ldots, \ldots, 1$ \\
\hline Fombrum, C. & 4.2 & & \\
\hline Freeman, E. M. & 5.1 & Ginlies, G. 1. & 2.3 \\
\hline Friedrich, R. & $\begin{array}{l}5.4,5.6,5.8 \\
11.1,11.2\end{array}$ & $\begin{array}{l}\text { Gilliland, R. G. } \\
\text { Giovachini, J.L. }\end{array}$ & $\begin{array}{l}5.5,6.2,6.3 \\
5.3\end{array}$ \\
\hline
\end{tabular}


Glatzel, K.

$3.4,3.5$

Goodall, R, M.

$3.3,8.1$

Gottzein, E.

$2.2,8.1$

Grunwuld, $\mathrm{H}$.

Guckel, H.

Guderjatın, C, A.

Guenther, C. R.

Guillemette, R.

Habercom, G. E.

Hamburg, J, R.

Hara, H.

Hariyama, T.

Harman, R. J.

Harrison, J.

Hartmann, P.

Hasegawa, $Y$.

Hashimoto, F.

Hayafune, K.

Hayashi, K.

Hayashi, T.

Hayden, J. T.

Hayes

Hayes, W. F.

He, J.L.

Hebler, $\mathrm{H}$.

Heinrich, K.
11.1

8.3

10.1

8.1

4.2

3.5

1.3

9.2

4.4

1.2

1.1

3.10

1.1

8.4

7.6

10.1

8.2

4.1

3.8

$2.2,3.4,3.6$, $3.11,6.3,7.5$, $9.1,14.1$

12.1

1.2

3.9
Herai, ' $T$.

Hessler, H.

Higucht, $\mathrm{T}$,

Hikasa, Y.

Hikihara, T.

Hirane, $Y$.

8.4

Hirao, $Y$.

8.4

Hirata, T.

8.4

Hobara, $\mathrm{T}$.

3.3

Hochhueusler, P.

7.5

Hogan, J, R.

4.2

Holtz, J.

8.1

Homer, G. J.

4.2

Hoppie, L. O.

$1.1,2.1,4.1$

Hoshino, A.

1.4

Hoshino, $\mathrm{H}$.

9.2

Hosoda, Y.

$3.6,3.7,3.9$, $3.10,3.11,5.4$, 7.5

Howell, J. P.

7.1

Hrovat, D.

4.3

Hubbard, M.

4.3

Hull, J. R.

Hunt, T. K.

$1.4,4.5,10.2$ 10.3

4.1

Hupe, $\mathrm{H}$.

4.6

Huss, H. W.

1.3

Igushi, M. 


\begin{tabular}{|c|c|c|c|}
\hline \multirow[t]{2}{*}{ Ikeda, H. } & $\begin{array}{l}6.3,8.3,8.4 \\
11.1,11.2^{2}\end{array}$ & Kakurai, M. & 9.2 \\
\hline & - & Kanazawa, $\mathrm{H}$. & 5.7 \\
\hline $\mathrm{Im}, \mathrm{D} . \mathrm{H}$ & 5.7 & Kanda, S. & $1.3,6.3,8.3$ \\
\hline Imagawa, K. & 4.5 & Karita, J. & 5.7 \\
\hline Inoue, $\mathrm{M}$. & 5.7 & Kato, J. & $3.7,4.4$ \\
\hline Ishida, M. & 11.2 & Kato, S. & 13.1 \\
\hline Ishiguro, A. & 11.2 & Kato, $\mathrm{T}$. & $3.7,5.7$ \\
\hline Ishiyama, A. & 5.7 & Katsan, T. I. & 7.3 \\
\hline Ishizu, S. & 11.2 & Katz, R. M. & $5.3,6.1,6.2$ \\
\hline Ishizuka, H. & 1.2 & Kavanagh, R. J. & 8.1 \\
\hline Iwahana, T'. & $\begin{array}{l}4.2,4.3,5.7,6.1 \\
10.4\end{array}$ & Kawaguchi, I. & $8.3,8.4$ \\
\hline Iwamoto, $\mathrm{M}$. & 6.1 & Kawakami, T. & 13.1 \\
\hline Iwasa, Y. & $7.3,10.1$ & Kawakatsu, H. & 5.7 \\
\hline Iwawaki, S. & 11.1 & Kawanishi, T. & $5.7,8.3$ \\
\hline Iwaya, M. & $\begin{array}{l}3.7,3.11,4.4 \\
7.5,7.7,9.2\end{array}$ & Kawashima, M. & $\begin{array}{l}3.6,3.7,3.9 \\
3.10,3.11,4.4 \\
4.5,5.4,7.5\end{array}$ \\
\hline Jackson, J. W. & 4.1 & Keith, R. W. & 1.3 \\
\hline Jain, O.P. & 4.3 & Khurdok, G. & 3.4 \\
\hline Jansen, H. & 13.1 & Kikuchi, S. & 1.1 \\
\hline Jansen, Ing. H. & 13.1 & $\mathrm{Kim}, \mathrm{G}, \mathrm{T}$. & 5.7 \\
\hline Jayawant, B. V. & $\begin{array}{l}2.2,3.3,4.3,4.5 \\
7.2\end{array}$ & Kim, K. I. & $3.3,7.2$ \\
\hline Jizo, Y. & $10.1,10.2,10.4$ & Kimura, $\mathrm{H}$. & 9.2 \\
\hline Johnson, L. R. & 1.4 & Kishimoto, S. & 9.1 \\
\hline Johnson, R. B. I. & 9.1 & Kitamoto, M. & $3.7,4.4,5.4$ \\
\hline Joyce, $\mathrm{H}$. & 9.2 & Kiwaki, H. & $4.6,5.7$ \\
\hline Kaga, S. & 11.2 & Kneuer, R. & 9.2 \\
\hline
\end{tabular}




\begin{tabular}{|c|c|c|c|}
\hline Knigge, R. & 8.4 & Leondes, C. 'T. & 8.1 \\
\hline Kobayashi, S. & $4.6,7.7$ & Leonhard, W. & $3.4,5.2$ \\
\hline Kochetkov, V. M. & $4.3,7.3,7.5$ & Levi, E. & 5.1 \\
\hline Koga, S. & 8.3 & Leyrit, M. & 5.3 \\
\hline Kohyama, $\mathrm{H}$. & 5.7 & Limbert, D. A. & $7.1,7.2$ \\
\hline Koike, S. & $8.2,11.1$ & Linder, D. & 3.3 \\
\hline Kolm, H. H. & $2.1,2.2$ & Lingaya, $S$, & $5.2,8.1$ \\
\hline Kortuem, W & $7.4,8.2$ & Lowther, D. A. & $5.1,12.1$ \\
\hline Kortum, W. & 7.6 & Mahtani, J, L. & $4.4,5.1,6.2,7.5$ \\
\hline Koseki, T. & $4.5,5.7$ & Mahrer, K. D. & 3.1 \\
\hline Kotb, M. & 7.4 & Maki, N. & 4.6 \\
\hline Kozachenko, E. V. & 6.3 & Mandt, $\mathrm{K}$. & 8.1 \\
\hline Kraft, K. H. & 8.3 & Margolls, D. L. & 4.3 \\
\hline Kraus, H. G. & 1.4 & Masada, E. & $1.2,3.7,3.8,3.9$ \\
\hline Kretzschrnar, R. & 1.4 & & $7.5,7.6,8.2,8.3$ \\
\hline Kuprianov, Y, V. & 6.3 & Matin, V. I. & $3.3,7.5$ \\
\hline Kurosawa, K. & 10.3 & Matsui, K. & 8.2 \\
\hline Kusunoki, K. & 7.5 & Matsumaru, $\mathrm{H}$. & 8.2 \\
\hline Kuwahara, Y. & 9.1 & Matsumoto, A. & 11.2 \\
\hline Kuzuu, T. & $3.1,7.1$ & Matsumura, F. & 7.6 \\
\hline \multirow[t]{2}{*}{ Kyotani, Y. } & \multirow{2}{*}{$\begin{array}{l}2.1,2.3,3.1,3.2 \\
3.4,3.5,3.9 \\
3.11\end{array}$} & Matsunuma, S. & 7.7 \\
\hline & & Matsuoka, K. & 8.2 \\
\hline Lang, $A$. & 5.3 & Matsuura, A. & 9.2 \\
\hline Law, C. E. & 3.2 & May, H. & $4.4,4.6,5.2,6.2$ \\
\hline Lawton, A. P. & 9.1 & Mayer, W. J. & 3.11 \\
\hline Lebedev, V. G. & 7.3 & Mclean, G. W. & 5.6 \\
\hline Leistikow, R. & $\begin{array}{l}5.4,5.6,11.1, \\
11.2\end{array}$ & Meins, J. & 3.11 \\
\hline
\end{tabular}




\begin{tabular}{|c|c|c|c|}
\hline Meisinger, R. & $2.2,7.3,8.2$ & Muhlenberg, J. D. & 6.1 \\
\hline Melville, P. H. & 5.1 & Mulhall, B. E. & $2.2,5.1,6.2,7.1$ \\
\hline Menden, W. & $3.10,3.12$ & Murai, M. & $3.9,3.10,11.2$ \\
\hline Merklinghaus, W. & 3.9 & Murai, T. & $4.5,8.3$ \\
\hline Middleton, W. D. & 3.4 & Mustow, S. N. & 3.7 \\
\hline Mihirogi, K. & 3.7 & Muta, $\mathrm{H}$. & 8.3 \\
\hline Mikirtichev, A. A. & $3.3,7.2$ & Mytarev, A. I. & 7.3 \\
\hline Miller, L. & $\begin{array}{l}2.2,3.8,3.10 \\
3.11\end{array}$ & Nagai, $M$. & $7.3,7.6,8.4$ \\
\hline & & Nagaike, $\mathrm{T}$. & 3.12 \\
\hline Milner, J. L. & 7.1 & Nagaoka, $\mathrm{H}$ & 3.5 \\
\hline Mirzamani, $\mathrm{S}, \mathrm{J}$ & 7.5 & Nagata, K. & 11.2 \\
\hline Mita, $\mathrm{H}$ & 10.1 & Nagayama, $Y$. & 7.7 \\
\hline Miura, S & 9.1 & Nakagawa, M. & 14.1 \\
\hline Miyamoto, M. & $7.3,8.3,9.2$ & Nakagawa, $\mathrm{T}$. & $7.5,7.6,8.2,8.3$ \\
\hline Miyashita, I. & 11.2 & Nakajima, $\mathrm{O}$. & 5.6 \\
\hline Miyashita, K. & $4.6,5.7$ & Nakamichi, Y. & $6.3,11.1$ \\
\hline Miyazaki, K. & 3.5 & Nakamura, $\mathrm{K}$ & 8.2 \\
\hline Mizuma, T. & 11.2 & Nakamura, $\mathrm{N}$. & 3.5 \\
\hline Mnich, P. & 13.1 & Nakamura, S. & 3.5 \\
\hline Mohdulla, A. U. & 4.2 & Nakanishi, K. & $7.5,8.3$ \\
\hline Money, L. J. & 2.3 & Nakao, A. & 10.2 \\
\hline Moon, F. & 7.2 & Nakao, H. & 10.3 \\
\hline Moon, F. C. & 7.4 & Nakashima, H. & $10.1,10.2,10.4$ \\
\hline Moran, A. & 7.6 & Nakashima, N. & 3.5 \\
\hline Morishital, M. & $4.6,6.3,8.3$ & Nakashima, $\mathrm{O}$ & 7.6 \\
\hline Morita, T. & 2.3 & Namikaw'a, $\mathrm{H}$. & 3.7 \\
\hline $\begin{array}{l}\text { Mosebach, H. } \\
\text { Mueller, P. C. }\end{array}$ & $\begin{array}{l}5.2,6.1 \\
8.2\end{array}$ & Nasar, S. A. & 3.11 \\
\hline
\end{tabular}




\begin{tabular}{llll} 
Nemoto, K. & 10.3 & Omel'Yanenko, V. I. & 10.1 \\
Nene, V. D. & 6.1 & Ong, R. & 5.4 \\
Nicolas, A. & 10.3 & Ono, J. & 3.7 \\
Nihei, H. & 5.7 & Onuki, T. & $4.5,5.7,8.3$ \\
Nikolaeva, N. S. & 4.3 & Ooi, B. T. & $4.1,4.3,9.1$ \\
Ninagawa, Y. & 10.3 & Oraee Mirzamani, S. J. & 7.4 \\
Nishi, N. & 11.1 & Oraee Paul, R. J. A. & 7.5 \\
Nishiki, T. & 9.2 & Oshima, K. & 10.1 \\
Niwa, T. & 9.1 & Oshinoya, Y. & 8.4 \\
Nonaka, S. & $5.3,5.4,5.5,5.5$ & Otsubo, T. & 8.2 \\
Norris, G. A. & $5.7,7.6,12.1$ & Otsuka, K. & 1.4 \\
North, B. H. & 1.1 & Outake, T. & 11.1 \\
Numata, H. & 9.2 & Ozaki, Y. & 7.6 \\
Oberretl, K. & 5.7 & Palmer, J. D. & 3.4 \\
Oda, K. & 5.3 & Papusoiu, G. & 3.11 \\
Ogawa, K. & 13.1 & Park, E. C. & 5.7 \\
Ogiwara, H. & 12.1 & Parker, J. H. & 5.5 \\
Ohguma, H. & $7.2,10.1$ & Parnitzke, R. A. & 3.6 \\
Ohira, Y. & 10.2 & Parsch, C. P. & 5.2 \\
Ohishi, A. & 8.3 & Pascal, J. P. & $3.11,5.3,5.5$ \\
Ohmori, Y. & 3.11 & Paul, R.J. A. & $4.4,7.4$ \\
Ohnishi, K. & 11.2 & Pavlyukov, V. M. & 6.3 \\
Ohsaki, H. & 8.2 & Peabody, F. & 5.5 \\
Ohtsuka, T. & $5.7,11.3$ & Pearson, G. W. & 5.5 \\
Okada, K. & $3.2,10.1$ & Persch, C. P. & 5.2 \\
Okamoto, H. & 10.1 & .1 \\
Okuma, S. & 7.1 & & 7.3 \\
\hline
\end{tabular}




\begin{tabular}{|c|c|c|c|}
\hline Polifka, F. & 1.2 & Ruoss, W. & 3.11 \\
\hline Polifka, P. & $1.4,3.7$ & Ruppel, J. & 5.8 \\
\hline Pollard, M. G. & $2.3,3.6,3.8$ & Sabonnadiere, J. C. & 12.1 \\
\hline Pons, R. L. & 6.1 & Saijo, $\mathrm{T}$. & $5.5,11.1$ \\
\hline Popp, K. & 7.3 & Saito, R. & $4.6,10.1$ \\
\hline Powell, J. R. & $2.1,4.1,6.1$ & Saitoh, T. & 4.6 \\
\hline Rabinovich, B. I. & 7.3 & Sakaguchi & 9.2 \\
\hline Rakels, J. H. & 6.2 & Sakamoto, $\mathrm{T}$. & 12.1 \\
\hline Ranawake, U.A. & 5.6 & Samaha, M. & 7.4 \\
\hline Randle, T. C. & 4.2 & Sanders, D. B. & 2.3 \\
\hline Raschbichler, H. G. & $1.4,3.10,9.2$ & Sanker, T. S. & 7.4 \\
\hline Ravera, R. J. & 6.1 & Sasaki, M. & 3.6 \\
\hline Reimberr, G. W. & 10.1 & Sasaki, T. & 8.4 \\
\hline \multirow[t]{2}{*}{ Reitz, J. R. } & \multirow{2}{*}{$\begin{array}{l}1.1,2.2,3.1,3.2, \\
4.1,4.2,6.1 \\
10.1\end{array}$} & Sato, Y. & $1.1,9.1,9.2$ \\
\hline & & Sattler, P. K. & 12.1 \\
\hline Rentmeister, M. & 5.3 & Sawada, Y. & 8.4 \\
\hline Renzhin, G. I. & 7.3 & Scarano, M. & 5.6 \\
\hline \multirow[t]{2}{*}{ Rhodes, R.G. } & \multirow{2}{*}{$\begin{array}{l}2.2,3.4,3.6,4.1 \\
4.4,5.1,6.2,7.1 \\
7.5\end{array}$} & Schieber, D. & 6.2 \\
\hline & & Schiehlen, W. O. & 7.4 \\
\hline Ribbentrop, R. & $1.3,1.4$ & Schmelz, R. E. & 1.3 \\
\hline Richardson, H. H. & $7.1,7.2$ & Schmitt, A. & 1.1 \\
\hline Riches, E. E. & $3.8,3.9$ & Schnieder, E. & $8.1,8.3,8.4$ \\
\hline Rodger, D. & $4.4,5.6$ & Schulz, H. & $3.4,3.5$ \\
\hline Rogg, D. & $1.1,3.4,3.5,3.9$ & Schwalm, C. L. & 6.2 \\
\hline Rote, D. M. & $1.4,12.1$ & Schwier, C. & $1.1,1.3$ \\
\hline Rotondale, N. & 5.6 & Schwindt, $G$ & $3.9,9.2$ \\
\hline Rudback, N. E. & $3.4,3.8$ & Seki, A. & $1.4,11.3,13.1$ \\
\hline
\end{tabular}




\begin{tabular}{|c|c|c|c|}
\hline Sekimoto, $\mathrm{H}$. & 11.2 & Tada, N. & 9.2 \\
\hline Shapovalenko, A. G. & 4.2 & Takabayashi, Y. & 7.6 \\
\hline Shibata, M. & 4.6 & Takada, N. & 11.1 \\
\hline Shimada, K, & $4.4,8.3$ & Takada, T. & 3.7 \\
\hline Shimada, $\mathrm{T}$. & 4.4 & Takagi, N. & 3.7 \\
\hline Shimizu, M. & 7.6 & Takagi, S. & 1.3 \\
\hline Shimogo, $\mathrm{T}$. & 8.4 & Takagi, $\mathrm{T}$. & $3.7,8.3$ \\
\hline Shiraishi & 6.3 & Takahashi, H. & 3.5 \\
\hline Shoyama, Y. & 3.7 & Takahashi, T. & 4.3 \\
\hline Silvester, P. P. & 12.1 & Takakado, Y. & 5.7 \\
\hline Simomae, $\mathrm{T}$. & 11.3 & Takakura, M. & 7.3 \\
\hline Singleton, R. C. & 4.1 & Takano, I. & 7.2 \\
\hline Sinha, P. K. & $\begin{array}{l}2.3,4.3,6.2,7.2 \\
7.5,8.1,8.4\end{array}$ & $\begin{array}{l}\text { Takano, } \mathrm{N} \text {. } \\
\text { Takata, T. }\end{array}$ & $\begin{array}{l}7.2 \\
3.10\end{array}$ \\
\hline Skalski, C. A. & 6.1 & Takatsuka, H. & 3.12 \\
\hline Slemon, G. R. & $3.2,5.1,5.2$ & Takeda, $\mathrm{H}$ & 3.3 \\
\hline Sokolov, Y. D. & 7.3 & Takei, H. & 11.2 \\
\hline Sone, S. & 11.1 & Takeshita, K. & 9.1 \\
\hline Staeheli, G. A. & 2.2 & Takeuchi, H. & 5.4 \\
\hline Steinmetz, G. & $3.7,3.8,4.5$ & Tamura, M. & $1.2,11.3$ \\
\hline Stephan, A. & 9.2 & Tamura, N. & $6.3,8.3$ \\
\hline $\begin{array}{l}\text { Stockl, R. } \\
\text { Suslova, K. N. }\end{array}$ & 11.2 & Tanaka, $\mathrm{H}$. & $\begin{array}{l}2.3,3.7,3.8,3.9 \\
3.10\end{array}$ \\
\hline Suzuki, K. & $11.1,11.2$ & Tanaka, S. & 7.6 \\
\hline Suzuki, S. & $\begin{array}{l}3.6,3.9,3.10 \\
4.4,7.5,11.1\end{array}$ & $\begin{array}{l}\text { Tanida, } T \text {. } \\
\text { Tanno, } Y\end{array}$ & 3.6 \\
\hline Suzuki, T. & 4.5 & Tatsumi, T. & 11.1 \\
\hline Iwahana, $\mathrm{l}$. & 4.2 & Terada, $\mathrm{K}$. & 3.5 \\
\hline
\end{tabular}




\begin{tabular}{|c|c|c|c|}
\hline Terada, M. & 3.5 & Usami, Y. & 3.1 \\
\hline Terasaki, M. & 10.2 & Utzt, A. & 7.4 \\
\hline Terauch, N. & 10.3 & Van Dalen, K. & 9.1 \\
\hline Terauchi, N. & 4.5 & Vasil'ev, S. V. & $3.3,7.2$ \\
\hline Terzis, N. & 5.2 & Voevodskii, K. E. & 7.3 \\
\hline Thompson, L. S. & 2.3 & Wackers, M. & $1.2,1.4,3.10$ \\
\hline Thornton, R. D. & $2.1,2.2,6.1$ & Wada, T. & 10.2 \\
\hline Tillotson, M. & 10.3 & Wallace, A. K. & 5.6 \\
\hline Toda, $\mathrm{H}$. & 6.3 & Wallrapp, O. & 8.2 \\
\hline Torii, S. & 11.3 & Walters, C. R. & 4.2 \\
\hline Tozoni, O. V. & 4.3 & Wan, C. C. & 4.2 \\
\hline Treshchev, I. I. & 4.3 & Wang, $\mathrm{Z}$. & 12.1 \\
\hline Trica, A. & 3.11 & Watanabe, $\mathrm{T}$. & 5.7 \\
\hline Tsuchishima, H. & $4.6,10.3$ & Weh, $\mathrm{H}$. & $\begin{array}{l}2.4,4.1,4.4,4.6 \text {, } \\
5.2,5.3,6.1\end{array}$ \\
\hline Tsuhamoto, $\mathrm{O}$. & 7.3 & Weller, A. & 5.4 \\
\hline $\begin{array}{l}\text { Tsujioka, Y. } \\
\text { Tucker H. G }\end{array}$ & 7.6 & Westera, W. & 10.3 \\
\hline Turton, R. A. & 5.1 & $\begin{array}{l}\text { Wiegner, G. } \\
\text { Wienenga, P. }\end{array}$ & $\begin{array}{l}5.2 \\
11.1\end{array}$ \\
\hline Twahana, $\mathrm{T}$. & 7.1 & Wilkie, D. F. & $1.1,4.1,6.1,7.1$ \\
\hline Tyurin, Y. V. & 7.4 & Williams, J. T. & 4.4 \\
\hline Ueno, $T$. & 12.1 & Willigens, J. M. & 1.4 \\
\hline Umemori, T. & 8.2 & Wilson, M. N. & 4.2 \\
\hline Uher, R. A. & 1.3 & Wipf, S. L. & 2.2 \\
\hline Uno, $\mathrm{M}$. & 1.4 & Wormley D N & 7179 \\
\hline Urankar, L. & $4.2,7.2$ & Yahung $\mathrm{H}$ & 76 \\
\hline Usichenko, Y. G. & 10.1 & Ýamadia, T'. & 6.1 \\
\hline
\end{tabular}


Yamaguchi, $\mathrm{H}$.

Yamaji, H.

Yamaji, M.

Yamamiya, M.

Yamamura, $\mathbf{S}$.

Yamamura, $\mathrm{T}$.

Yamaoka, S.

Yamashita, $\mathrm{H}$.

Yashiro, M.

Yatsu, S.

Yohida, $\mathrm{K}$.

Yokoi, T.

Yokoyama, $\mathrm{T}$.

Yoshida, $\mathrm{K}$.

Yoshimura, M.

Yoshioka, $\mathrm{H}$.

Yoshizawa, M.

Yudakov, Y. V.

Zicha, J. H.

Zukin, P. P.
$4.4,4.5,5.7,6.3$

10.2

$10.2,10.3$

9.2

$3.2,4.4,4.5,3.7$,

$6.3,7.5,8.2,8.3$

5.7

11.1

$3.4,6.1$

5.7

8.2

$5.6,7.6$

5.7

$1.3,6.3,8.3$

$7.3,7.6,8.3$

13.1

9.2

7.6

4.3

3.8

4.2 

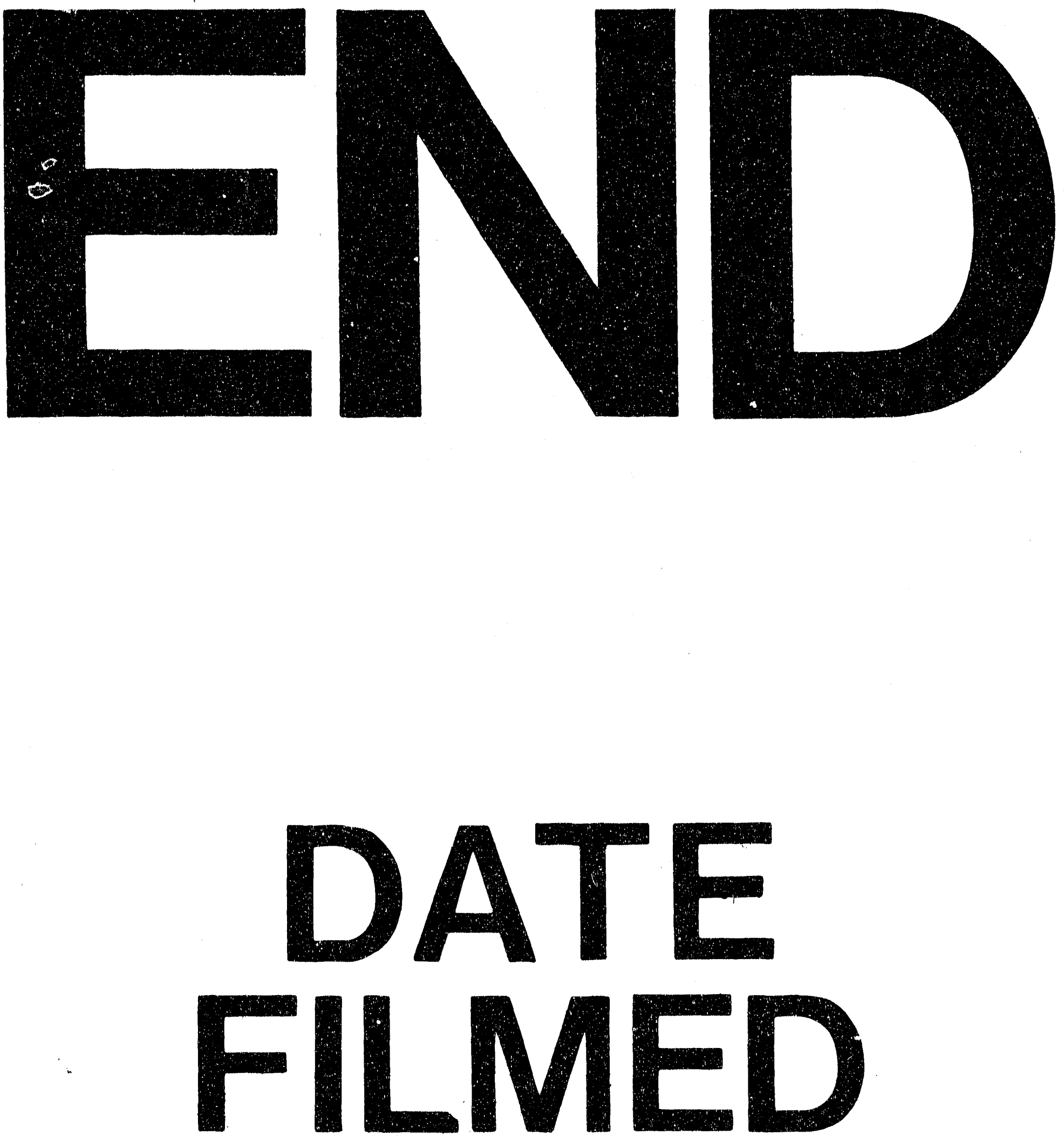

I
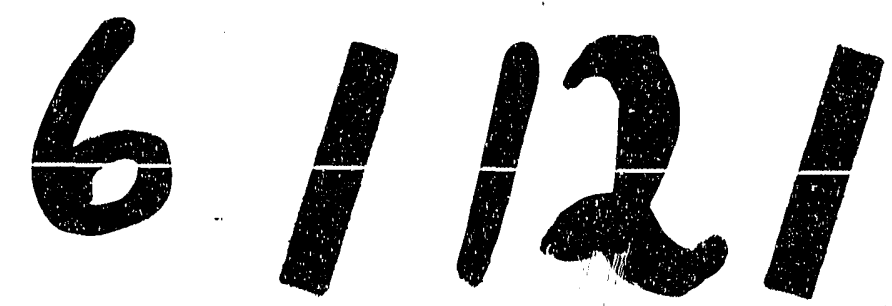

92 
